\title{
Folk-song to formal performance: Interpreting the songs of Jean Ritchie for voice recital
}

Julianne E. Laird

West Virginia University, jel0025@mix.wvu.edu

Follow this and additional works at: https://researchrepository.wvu.edu/etd

Part of the Music Performance Commons

\section{Recommended Citation}

Laird, Julianne E., "Folk-song to formal performance: Interpreting the songs of Jean Ritchie for voice recital" (2019). Graduate Theses, Dissertations, and Problem Reports. 7473.

https://researchrepository.wvu.edu/etd/7473

This Dissertation is protected by copyright and/or related rights. It has been brought to you by the The Research Repository @ WVU with permission from the rights-holder(s). You are free to use this Dissertation in any way that is permitted by the copyright and related rights legislation that applies to your use. For other uses you must obtain permission from the rights-holder(s) directly, unless additional rights are indicated by a Creative Commons license in the record and/ or on the work itself. This Dissertation has been accepted for inclusion in WVU Graduate Theses, Dissertations, and Problem Reports collection by an authorized administrator of The Research Repository @ WVU.

For more information, please contact researchrepository@mail.wvu.edu. 
Folk-song to formal performance:

Interpreting the songs of Jean Ritchie for voice recital

Julianne Laird

Doctoral Document submitted to

The College of Creative Arts

At West Virginia University

In partial fulfillment of the requirements for the degree of

Doctor of Musical Arts in

Voice Performance

Hope Koehler, D.M.A., Chair

William Koehler, D.M.A.

Matthew Heap, Ph.D.

General McArthur Hambrick, M.F.A.

School of Music

Morgantown, West Virginia

2019

Keywords: Jean Ritchie; Appalachia; Protest Song; Folk-song; Art-song; Folk-music;

Voice Recital; American Folk-Revival; traditional music; Harkers Island; Nell Cropsey;

Ivey Scott

Copyright 2019 Julianne Laird 


\section{ABSTRACT \\ Folk-song to formal performance: Interpreting the songs of Jean Ritchie for voice recital}

\section{Julianne Laird}

The purpose of this study was to identify the value of incorporating American folk-song into a formal voice recital program, specifically the collections and compositions of Jean Ritchie. This qualitative study identified criteria for choosing specific folk-songs to include in formal recital, assessed quality in a folk-song arrangement, discussed suitable instrumentation for accompaniment, and suggested appropriate performance practices for concert performance. New folk-song literature was discovered through accessing original unpublished sources in the American Folklife Center of the Library of Congress. Finally, a format and program for incorporating the collected and composed folk-songs of Jean Ritchie in formal recital was developed. It was determined that American folk-song continues to be a valuable source of literature for the art-song repertoire. While much of the folk-song literature remains to be arranged for formal recital, folk-songs can be discovered, arranged, and performed in recital, remaining true to the original intention of the composer, thus diversifying, enriching, and enhancing the art-song repertoire. 


\section{ACKNOWLEDGEMENTS}

It has been an honor and a privilege to have the opportunity to complete my doctoral studies at West Virginia University. The faculty and staff of the School of Music, the Creative Arts Center, and West Virginia University have gone above and beyond to assist me in my work, and to all - professors, administrative associates, technical coordinators, and custodial staff - I offer my heartfelt thanks.

There are certain individuals who have been especially valuable to me through their generous contributions of expertise throughout my tenure at WVU. It is with the deepest gratitude that I acknowledge the following:

Dr. Hope Koehler, Research Advisor, Chairman of the Voice Faculty, and my studio teacher Professor Cynthia Anderson, Director of Graduate Studies

Professor James Kenon Mitchell, Director of Opera and Coach Accompanist

Jamie Whoolery, Director of Production and Facilities, Creative Arts Center

Jodie Lewis, Administrative Associate

R.J. Nestor, Composer of original arrangements for this study

Dr. Hope Koehler, Dr. William Koehler, Dr. Matthew Heap, and Professor General McArthur Hambrick, members of my doctoral committee

Finally, to my "team":

Words cannot express my eternal gratitude for your love, time, financial support, proofreading, counsel, and wisdom:

My husband, Richard T. Workman

and my parents, Dr. David H. Laird and Nancy S. Laird

Soli Deo gloria 


\section{Table of Contents}

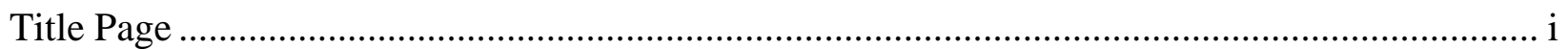

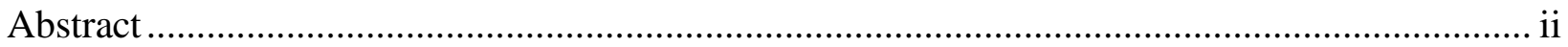

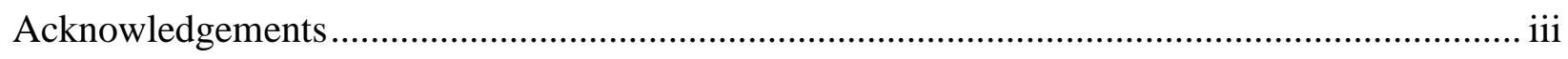

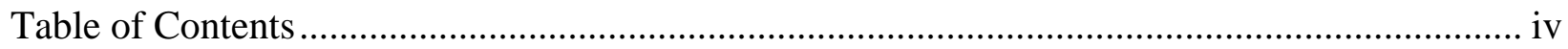

Chapter 1:

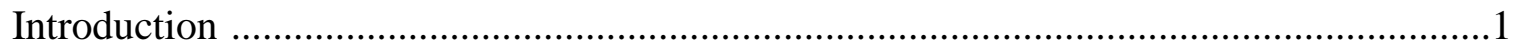

Chapter 2:

Jean Ritchie $(1922-2015)$ : a brief biography ................................................... 9

Chapter 3:

The role of American folk-song in formal recital ........................................................18

Chapter 4:

Identifying specific songs of Jean Ritchie for formal recital ......................................39

Chapter 5:

The Ritchie-Pickow 1951 tour of Eastern North Carolina.............................................60

Chapter 6:

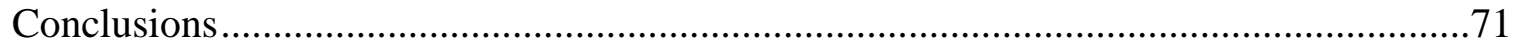

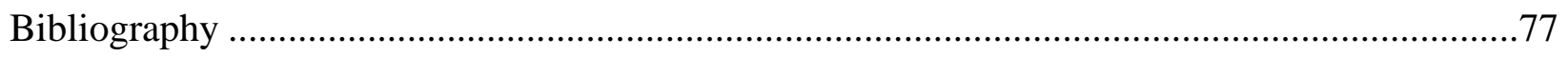

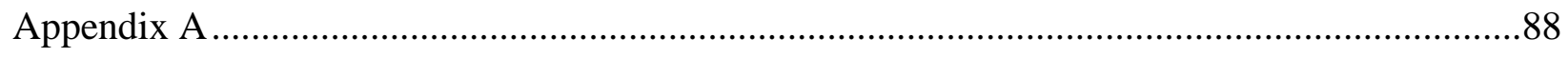

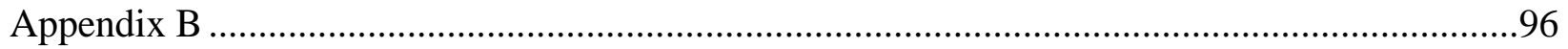

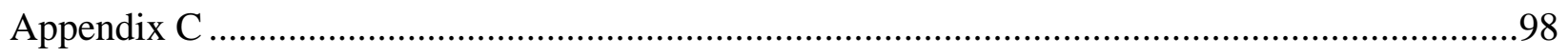

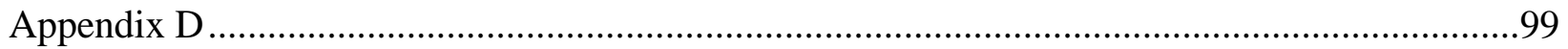

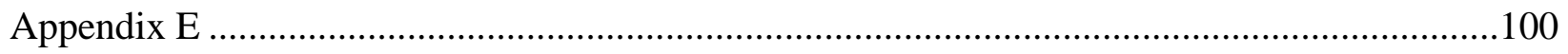




\section{Folk-song to formal performance: \\ Interpreting the songs of Jean Ritchie for voice recital}

\section{CHAPTER 1 \\ Introduction}

"Where has it gone, all the beautiful music of our grandparents...?" shouts a cartoon featuring three old-timers playing music on folk instruments in the living room of a home. ${ }^{1}$ I have the unique pedigree of descending from grandparents on both sides of my family who were musicians. My paternal grandmother was a Lutheran church organist; my fun-loving maternal grandfather was a self-trained musical artist in the popular styles of the fin-de-siècle, a skilled amateur pianist, cornetist, and dance teacher. This musical legacy was treated in our home with admiration and respect. We didn't know these grandparents, but as children we were drawn to music, never expecting that we would all have careers as professional musicians and music educators. However, following in the footsteps of those who went before us, my two siblings and I have embraced both formal and popular styles of music-making,

Singing has always been my passion, but as a child it was unfathomable that formal singing would become my destiny. As a teenager I immersed myself in the music that spoke to me the loudest: music of the American Folk-Revival that I heard on the radio in the late 1960s. When I went to college to study music education, I wept through my earliest voice lessons: I thought I was studying to be a folk-singer. My voice teacher kindly explained that I would be singing literature labeled "Western art song." The college choral professor informed me that now I would never be playing guitar while I sang and scoffed at my interest in folk music. I had

\footnotetext{
${ }^{1}$ R. Crumb, “Beautiful Music," Pinterest, Accessed November 28, 2018), https://www.pinterest.ca/pin/279926933059656929/.
} 
never enjoyed hearing anyone sing in "classical” styles, and it wasn't until much later that I knew my voice was better suited for formal singing. I soldiered on through my music education degree and began to teach in the public schools. I worked to develop links between the popular music my students enjoyed, the Appalachian music of the local community heritage, and Western art music. Through this journey, I became acquainted with the music of song collector and composer Jean Ritchie.

I was privileged to attend a concert that Ritchie and her sons presented in Frostburg, Maryland, in late summer 2009, just a few months before she suffered the debilitating stroke that ended her performing career. It was a thrill to hear this national treasure perform, and I will never forget the experience. I became curious as to whether her collections and compositions could be adapted for formal singing.

When I began my sabbatical year studying at West Virginia University, I learned that American folk music could be particularly relevant to teaching young singers. These songs generally had comfortably limited ranges, consistent step-wise melodic motion, and accessible harmonic frameworks. I heard American folk songs performed often in voice recitals. The voice professors assigned folk music in their studios and were experts in interpreting folk music for recording and concert performances. Making a connection between the folk music of Jean Ritchie and the interpretation of this music for formal recital now became a challenge. 


\section{Statement of the Topic}

In this research document I will discuss the history and value of using folk-song in formal recital. I will specifically focus on the merit of enhancing the art-song repertoire through including folk-songs from the collections and compositions of Jean Ritchie. Using scholarly research and past practices, I will develop criteria for choosing folk-songs for performance, identifying quality in a folk-song arrangement, and choosing instrumentation for appropriately accompanying folk-song as art-song. Finally, I will discuss performance practices unique to the presentation of folk-song which connect folk-song literature to today's students and audiences.

An important component of my research took me to the American Folklife Center at the Library of Congress which acquired the collected works of Jean Ritchie and George Pickow in 2008. There I discovered unpublished folk songs that Ritchie and Pickow collected while touring coastal North Carolina in 1951. My husband and I live on the Outer Banks of North Carolina in the summers and perform music of the coastal traditions. For this reason, I sought to find songs from this collection to include not only on my formal recital but also to share with the visitors to our beautiful coastal region.

As a result of this research I will present a format, following criteria gleaned from the literature, for incorporating the music of Jean Ritchie in a formal voice recital. Songs from Ritchie's traditional collections, original compositions, and the 1951 tour of coastal North Carolina will be included in the suggested program for recital.

\section{Jean Ritchie}

Jean Ritchie (1922 - 2015) was one of the foremost collectors of Southern Appalachian and British Isles folk music in the world. Born into a large, poor, God-fearing family in Eastern Kentucky, she realized as a young girl that she had the potential to influence the world. Even as 
an elementary student she studied her ancestry and heritage and made that study a part of her life's work. College-educated, she was awarded a Fulbright scholarship in 1952 to travel to the British Isles to continue her folk-song studies and was revered in the folk-song revolution of the sixties, ${ }^{2}$ noted for her collaborative performances with musicians including Pete Seeger, Woody Guthrie, and Doc Watson. In addition to the folk songs that she collected, she composed her own songs as an important figure in the American Folk-Revival, sometimes under the pseudonym “'Than Hall.” She was an authority on Appalachian dulcimer technique and composed several books on the topic. She has often been identified as the "Mother of Folk."3

\section{Review of the Literature}

The progress of computer technology has opened many new doors to discovering the literature available for use in a study of this nature. My initial study on the literature available on this topic resulted in an annotated bibliography compiled in 2016. That document, titled Jean Ritchie: Collected and Composed Songs and Arrangements Suitable for Formal Voice Recital, An Annotated Bibliography, can be found as Appendix A in this thesis. However, since preparing that annotated bibliography, many new sources of information have become available to me.

In 2008, Jean Ritchie and George Pickow gifted the entirety of their collected works to the American Folklife Center of the Library of Congress. This collection was updated in 2015 upon Jean's passing. Over 70,000 artifacts are included in this collection, consisting of magnetic

2Stephen Winick, “Jean Ritchie, 1922 - 2015,” Folklife Today, The Library of Congress, June 11, 2015, Accessed July 2, 2019, https://blogs.loc.gov/folklife/2015/06/jean-ritchie-1922-2015/.

3 Paul DeRienzo, “Jean Ritchie, 92, the Village's 'Mother of Folk,'” The Villager, June 18, 2015, Accessed July 2, 2019, https://www.thevillager.com/2015/06/jean-ritchie-92-the-villages-mother-of-folk/. 
tapes, photographs, set lists, lyrics, and other historical items. ${ }^{4}$ A Doctoral Student Dissertation Research and Travel Support Grant, offered by the Office of the Provost and the School of Music Graduate Committee, enabled me to travel to the American Folklife Center of the Library of Congress to research these original sources. While there I was privileged to work with the librarians, including Ritchie/Pickow archivist Marcia Segal, to discover recordings of unpublished songs and other artifacts that enriched my study. According to an AFC blog post by Segal, "Jean, as well as other members of her family, were diligent about keepsakes, and her correspondence is an archivist's dream. Most items include Jean's handwritten note about when she sent a response to an individual or organization. She kept careful records for most of her adult life, and her diligence in caring not only for her own records but for family treasures was a sharp reminder: make sure these people, and what they loved, are remembered."5

Another valuable source of information for this study has been Karen CarterSchwendler's 1995 doctoral dissertation on Jean Ritchie's life and work up to 1977. CarterSchwendler's analysis of Jean's role as a traditional performer and folk-song collector has served as an outstanding ethnographic resource.

YouTube videos and other sound and video media have proven to be important resources in this study. Hours invested in listening to Jean speak about her life and her life's work help one to reach back to former times and open up new cultural doors of understanding. This is especially helpful when developing a methodology for choosing folk-songs for formal recital.

${ }^{4}$ Library of Congress, Jean Ritchie and George Pickow collection, 1923 - 2015, Finding Aid. Washington, D.C.: Library of Congress, 2015, Accessed May 21, 2019, http://hdl.loc.gov/loc.afc/eadafc.af016008.

${ }^{5}$ Marcia Segal, "Gems from the Jean Ritchie and George Pickow collection," Folklife Today: American Folklife Collection and Veterans History Project, Library of Congress, July 3, 2017, Accessed May 21, 2019, https://blogs.loc.gov/folklife/2017/07/gems-from-the-jean-ritchie-george-pickow-collection/. 
Additionally, a collection of Jean Ritchie's musical recordings continues to reveal nuances in interpretation, informing choices made for instrumentation, accompaniment, and performance practices.

When seeking sources of information for re-interpreting folk-song as art-song, books and articles by and about singers and teachers of voice are extremely helpful. Older books and writings, though culturally distant from today's viewpoints, have proven to be quite beneficial. Information by or about noted collectors and composers such as Ruth Crawford Seeger and Percy Grainger inform this study by offering a historical background of quality and acclaim. Recent websites, weblogs, and publications, including those by the National Association of Teachers of Singing have proven to be especially useful when researching voice literature and performance practices.

\section{Research methodology:}

This study is based on qualitative research. The history and value of including American folk-song in formal recital will be explored. Historical data will be addressed in depth, including biographical information on the life and work of Jean Ritchie, the roots of southern Appalachian folk-music in the music of the British Isles, and the evolution of the American Folk-Revival. A methodology for adapting folk-song for formal recital, including criteria for choosing appropriate folk-songs, identifying quality in folk-song arrangements, suggestions for innovative accompaniments, and appropriate performance practices will be outlined with specific examples. Published and unpublished sources of musical literature will be discussed and referenced. An analysis of these sources of folk-song literature will result in a selection of songs from the 
Ritchie collection that could best be adapted for formal recital. New song literature procured from the Ritchie/Pickow collection of the American Folklife Center, specifically the 1951 tour of coastal North Carolina, will be discussed for the purposes of expanding the repertoire. Finally, a proposed recital program, gleaned from the resources outlined above, will be offered as a model for others to follow when developing a similar program.

\section{Anticipated conclusions:}

Our American folk-song heritage is both rich and diverse. It will be shown that there is great value in including this genre in concert performance. The unmatched historical and cultural wealth, inherent joy, and vocally fascinating contributions of American folk-songs make them especially valuable in formal recital. While many art-song arrangements of folk-songs exist, there are an abundance of songs that remain to be arranged and shared with new generations of singers and concertgoers. Facilitating new arrangements and settings of folksongs gleaned from the collections and compositions of Jean Ritchie will further diversify and expand the repertory for study and performance.

Through this research, criteria for choosing and arranging folk-songs for formal voice recital will be developed. Additionally, appropriate instrumentation and performance practices will be discussed. Using these standards, the analysis of published and unpublished sources of Jean Ritchie's folk-song collections and American Folk-Revival compositions will result in the selection and arrangement of songs for formal recital.

An overview of the life and work of Jean Ritchie will demonstrate the significance of her contributions to the study of Appalachian music and the music of the American Folk-Revival. Ritchie's commitment to understanding the value of her role as a song-collector, to seek the roots 
of her own heritage in the music of the British Isles, and to share this music with new audiences will validate the importance of this study.

A visit to the American Folklife Center of the Library of Congress will result in the discovery of new song literature in the Ritchie/Pickow unpublished collections. This literature will enrich the song repertory for recital, offering elements of regional, historical, and musical interest. Furthermore, these songs will be featured regularly in the historical maritime programs that my husband and I perform for visitors to the Outer Banks of North Carolina.

Finally, I will introduce the songs of Jean Ritchie to a new audience through a culminating recital. Interpreting these songs in innovative ways, I will demonstrate alternative methods for performing folk-songs in recital. Traditional, "classical” performance practices will be applied to singing, while non-traditional, folk-based performance practices will be incorporated in presentation and accompaniment. As a result, the collective understanding of the audience with regard to the songs and history of Appalachia, Eastern North Carolina, and the American Folk-Revival will be elevated, enlightened, and expanded.

It is an honor and a privilege to embark on this research study. It is my sincere hope that at the conclusion of this study and resulting recital, others in the voice community of West Virginia University and beyond will be inspired to choose the songs of Jean Ritchie for formal performance, further sharing the brilliance and innovation of her life's musical work in a way that speaks to a new generation of singers and audiences. 


\section{CHAPTER 2}

\section{Jean Ritchie (1922 - 2015): a brief biography}

From a humble beginning in the Eastern Kentucky mountains to being named the "Mother of Folk," Jean Ritchie lived a modest yet joyous and creative life. The youngest of fourteen children, her family lived on the side of a mountain in a small Kentucky community that descended from immigrants from Ireland and Scotland. Music was a glue that tied the community together, and singing was a part of daily life: a communal experience while working, a reward for work well done, and the centerpiece of times at play. Jean's role as the youngest in her family offered her the unique opportunity to "observe and chronicle the transition from mountain isolation to the modern era of mobility and mass media."

At an early age Jean became intrigued by the hundreds of songs her family sang together, and she was especially interested in their family heritage, completing an extensive family history project when she was in high school. ${ }^{2}$ "Uncle" Jason Ritchie, a cousin of her father, was the family historian and song collector, and he nurtured her interest in her ancestry, helping her to trace it back to ancestor James Ritchie who arrived in America in $1767 .^{3}$ She was familiar with the work of the folk-song collectors who had visited her area, including John Jacob Niles and

\footnotetext{
${ }^{1}$ Clarke, Kenneth, and Mary Clarke. "Kentucky Singers." In The Harvest and the Reapers: Oral Traditions of Kentucky, University Press of Kentucky, 1974: 60 - 79, Accessed January 22, 2019, http://www.jstor.org/stable/i.ctt130hnzs.9.

2Jean Ritchie, Singing Family of the Cumberlands, (Lexington: University of Kentucky Press, 1988 ), 95.

${ }^{3}$ Farmer, H. Russell, and Guy Mendes, Mountain Born: The Jean Ritchie Story, (Lexington, KY: Kentucky Educational Television, 2008), DVD.
} 
John and Alan Lomax, and their interest reinforced her understanding of the value of the traditional music with which she had been raised. ${ }^{4}$

In her autobiography about her early life with her family, Singing Family of the Cumberlands, she acknowledges that at an early age she felt destined for a greater understanding of the world. ${ }^{5}$ She knew that her role would be important in the grand scheme, and that she was a valuable part of the human experience. She was proud of who she was and proud of her "highfalutin"" thoughts and feelings. Even as a little girl she felt a longing to sail across the ocean and share her inner dreams with others. ${ }^{6}$ These musings helped to shape her later interest in social work, in the betterment of humanity, and in the preservation of the musical heritage of the mountain folk.

She began to play the Appalachian lap dulcimer at age seven and used it to accompany herself throughout her life. Her playing techniques were creative and unique, and she was noted for the way she used parallel thirds on the dulcimer to accompany her sung melodies. ${ }^{7}$ She shared her expertise through writing several books on the subject which have served to define traditional Appalachian dulcimer technique.

\footnotetext{
4Jean Ritchie, "Living Is Collecting: Growing Up in a Southern Appalachian 'Folk' Family," In An Appalachian Symposium: Essays Written in Honor of Cratis D. Williams, edited by Williamson J. W., by Brown Louie, 188-98, (Boone, NC: Appalachian State University, 1977): 191, Accessed January 22, 2019, http://www.jstor.org/stable/j.ctt1xp3mkm.19.

${ }^{5}$ Ritchie, Singing Family of the Cumberlands, 71.

'ढlbid., 28.

${ }^{7}$ Ballads, Blues, and Bluegrass, Directed by Alan Lomax, (Friends of Old-Time Music, 1961), DVD (New York: Association for Cultural Equity, 2012).
} 
Possessing a lovely, light soprano voice, she sang easily in a number of folk styles. Alan Lomax, in his preface to her 1965 book Folk Songs of the Appalachians as sung by Jean Ritchie describes her voice in this way: "Jean's quiet, serene, objective voice, the truth of her pitch, the perfection and restraint of her decorations (the shakes and quavers that fall upon the melody to

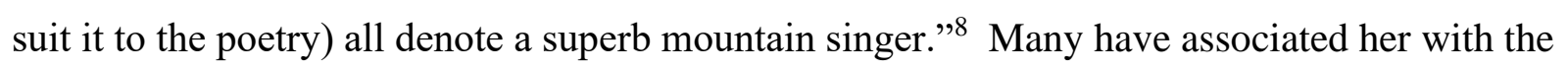
Old Regular Baptist singing style, a form of monophonic hymnody which was sung line by line without accompaniment, using only the "Sacred Harp," the human voice. ${ }^{9}$ She frequently included this unique style in her performances, not for religious reasons, but because she loved the sound. ${ }^{10}$

Following high school, Ritchie continued her studies at the University of Kentucky, graduating in 1946 and moving to New York City to become a social worker at the Henry Street Settlement. Leading "play-party” games with children of diverse ancestries, she began to develop the understanding and philosophy that all peoples are one, a common theme in her later compositions. While in New York she began to sing in public, first for schools and later for the local contradances. ${ }^{11}$ Although her original intention was to return to Kentucky to pursue a career in social work, the connections that she made in New York directed her toward a career in folk music. She met Oscar Brand, Alan Lomax, Woody Guthrie, Pete Seeger, and others who

\footnotetext{
${ }^{8}$ Alan Lomax, Foreword to Folksongs of the Southern Appalachians, $2^{\text {nd }}$ Edition. (Lexington, KY: University Press of Kentucky, 1997), 6.

${ }^{9}$ Jean Ritchie in Mountain Born: The Jean Ritchie Story.

${ }^{10}$ Mountain Talk, "Stories and Songs of Jean Ritchie," WMMT-FM 88.7, Whitesburg, KY, Radio broadcast, Originally aired June 2015, Accessed January 20, 2019, https://www.wmmt.org/mtn-talk-stories-songs-jeanritchie/.

${ }^{11}$ Contradance (contra dance) is a folk dance that is descended from the English country dance tradition. It is a form of social dancing in which two lines of partners face each other and execute a series of steps which are led by a caller. Contradances are customarily danced to live music.
} 
would welcome her into the vibrant folk-revival scene of the northeast. Alan Lomax told her that he wanted to record, "everything you know,"12 and proceeded to make many recordings of her singing and dulcimer playing, which are now in the American Folklife archives of the Library of Congress. Her first formal concert was at the Little Greenwich Mews Theater in 1948 and was sponsored by the contradance society for which she often performed. After this performance, she began to perform on television and radio with Pete Seeger and Oscar Brand. Oscar Brand described Jean as the "greatest traditional singer in America."13 Her style of singing was the "real deal"14 because she grew up in a home where this was just "music," not "folk music."

Ritchie met photographer George Pickow at a square dance in 1948 and they married in 1950. Her family knew no prejudice against this Jewish young man and viewed him as one of “God's Chosen People."15 Pickow's skill in photography offered a vivid visual enhancement to Ritchie's musical collections, and he added important technological expertise to her field recordings. The Ritchie/Pickow partnership did much to preserve the unique culture of the Eastern Kentucky people, tracing the culture back to Jean's forefathers in Ireland and Scotland. Jean and George applied for and won a Fulbright scholarship in 1952 to study the roots of Appalachian folk music in the British Isles. They spent a great deal of time living among the people, collecting, swapping, and recording songs and photographing the lifestyles that were so

\footnotetext{
${ }^{12}$ Jean Ritchie in Mountain Born: The Jean Ritchie Story.

${ }^{13}$ Oscar Brand in Mountain Born: The Jean Ritchie Story.

${ }^{14}$ Tom Paxton in Mountain Born: The Jean Ritchie Story.

${ }^{15}$ Jean Ritchie in Mountain Born: The Jean Ritchie Story.
} 
similar to her Kentucky upbringing. Through this work they were able to make valuable connections to the music that had traveled to America hundreds of years earlier.

Encouraged by Alan Lomax and poet/song collector Carl Sandburg to publish her songs, Jean Ritchie's Swapping Song Book was published in 1952 followed by A Garland of Mountain Song: Songs from the Repertoire of the Ritchie Family of Viper, Kentucky in 1953. Soon after, Oxford University Press showed interest in her introductions to her songs and encouraged her to write a book about her recollections from her early childhood, including more songs from the family repertoire. The resulting book was Singing Family of the Cumberlands, originally published in 1955, which included illustrations by the now-legendary artist Maurice Sendak. ${ }^{16}$

In the years that followed, Jean Ritchie continued to perform and raise her two sons, Jon and Peter, maintaining her family as an important component of her artistic life. Her first album was produced in 1952. In addition to her concert performances she appeared on many radio and television broadcasts. Through her connections with Lomax, Seeger, and Brand, she became an important figure in the American Folk-Revival, participating in the Newport Folk Festivals and serving on the board of directors. ${ }^{17}$ Because of her broad experiences and her awareness of the entire field of folk music she was a valuable member of the board. At one memorable festival concert, she followed Arlo Guthrie's performance of “Alice's Restaurant" with an a cappella rendition of "Amazing Grace," silencing the audience of $10,000 .{ }^{18}$ In the "barest simplicity," she brought her wisdom to that moment. ${ }^{19}$

\footnotetext{
${ }^{16}$ Jean Ritchie in Mountain Born: The Jean Ritchie Story.

${ }^{17}$ Ibid.

${ }^{18}$ Pete Seeger in Mountain Born: The Jean Ritchie Story.

${ }^{19}$ Arlo Guthrie in Mountain Born: The Jean Ritchie Story.
} 
Other important performances included her collaboration with Doc Watson on the live album Jean Ritchie and Doc Watson at Folk City. This album was recorded by George Pickow and mastered by Peter Bartok, son of Béla Bartok, who engineered many recordings for Folkways records. A pivotal moment for Jean Ritchie's career was when her music reached a wider audience with the 1987 recording of her "My Dear Companion" by EmmyLou Harris, Dolly Parton, and Linda Ronstadt.

During the times of the American Folk-Revival, Ritchie began to compose and perform her own compositions. The times were changing in the Kentucky mountains, and Jean composed songs to describe the devastating effects that mining had on the environment and the people. Woody Guthrie's demonstration that "you could make up songs about what is going on right now," inspired many of the folk-song writers of this era to reflect the times with their music. ${ }^{20}$ Some of her songs were composed under the pseudonym "'Than Hall," an abbreviation of her grandfather Jonathan Hall's name. Jean took on this pseudonym for several reasons: first, to protect her mother from those who might criticize Jean's music [incorrectly] ${ }^{21}$ as "Communist," and second, because she "figured if people thought it was a man, they would respect the songs and sing them - women hadn't come into their own. It worked."22

${ }^{20}$ Pete Seeger in Mountain Born: The Jean Ritchie Story.

21 Jean Ritchie, "The Preservationist," In Something's Rising: Appalachians Fighting Mountaintop Removal, by House Silas, Howard Jason, and Smith Lee, 23-44, (Lexington, University Press of Kentucky, 2009 ): 39. Accessed January 22, 2019, http://www.jstor.org/stable/j.ctt2jcqcz.6.

22 Jean Ritchie in Mountain Born: The Jean Ritchie Story. 
In 1977 she was encouraged by Pickow to "add a few modern conveniences" 23 into her recordings. The result of her first foray into an "electric" sound was the album None but One which won Rolling Stone magazine's Critic's Award for Best Folk Album of the Year. ${ }^{24}$

Jean Ritchie's final album, Mountain Born, was released in 1996 and featured performances by her two sons. Upon this, which was the fiftieth year of her professional musical career, Jean reminisced: “All my singing life I've not fit into any categories. I've been too 'folk' to be considered anything else and too 'musically aware' to be considered the 'folk.' A woman once introduced me by saying I couldn't be a 'real' folk singer because I'd been to college." 25

Jean Ritchie's expertise and scholarship earned her many awards including the Fulbright scholarship, two Honorary Doctors of Letters, the National Endowment for the Arts National Heritage Fellowship, and the Bess Lomax Hawes Award for outstanding contributions as a "keeper of tradition."26 She was inducted into the Long Island Music Hall of Fame in 2008, the same year that George Pickow died.

She continued to travel and perform in concert with her two sons until December of 2009 when she suffered a stroke and was no longer able to travel and perform in public. She died in Berea, Kentucky on June 1, 2015.

\footnotetext{
${ }^{23}$ Jean Ritchie in Mountain Born: The Jean Ritchie Story.

${ }^{24}$ Ibid.

$25 \mathrm{Ibid}$.

${ }^{26}$ Jean Ritchie. "Jean Ritchie: (December 8, 1922-)." In Listen Here: Women Writing in Appalachia, edited by Ballard Sandra L. and Hudson Patricia L., (Lexington: University Press of Kentucky, 2003): 508 - 12, Accessed January 30, 2019, http://www.jstor.org/stable/j.ctt2jcf21.90.
} 


\section{Important events in the life and career of Jean Ritchie}

- 1922 Jean Ritchie was born in Viper, KY

- 1946 graduated from University of Kentucky, moved to New York City

- 1948 first formal concert: Little Greenwich Mews Theatre

- 1950 married George Pickow

- 1952 first solo recording: Jean Ritchie Sings Traditional Songs of Her Kentucky Mountain Family

- 1952 Fulbright award to study folk music in the British Isles

- 1955 first publication of Singing Family of the Cumberlands

- 1977 album None But One wins Rolling Stone Critics' Award

- 1996 recording: Mountain Born

- 2008 inducted into the Long Island Music Hall of Fame

- 2008 George Pickow dies

- June 1, 2015 Jean Ritchie dies in Berea, Kentucky ${ }^{27}$

\section{Discography}

- Traditional Songs of Her Kentucky Mountain Family (1952)

- Appalachian folk songs: Black-eyed Susie, Goin' to Boston, Lovin' Hanna (1953)

- Kentucky Mountains Songs (1954)

- Field Trip (1954)

- Courting Songs (1954)

- Shivaree (1955)

- The Singing Family of the Cumberlands (1955)

- Children's Songs \& Games from the Southern Mountains (1956)

- Songs from Kentucky (1956)

- American Folk Tales and Songs (1956)

- Saturday Night and Sunday Too (1956)

- The Ritchie Family of Kentucky (1958)

- $\quad$ Riddle Me This (1959) (with Oscar Brand)

- Carols for All Seasons (1959)

- British Traditional Ballads, Vol 1 (1961)

- British Traditional Ballads, Vol 2 (1961)

- Ballads (2003; vol 1 and 2 above, issued on a single CD)

- Ballads from Her Appalachian Family Tradition (1961)

- Precious Memories (1962)

${ }^{27}$ Karen L. Carter-Schwendler, “Mountain Born: The Jean Ritchie Story.” KET Education. Accessed January 20, 2019. https://www.ket.org/education/resources/mountain-born-jean-ritchie-story/. 
- The Appalachian Dulcimer: An Instructional Record (1963)

- Jean Ritchie and Doc Watson Live at Folk City (1963)

- Time For Singing (1966)

- Marching Across the Green Grass \& Other American Children's Game Songs (1968)

- Clear Waters Remembered (1974)

- Jean Ritchie At Home (1974)

- None But One (1977)

- Christmas Revels. Wassail! Wassail! (1982)

- O Love Is Teasin' (1985)

- Kentucky Christmas, Old and New (1987)

- The Most Dulcimer (1992)

- Mountain Born (1995)

- High Hills and Mountains (1996)

- Childhood Songs (1997)

- Legends of Old time Music (2002, DVD) $)^{28}$

\section{Books by Jean Ritchie and Date of First Publication}

- Jean Ritchie's Swapping Song Book (1952)

- A Garland of Mountain Song from the Repertoire of the Ritchie Family of Viper, Kentucky (1953)

- Singing Family of the Cumberlands (1955)

- The Dulcimer Book (1963)

- Folk Songs of the Southern Appalachians (1965)

- Appleseeds and Soda Straws: Some love songs and legends (1965)

- The Newport Festival Songbook, Jean Ritchie, ed. (1965)

- From Fair to Fair: Folk Songs of the British Isles (1966)

- Celebration of Life: Her Songs, Her Poems (1971)

- Traditional Mountain Dulcimer (1984)

- Jean Ritchie's Kentucky Mother Goose, with Susan Brumfield (2015)

${ }^{28}$ Wikipedia, "Jean Ritchie," Wikipedia Foundation, Updated January 23, 2019, Accessed January 30, 2019. https://en.wikipedia.org/wiki/Jean Ritchie. 


\section{CHAPTER 3}

\section{The role of American folk-song in formal recital}

Formal voice recitals consist characteristically of a series of sets of songs: sometimes chronologically ordered, sometimes featuring a theme, sometimes showcasing a language or style of singing. American folk-song began to enter the traditional Western European repertory in the mid-twentieth century with the song-settings by composers such as Aaron Copland, Charles Ives, and Harry T. Burleigh. These composers set folk songs based on the Schubertian model of integrating piano accompaniment with the vocal line, serving the poetic text, and creating complexity in the relationship between singer and accompaniment. Still, some musicians chose to refrain from the performance of folk-song in recital up through the end of the twentieth century, believing that the songs did not require sufficient skill and were not sophisticated enough for the concert experience. ${ }^{1}$

Thomas Hampson explains in his foreword to the second edition of American Art Song and American Poetry that "poets and composers in America have always been as preoccupied with the contemplation of their existence as artists as with their own unique artistic effort in America. This self-examination is indicative of the far greater collective experience we call the 'American Experience,"” including "the confusing preoccupation with 'art' vs. 'popular' as concepts." ${ }^{2}$ Before continuing a discussion on the value of performing American folk-song in formal recital, a clarification of definitions is in order. First, a working definition of American "folk" music must be established. Second, it must be made clear who "the folk" are. Third, it is

\footnotetext{
${ }^{1}$ Peter Van der Honert, "American Folk Songs As An Alternative In Programming," The Choral Journal 27, no. 8 (1987): 31, Accessed January 22, 2019, http://www.jstor.org/stable/23547238.

2Thomas Hampson, "Foreword," American Art Song and American Poetry, Ruth C. Friedberg and Robin Fisher, Second edition, (Lanham: Scarecrow Press, 2012), ix.
} 
wise to make a distinction between American "folk" music and American "traditional" music because Jean Ritchie's role in our popular culture is often labeled "traditional."” Finally, we must examine and define "formal song" or "art-song" in order to make connections between folk-song and art-song for formal recital. In so doing, the differences and similarities between "art-song" and "popular" song, as Hampson has mentioned, will be addressed to alleviate confusion.

Norm Cohen in his Oxford Music Online article, "Folk Music in the United States," outlines two different definitions of folk music. The first describes folk music as it is defined in the post-1950 American Folk-Song Revival, media-driven world of today.

"In contemporary casual usage in North America, such as one might encounter in trade or popular publications, in newspaper reviews, on the bins in music stores, or on the spines of compact discs and cassettes, the label "folk music" usually means that most, if not all, of the following attributes are true: it is acoustic music performed by a solo act or a small ensemble, often written by the performer(s), rendered in very simple arrangements, and dealing with social or personal issues to which most lay persons can easily relate."

Cohen's second definition is associated with folklorists. This culturally-driven definition describes the music of the people in a society unaffected by industrialization, masscommunication, and urbanization:

"...folk music, whatever its origin, has evolved at the hands of the unsophisticated community in some unselfconscious manner; that with the possible exception of its creation, it exists in oral, not written, media and that it is characterized by variation (so there is no "correct" version)."

${ }^{3}$ Karen Lea Carter-Schwendler, "Traditional Background, Contemporary Context: The Music and Activities of Jean Ritchie to 1977," (PhD diss., University of Kentucky, 1995), 256.

${ }^{4}$ Norm Cohen, "Folk music in the United States," Grove Music Online, Accessed February 16, 2019, http://www.oxfordmusiconline.com.www.libproxy.wvu.edu/grovemusic/view/10.1093/gmo/9781561592630.001. 0001/omo-9781561592630-e-1002241135.

${ }^{5}$ lbid. 
Both of these definitions are valid and are necessary to keep in mind when discussing the music of Jean Ritchie, for her earlier work is informed by the second definition, and her later work by the first.

Craig Hurst elaborates on these definitions as he states: “...the definition of a folk song...is a song with accessible, straightforward lyrics and simple acoustic instrumental accompaniment delivering a simple and straightforward message." ${ }^{6} \mathrm{He}$ continues, "In regard to authentic folk music of the United States, in attempts to define folk music it is agreed that to flourish, folk music needs to exist in the context of a way of life that fosters community with stable conditions favorable to oral transmission." $\mathrm{He}$ continues to add that the traits of a folk-song are typically "antiquity, anonymity, simplicity, and variability in performance." ${ }^{\circ}$

Who are "the folk," who have composed, sung, and shared the American folksongs that we now enjoy? Anya Peterson Royce, quoted in Karen Carter-Schwendler's definitive dissertation on Jean Ritchie's work defines this group as " ... a reference group invoked by the people who share a common historical style, based on overt features and values, and who, through the process of interaction with others, identify themselves as sharing that style." ${ }^{9}$ Peter van der Honert further states, "These shared attributes [of folk

\footnotetext{
${ }^{6}$ Craig W. Hurst, "Twentieth-Century American Folk Music and the Popularization of Protest: Three Chords and the Truth." In Homer Simpson Goes to Washington: American Politics through Popular Culture, edited by Foy Joseph J., by Schultz Stanley K., (University Press of Kentucky, 2008): 219, Accessed January 22, 2019, http://www.jstor.org/stable/j.ctt2jcm66.17.

${ }^{7}$ Ibid, 220.

${ }^{8}$ Ibid.

${ }^{9}$ Anya Peterson Royce quoted in in Karen Carter-Schwendler, "Traditional Background, Contemporary Context: The Music and Activities of Jean Ritchie to 1977," (PhD diss., University of Kentucky, 1995), 6.
} 
musicians] become elaborated, sanctioned, and stabilized by the group over a period of time, resulting in a cohesive community sharing a common heritage...Folk singers sing from memory, consequently they tend to create variations in the songs; communal recreation is the summation of an infinite number of individual recreative acts. The element common to all folk literature, then, is oral transmission." ${ }^{10}$ Hurst agrees: "A folk song singer would therefore be one who draws upon the folk song repertoire of the past, but also could be a popular singer/songwriter whose original songs are in a folk song style."11

Somewhat more problematic is the definition of "traditional" music. Quoting R.P. Elbourne, Carter-Schendler agrees that traditional music:

"...is the popular musical expression of a traditional social structure. It need not be substantively traditional, but it has a traditional structure, being transmitted through time. The legitimation of traditional music recommends its continued performance on the grounds that it has been performed in the past. Its traditionality, its pastness, is referred to as a model. It is the active transmission of traditional music which is the criterion of its traditionality, not simply its identity through time. Traditional music is behavior. Any kind of music, no matter what its origin or content, can become part of a tradition and be transmitted traditionally."12

It should be noted that in traditional folk cultures, song has "extramusical characteristics, integrated with active phases of life, and therefore occupies an important place in the community."13 The purposes of traditional songs define the communities for which they were used. R. Gerald Alvey states that folk culture "consists of those aspects of our lives

${ }^{10}$ Peter van der Honert, "American Folk Songs As An Alternative In Programming," The Choral Journal 27, no. 8 (1987): 31-33. Accessed January 22, 2019. http://www.jstor.org/stable/23547238.

\footnotetext{
${ }^{11}$ Hurst, 219.

${ }^{12}$ L.P. Elbourne, quoted in Carter-Schwendler, 13.

${ }^{13}$ Van der Honert, 33.
} 
learned from those closest to us - from family, friends, peers, and other intimates in an informal, nonacademic, non-institutionalized, unofficial context...folk culture is local traditional culture at the grass roots level."14 Alvey's use of the term "grass roots" is particularly interesting in light of the current Wikipedia article entitled "American Folk Music." According to this article:

"American traditional music is also called roots music. Roots music is a broad category of music including bluegrass, country music, gospel, old time music, jug bands, Appalachian folk, blues, Cajun and Native American music. The music is considered American either because it is native to the United States or because it developed there, out of foreign origins, to such a degree that it struck musicologists as something distinctly new. It is considered "roots music" because it served as the basis of music later developed in the United States, including rock and roll, contemporary folk music, rhythm and blues, and jazz.

Appalachian music is the traditional music of the region of Appalachia in the Eastern United States. It derives from various European and African influencesincluding English ballads, Irish and Scottish traditional music (especially fiddle music), hymns, and African-American blues. First recorded in the 1920s, Appalachian musicians were a key influence on the early development of Old-time music, country music, and bluegrass, and were an important part of the American folk music revival." 15

These contemporary definitions define traditional American folk music, specifically

Appalachian music, and therefore folk-song, as "roots" music, creating a link between

traditional folk music and the American Folk-Revival, in which Jean Ritchie was a pivotal historical figure.

Folk-song is obviously not the same as formal or "art" song, but can be presented as art-song. According to Van den Honert, "Folk song differs from art, or cultivated song, not because it is artless, but because it is the product of many generations, not just

\footnotetext{
${ }^{14}$ R. Gerald Alvey, quoted in Carter-Schwendler, 7.

${ }^{15}$ The Wikipedia Foundation, "American Folk Music," Wikipedia, Updated January 20, 2019, Accessed February 16, 2019, https://en.wikipedia.org/wiki/American folk_music.
} 
one individual." ${ }^{\prime 16}$ Art-songs are composed through conscious creation, where folk-songs are created more for the purposes of continuing traditions and are not necessarily conscious of aesthetic guidelines. Because of this, melodies and texts can vary from verse to verse and from performer to performer. Van den Honert continues: "The path of formal, cultivated music is from the composer to the page to the performer, while the path of folk music is from performer to performer." ${ }^{\prime 17}$ Since neither folk-song nor art-song are developed in a vacuum, these forms can cross over from folksinger to composer. Composed songs can enter the folk tradition, and folk songs can be set by composers, written down for performance by formally trained singers.

"Art" or "formal" song is characterized through its purpose. Art-song is defined as "A song intended for the concert repertory, as opposed to a traditional or popular song," 18 or "A short vocal piece of serious artistic purpose...[a] secular solo song with an independent keyboard accompaniment." ${ }^{\prime 19}$ William Treat Upton, in his 1930 treatise on American art song, sets the standard for song arrangements and composition:

"It is coming to be more and more recognized that modern song can no longer be regarded as merely text plus music or music plus text; it is rather text multiplied by music, music multiplied by text, text so reacting upon music, music so reacting upon text, that the two elements become indissolubly merged into one another, the one really

\footnotetext{
${ }^{16}$ Van den Honert, 31.

${ }^{17}$ Ibid.

18“Art Song," Grove Music Online, Accessed April 17, 2018, http://www.oxfordmusiconline.com/grovemusic/view/10.1093/gmo/9781561592630.001.0001/omo9781561592630-e-0000001381.

${ }^{19}$ Peter H. Dickinson, H. Wiley Hitchcock, and Keith E. Clifton, "Art song," Grove Music Online, Accessed April 25, 2018, http://www.oxfordmusiconline.com/grovemusic/view/10.1093/gmo/9781561592630.001.0001/omo9781561592630-e-1002240068.
} 
incomplete without the other. In fact, it seems to me that this might well be our test of the modern song." 20

Richard Crawford also comments on the importance of the deliberateness of the art song composer: "He looks upon the piano as not just a support, but as an expressive adjunct to the song he is writing, an agent to be used to enhance the expression of the text...to project an artistic

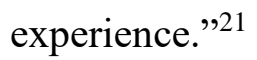

A challenge for composers and singers today is to program folk-song carefully and deliberately for formal recital, presenting folk-songs which permit the accompaniment to serve the poetry of the text, present the emotion of the text accurately, and create a connection between the singer and the audience. In this context, the combination of text, melody, and accompaniment is not only the voice of the composer/arranger, but also of the original singer of the song.

\section{Suggestions from the literature on selecting folk-song for recital}

With the abundance of American folk-song material available to perform, choosing literature for formal recital may be a daunting task. It is important to maintain a high standard of quality when choosing folk-song arrangements. Douglas Moore urged publishers and performers to "use the same criteria for selecting the American songs in their recitals as for the other songs. American songs need not be of lesser quality. To write a good song, it is important to choose

\footnotetext{
${ }^{20}$ William Treat Upton, Art-Song in America: A Study in the Development of American Music, (Boston: Oliver Ditson Company, 1930), 271.

${ }^{21}$ Richard Crawford, "Some Reflections on American Song," American Music Teacher 21, no. 2 (1971): 22, Accessed April 16, 2018, http://www.jstor.org/stable/43534095.
} 
good poetry for the text. Nor should American songs be relegated to filling the role of virtuosic display pieces with little overall musical value."22

When choosing song for recital, suitability for the singer must be taken into consideration early in the process. Technical requirements including range, maturity, and preparedness must first be considered. Our integrity as teachers demands that we choose music for students that is developmentally appropriate. Additionally, as teachers we have the unique opportunity to bring various cultures and histories to new generations of singers and listeners. We are tasked with sharing material from old and new sources to make connections from the musically unknown to the musically familiar. We must present music to our students that stretches their ears, their minds, and their curiosity for learning.

After these decisions have been made, the literature may be chosen and grouped based on its musical, historical, or cultural merit. Recitals including folk-song can be programmed using similar or contrasting ideas or themes, or they can include settings by the same composer or arranger. Texts or textual themes may be compared or contrasted. Songs which display interesting meter changes, modes, texts, or melodic or rhythmic variants are especially appealing for recital. Arranger David W. Snyder states that he always tries to choose melodies with which he has a personal connection, that "...it is important to find something to love about the given tune and to deeply understand the song's structure and history...helping creative ideas come more easily." 23 Many scholars have written on the analysis and musical theories exemplified in the ballads and songs that made up the early Appalachian repertory such as that of the Ritchie

\footnotetext{
22 Jerry L. McBride, Douglas Moore: A Bio-Bibliography. MLA Index and Bibliography Series, 36, (Middleton, Wisconsin: A-R Editions, 2011): 36, E-book, Accessed January 22, 2019, https://ebookcentral.proquest.com/lib/wvu/detail.action?doclD=3115104\#goto toc.

${ }^{23}$ David W. Snyder, "Arranging Fundamentals: Reinventing Melodies," School Band and Orchestra, August, $2009,48$.
} 
family in the Kentucky mountains, ${ }^{24}$ and similar or contrasting analyses may be selected for programming.

Cultural or historical contexts and a desire to make the genre known may also be used for choosing folk-songs for recital. Jean Ritchie traced the roots of traditional songs back to the British Isles ${ }^{25}$ and contrasted them against each other in a compilation recording, ${ }^{26}$ an idea which, in my opinion, could result in a fascinating recital. Others, such as singer and scholar Dr. Phyllis Lewis-Hale, an expert in the Afro-Creole tradition, have chosen folk-song for recital based on the beauty of singing these songs, chosen for their "attractive melodies and exotic rhythms evocative of the habanera and other related dances, elements that make the songs appealing and rewarding to broad audiences and to singers eager to expand their repertoire beyond the familiar Afro-American spiritual song tradition." ${ }^{27}$ Characteristics which contribute to the unique qualities of this genre include syncopation and a melodic adherence to the chordal structure. Additionally, repetition, simple melodic structures, and varied strophic melodies are common to these folk songs, offering a distinctive quality. ${ }^{28}$

\footnotetext{
${ }^{24}$ Eugene Armour, "The Melodic and Rhythmic Characteristics of the Music of the Traditional Ballad Variants Found in the Southern Appalachians," (PhD diss., New York University, 1961); George Foss, "A Methodology for the Description and Classification of Anglo-American Traditional Tunes." Journal of the Folklore Institute 4, no. 1 (1967): 102-26. doi:10.2307/3813914. Accessed February 16, 2019.

${ }^{25}$ Jean Ritchie, From Fair to Fair: Folk Songs of the British Isles. (N.Y.: Walck, 1966).

${ }^{26} J$ ean Ritchie, Field Trip, Greenhays, 2001, CD.

${ }^{27}$ Phyllis Lewis-Hale, "From Old Creole Days: Sampling the Afro-Creole Folk-Song of Louisiana in the Late Nineteenth through the mid-Twentieth Century," Journal of Singing, 73, no. 5 (2017): 481, Accessed January 31, 2019, https://www.nats.org/cgi/page.cgi/ article.html/Journal of Singing/From Old Creole Days Sampling the AfroCreole Folk Song of Louisiana in the Late Nineteenth through the Mid-Twentieth Centuries.

28 Lewis-Hale, 483.
} 
Dr. Jessica Foy Long, in her presentation to the National Association of Teachers of Singing national conference in the summer of 2018 agrees that one of the primary arrangers of Afro-Creole folk-song, Maud Cuney-Hare (1847 - 1936), arranged songs for recital "out of her desire to spread the music of African-Americans. ${ }^{29}$ Camille Lucie Nickerson $(1888$ - 1982), another arranger of Afro-Creole folk-song and an important contributor to Creole scholarship, toured widely as the Louisiana Lady, featuring her arrangements of Creole music in order to advance understanding of the genre. ${ }^{30}$

Dr. Juanita Ulloa, American singer and originator of the "Operachi" style of singing, discusses the characteristics of the Mexican ranchera folk-song style in her 2016 dissertation. A historical survey of the life and work of Mexican nationalist composer Antonio Gomenzanda, this scholarly work describes his use of the ranchera style in his song compositions in the early and middle-twentieth century. A top student of Manuel Maria Ponce, he championed the compositional folk-song style of the ranchera, a "Mexican indigenous folk song tradition that is also played and danced." 31 The rancheras "exemplified Mexican nationalistic musical expressions, exhibiting folk topics, local poets, melodic syncopation, and Mexican rhythmic genres." ${ }^{32}$ As Ulloa explains, these nationalistic songs also borrowed from the Italian bel canto

\footnotetext{
29 Jessica Foy Long, “Forgotten Voices: An examination of Black Louisiana Creole Folk song Through the Works of Maud Cuney-Hare and Camille Nickerson," Paper presented at the National Association of Teachers of Singing national conference, Las Vegas, June 2018, Accessed March 2, 2019, https://www.nats.org/ Library/Las Vegas 2018 presentations handouts/NATS-Forgotten Voices Handout JLong.pdf.

${ }^{30}$ Ibid.

${ }^{31}$ Juanita Ulloa, "The Songs of Mexican Nationalist, Antonio Gomezanda," Order No. 10113640 University of Northern Colorado, 2016, Ann Arbor: ProQuest. Web. Accessed February 16, 2019, 13.

${ }^{32}$ Ibid., 21.
} 
and Italianate operatic style with sustained top notes in the melodic line. ${ }^{33}$ The melodies were combined with indigenous rhythm patterns, heightening their musical interest. ${ }^{34}$ These collaborative pieces integrated singing, playing instruments, and dancing in a three-dimensional

performance. ${ }^{35}$ Gomenzanda chose from the folk-songs of the ranchera to exemplify the spirit of the people of Mexico, specifically those of the Jalisco region. Ulloa chooses to share the folksongs settings of her heritage with a new American audience, expanding the repertoire as well as a cultural understanding of Mexican-American immigrants.

\section{Characteristics of Quality in Folk-Song Arrangements}

Nina Gilbert, in her comprehensive essay on choral arrangements, "How to Evaluate a Folk-song Arrangement," offers a checklist of criteria for evaluating quality in a folk-song arrangement:

Respect for Original

- Is the piece really a folk song?

- Is the arrangement true to the style and character of the original?

- Will the setting teach the singers how the original song goes?

Accessibility

- Is the arrangement itself presented accurately?

- If there are non-standard effects in the music, are they notated consistently and intelligibly?

- If there is a pronunciation guide, is it clear, consistent, and accurate?

- Is the work part of a series?

Music and Words

- How important is the music, compared to the words?

\footnotetext{
${ }^{33}$ Ulloa, 30.

${ }^{34}$ Ibid., 23.

35Ibid, 27.
} 
- How effective is the language of the text?

- Does the original song have musical value that makes it a good choice for a choral setting?

- If the arrangement includes vocal harmonization, do the harmony parts have integrity?

- How does the arrangement end? ${ }^{36}$

A practical application of these principles can be seen through examining the work of the following respected composers noted for arranging folk-songs as art-songs.

Percy Grainger, one of the most prolific and revered folk-song arrangers of the twentiethcentury, embodied these values in his arrangements of British folk-song. With regard to the style of the original song, he committed to "preserve the original folk-song melody" 37 and "employed dynamics and written instructions in the score to ensure the melody's prominence." 38 When composing choral arrangements, he "was meticulous in ensuring that it [the melody] was not buried in the choral texture" 39 and often scored for soloist and choir. Harmonically, he was committed to use dissonance to serve the "underlying emotion of the composition." 40 He was “intent on capturing the peculiar dialect of the performers, their embellishments, and subtle difference in delivery from stanza to stanza."41

\footnotetext{
${ }^{36}$ Nina Gilbert, "How to Evaluate a Folk-Song Arrangement," The Choral Journal 38, no. 4 (1997): 33-36, Accessed January 22, 2019, http://www.jstor.org/stable/23551612.

${ }^{37}$ Wells, 52.

${ }^{38}$ Ibid.

${ }^{39}$ Ibid., 50.

40Ibid., 53.

${ }^{41}$ Ibid., 48.
} 
Harry T. Burleigh is a superb example of an American composer who strove to properly capture the essence of African-American folk-song in his arrangements and compositions. Jean E. Snyder, in her biography of Burleigh's life and work, Harry Burleigh: From the Spiritual to the Harlem Renaissance, sums up his commitment to preserving the original intention of these folk-songs while creating an artistic accompaniment that serves and uplifts the text. "Burleigh presented the spiritual melody simply, but through the emphasis of characteristic rhythmic motifs, expressive use of chromaticism, countermelodies, and colorful, active harmonic progressions and the creation of formal climax and final cadence formulae, [he] transformed it into a classic American art song." ${ }^{22}$ Quoting Olly Wilson, she notes that Burleigh developed a style that was especially significant through the following techniques. Burleigh

- composes a piano line which supports the soloist and "encourages the vocalist to take opportunities to add subtle timbral nuances and rhythmic variations in the performance of the song, a practice idiomatic with traditional performances."

- often employs a traditional call-and-response form in the accompaniment, "filling in the gaps at the ends of phrases with appropriate countermelodies...These accompaniment countermelodies and interjections often contain idiomatic extended syncopated rhythmic patterns characteristic of the religious style." 43

- makes harmonic choices that are "guided by the use of chords that appropriately support the modal implications of the original spirituals," using chromaticism for color and a slow harmonic rhythm that moves toward "dominant-tonic and subdominant-tonic polarities" and timbral choices that define the piano as an accompanying voice. ${ }^{44}$

\footnotetext{
${ }^{42}$ Jean E. Snyder, Harry T. Burleigh: From the Spiritual to the Harlem Renaissance. Music in American Life. (Urbana: University of Illinois Press. 2016), 332.

${ }^{43}$ Ibid., 333.

${ }^{44}$ Ibid., 332-333.
} 
Through these techniques, Burleigh's “art-song spiritual seeks to communicate to an audience the artistic statement of its composer-arranger as interpreted by its performer. It is an object of intrinsic perceptual interest." 45

Burleigh frequently used dialect in his solo song arrangements but was uniquely concerned with the presentation of the song. He composed for singers of any race to perform his arrangements but was aware the singer "might approach the song with too technical a concern for voice quality and miss the spirit of the songs, or a singer somewhat familiar with African American performance but not native to it might fall into unintentional parody in the attempt to imitate that style." 46 He overcame many of these problems by including a statement on the inside cover of his post-1918 G. Ricordi arrangements. This statement outlined correct performance practices for the songs, specifying "a dignified approach that would highlight their message of hope for freedom and human brotherhood." ${ }^{47}$ When he and collaborator Dorothy Bolton published the Old Songs Hymnal in 1929, they possibly employed correct spellings to "grant the hymnal broader use, or, more likely, to keep amateur musicians from parodying African-American dialect while singing these songs." 48

Ruth Crawford-Seeger, in her unique role as $20^{\text {th }}$ century avant-garde composer-turnedfolk-song-transcriber - and stepmother of the great folk-singer Pete Seeger - understood the divide as well as the connection between folk-song and art-song. She states, "Toward fine-art ("classical" or composed) music, it is inevitable that we feel a certain weight of responsibility.

\footnotetext{
${ }^{45}$ Snyder, 333.

${ }^{46}$ Ibid., 320

${ }^{47}$ Ibid.

${ }^{48}$ Brian Moon, "Harry Burleigh as Ethnomusicologist? Transcription, Arranging, and 'The Old Songs Hymnal'," Black Music Research Journal 24, no. 2 (2004): 293, Accessed January 23, 2019, doi:10.2307/4145495.
} 
Folk music, on the other hand, carries few constraining traditions of performance. Emphasis is on straightforwardness rather than variety in manner of performance."49 With regard to Crawford-Seeger's approach in folk-song transcribing and arranging, scholar Ellie Hisama states, “Crawford[-Seeger]'s modernist ear informs her striking choices of harmony, melody, and form in many of her arrangements, and her devotion to the smallest detail in her transcription work can be linked to her precise compositional methods." Crawford-Seeger was not concerned with the inclusion of "unusual intervals" in her arrangements for children, asserting that children could hear and repeat intervals which would seem "strange" or "difficult" to more experienced musicians. ${ }^{50}$

When considering the best practices for arranging folk-songs, Rogie Clark suggests that especial care should be taken: "One should only employ modulations, progressions and harmonic combinations as springs to the character of the song. Do not caricature the melody by using unsuited harmonization... Our modern system of writing music is still incapable of expressing many of the nuances and tonality - often less than half-tones." ${ }^{\text {51 }}$ Composer/arranger David W. Snyder suggests a practical approach. He asserts that an arranger would be wise to begin by "listening to a recording of the original version of the song, or at least a version done in the traditional manner...Assuming there exists plenty of freedom to alter various aspects of the song (melody, harmony, style, meter, et cetera), the most crucial choice the arranger first makes is

\footnotetext{
${ }^{49}$ Ruth Crawford Seeger, "Keep the Song Going," in "The Music of American Folk Song", and Selected Other Writings on American Folk Music, Ruth Crawford Seeger, Larry Polansky, and Judith Tick, Eastman Studies in Music, [17]. (Rochester, NY: University of Rochester Press, 2001), 141.

${ }^{50}$ Ruth Crawford Seeger, American Folk Songs for Children, Musical Score, (Garden City, NY: Doubleday and Company, Inc. 1948), 26.

${ }^{51}$ Rogie Clark, "How should we sing a folk song." NATS Bulletin. 23, no. 1 (1966): 30.
} 
with respect to the overall "feel" of the composition." 52 The goal for the arranger is to "convince the listener that your new arrangement of the tune could, in fact, be the originally intended version. ${ }^{53}$

\section{Choosing Instrumentation}

By definition ${ }^{54}$ the piano is the accompaniment instrument of choice for formal art-song recital. However, not all composers have seen it as such for accompanying folk-song in recital. Percy Grainger "reserved unaccompanied vocal writing for reflective songs that were full of pathos...[and] instrumental textures to accompany folk songs originally sung to dancing." $\mathrm{He}$ "preserves the unaltered tune while writing rhythmically inventive instrumental parts to weave around it. Common devices such as off-beat figures, running scalar passages, and a layering of parts, starting sparsely and building to the end" were employed. ${ }^{55}$ Grainger used "the full breadth of instruments at his disposal even so-called 'popular instruments,' including the guitar, mandolin, ukulele, and 'hammerwood' (xylophone). For the guitars, ukuleles and mandolins, he often notated unique tuning that resulted in parts well within the reach of amateur players." 56 Rogie Clark goes as far as to opine that the use of the piano is unfavorable. "The mandolin, banjo, and especially the guitar, have long been recognized as folk instruments in America. We

\footnotetext{
${ }^{52}$ David W. Snyder, "Arranging Fundamentals: Reinventing Melodies," School Band and Orchestra, August, $2009,48$.

${ }^{53}$ Ibid., 49.

54Jean Snyder, 244.

${ }^{55}$ Wells, 52.

${ }^{56}$ Ibid., 54.
} 
still have not accepted the piano to accompany folk songs, for it lends a certain sophistication and artsi-craftiness which can become the bane of a folk music program."

Ruth Crawford-Seeger allows additionally for the a cappella performance of folk-song as she instructs teachers of small children that "[the teacher] can feel free, as folk singers do, to sing without an instrument (tho if she plays a guitar, ukulele, banjo, auto-harp - or a piano - she should certainly make use of it)." 58

\section{Performance Practices for Performing American Folk-Song in Recital}

A variety of opinions on the performance of folk-song in formal recital can be found in pedagogical, ethnomusicological, and historical literature. One of the most colorful comes from Percy Grainger, who preferred the folk singers he recorded in the field to the classically trained voice:

"These folk singers were kings and queens of song! No concert singer I have ever heard approached these rural warblers in variety of tone - quality, range of dynamics, rhythmic resourcefulness and individuality of style. For while concert singers (dull dogs that they are - with their monotonous mooings and bellowing between $m f$ and $f f$ and with never a $p p$ to their name!) can show nothing better (and often nothing as good) as the slavish obedience to the tyrannical behests of composers, our folk singers were lords in their own domain - were at once performers and creators, for they bent all songs to suit their personal and artistic taste and personal vocal resources." 59

Singer, voice pedagogue, and scholar Rogie Clark creates a bridge from the original folk singer to a classical singer by stating:

\footnotetext{
${ }^{57}$ Rogie Clark, 31.

${ }^{58}$ Ruth Crawford Seeger, "Keep the Song Going," in The Music of American Folk Song, 141.

${ }^{59}$ Lewis Foreman, ed. The Percy Grainger Companion. (London: Thames Publishing, 1981). 57.
} 
"A folk singer is usually left a legacy of song which enables him to carry on a tradition faithfully...entirely from an oral tradition. A folk artist acquires his musical knowledge from an oral tradition, but contributes also to the tradition by creating. He does not copy indiscriminately, but rather remodels his material with such artistry that it leaves his own distinctive mark upon it. The interpreter of folk song not only acquires his material from an oral expression, but also takes advantage of scholarly research. Usually, he has a thorough background in folklore and makes a conscious effort to create the original atmosphere and, with discriminate taste, tries to avoid any artsi-craftiness that might violate the mood of his music." 60

He continues that "a folk singer is merely a storyteller, and that his function is to interpret a song - not imitate." However, the singer is also in part a composer, charged with re-creating a song that he or she has not originally created. "The mode of creation, however, has no bearing on the validity of the finished product. License only is given the singer to permit him enough latitude to avoid direct imitation or stereotype. The singer should keep in mind that traditional authority has already been set."61 Clark's specific instructions for interpreting a folk-song include avoiding a large tone and an intense treatment, employing "a full, clear, round tone"62 When singing folk-songs, "Do not mar their beauty and deep feeling by adopting some fake folk style. Merely sing them like other good songs, as sincerely, as simply and beautifully as possible. It is unnecessary for a singer to employ an artificial folk quality if he studies thoroughly the meaning of the text and music of a song." 63 He adds, "A pleasant voice with a wide range is an asset capable of varied color." 64

\footnotetext{
${ }^{60}$ Rogie Clark, 30.

${ }^{61}$ Ibid.

${ }^{62}$ Ibid.

${ }^{63}$ Ibid., 31.

${ }^{64}$ Ibid.
} 
Clark's opinions on the performance practices of American folk-song include a careful examination of the interpretation itself: "American folk-songs ask...much in the matter of color and nuance from the voice. Sometimes the words are unimportant; and it becomes the pitch of the sound, the breathless tension of the delivery that gives meaning to the song." ${ }^{\circ 5} \mathrm{He}$ states, "A folk song is virtually dead, until the singer revives it, gives it life, and it is he who will keep its contents eternally fresh." ${ }^{.66} \mathrm{He}$ concludes with this poignant statement, "The repetition of a rhythmic figure, and the melodic line of a folk song becomes more than rhythm and melody of a literary and musical form; there is that moment when they might become the heart-beat of the singer himself." 67

Ruth Crawford Seeger also creates connections between the interpretation of folk-singers and classical singers. When describing recordings of traditional folk singers she notes "...most singers...continue from stanza to stanza with little (and in some cases, with no) break in the flow of the song as a whole." 68 "The traditional (folk) singer keeps his on going without interruption of the pulse at stanza ends... Neither the rhythm nor the mood of the song are broken into artificial pauses, breaks, ritards, or 'expression.' This is straightforward music.”69

\footnotetext{
${ }^{65}$ Rogie Clark, 31.

${ }^{66} \mathrm{lbid}$.

${ }^{67}$ Ibid.

${ }^{68}$ Ruth Crawford Seeger, The Music of American Folk Song, 63.

${ }^{69}$ Ruth Crawford Seeger, "Pre-School Children and the American Folk Song," in The Music of American
} Folk Song, 134. 
She instructs the interpreting singer: "Keep-going-ness is one of the notable characteristics in traditional performance of music like this. Do not hesitate...to keep the music going through many repetitions...Do not fear monotony: it is a valuable quality."

With regard to interpreting the meaning of folk-song, Crawford-Seeger is clear: "The singer does not try to make the song mean more, or less, than it does...the tune makes no compromises, is no slower or faster, no softer nor louder. There is no climax-the song 'just stops." "'71 Scholar Ellie Hisama elaborates on Crawford-Seeger's opinion as she states, "A song should stick to a single dramatic mood throughout, avoiding dramatization as one would hear in "the conventional style of fine-art performance."72 However, Hisama clarifies CrawfordSeeger's opinion on the equality of value comparing folk-song to art-song: "In remarking upon these differences between the performance of 'art song' and folk song, Crawford-Seeger does not privilege one over the other or suggest any sort of hierarchy between the two; she simply establishes the different conventions of the styles of performance, emphasizing the importance of keeping them distinct." 73

It is perhaps most meaningful to conclude a discussion of appropriate performance practices in interpreting folk-song as art-song by drawing from Jean Ritchie herself. In her preface to The Swapping Song Book she clearly states her desire for the songs to have a certain freeness about them when sung. The songs are meant to be translated by the singer. Ritchie's

\footnotetext{
${ }^{70}$ Ruth Crawford Seeger, American Folk Songs for Children, 35.

${ }^{71}$ Ruth Crawford Seeger, The Music of American Folk Song, 32-33.

${ }^{72}$ Ellie M. Hisama, "The Ruth Crawford Seeger Sessions," Daedalus 142, no. 4 (2013): 56., Accessed January
} 23, 2019, http://www.jstor.org/stable/43297998.

${ }^{73}$ Ibid. 
wisdom gives gentle permission to the singer to permit the meaning of the song to be filtered through his or her own perception.

'I wish that, when you sing these songs, you won't feel bound to sing every note as you see it in the book. It is almost impossible to capture a folk tune on a piece of paper, with all the little variations that the individual singer puts into the tune each time he sings it. It is impossible, too, to put every word under that right note, or to write notes for every word. Whenever you find a line that has too many words in it for the given music, you just use your own feeling about it and fit them in as it seems best to you. You will find that all the extra words will fall very naturally into place, and you will be singing the song your way, which is what all true folk singers do.

Feel free with these songs, have fun with them. I don't mean that you should consciously change the tune; rather that your voice should give it your own interpretation. However, don't try to dramatize or "put over" these songs when you sing them. Folk songs are straightforward and simple and they have their greatest charm when they are sung just that way." ${ }^{\text {"4 }}$

${ }^{74}$ Jean Ritchie and George Pickow, The Swapping Song Book, Musical Score, (New York: Oxford University Press, 1952), 5-6. 


\section{CHAPTER 4}

\section{Identifying specific songs of Jean Ritchie for formal recital}

\section{Criteria for choosing folk-songs to arrange as art-song}

Jean Ritchie's discriminating taste in selecting quality musical literature for her folk-song publications and recordings simplifies the process of choosing songs for formal recital. It is important to approximate the manner in which her songs were originally performed in order to be true to their original intentions. Additionally, it is necessary to make sure that the presentation of these songs doesn't imply caricature. Instead, following the guidelines as outlined in the previous chapter, I endeavored to select and present these folk-songs as art-songs, embracing traditional classical singing techniques.

My process for selecting folk songs to present as art-song began with immersion into the music of Jean Ritchie through her publications, recordings, and interviews for television and radio. I was able to acquire all of her publications and a number of her recordings. Internet searches and leads from YouTube led me to acquire copies of many of her on-air interviews. Through reading, listening, and viewing, I became familiar with her body of work, and the commentary that elaborated on that work.

Next, I developed a tool to outline the criteria necessary to identify the qualities in a folksong that would make it an excellent choice for formal recital. I adapted the suggestions from the experts cited in Chapter 3 and listed them on a chart in the order that they seemed most important to me. The resulting tool included the following points for analysis, abbreviated for my use: 
- Is this an arrangement or an original tune?

- What is the level of the singer?

- Is it suitable for the designated audience?

- What is the cultural or historical background of the song?

- What was the original purpose of the song?

- Is it an authentic folk song?

- If it is an arrangement, does it honor the integrity of the original song?

- Are the music and words equally important?

- How are the elements of music represented?

Rhythm: Is there rhythmic interest in the song? Is the rhythm syncopated for textual emphasis? Does the piece change metrically at some point? Does the tempo change?

Melody: Is the melody modal? Does it demonstrate expressive leaps or other melodic interest?

Harmony: What is the key of the original piece? Is the piece found in other locations in a different key? Can the harmony be adapted in an interesting way to communicate the same idea?

Form: Does the piece show a particular interest in its formal design? Does it have a refrain or chorus section?

Tone Color: What possibilities exist for instrumentation? How does Jean Ritchie choose to orchestrate her pieces? How do other arrangers and folk singers orchestrate these selections? Does orchestration lend itself best for piano or traditional instrumentation, or does it best speak through the voice singing a cappella?

- Assessment of musical interest, based on the evaluator's opinion

I also provided space to indicate the provenance or composer of the piece on the spreadsheet and note any alternate names for the melody. The chart provided the flexibility for the requirements to change for different singers and audiences. The final evaluation of each piece could be determined through the evaluator's opinion, not a rubric or rule.

I chose lyrics and melodies to which I was drawn, much in the manner described by arranger David Snyder in the previous chapter. Once these were chosen, I began to critique each 
song, according to the established criteria. Examples of two song assessments may be seen in Appendix B.

After identifying the suitability of each song based on these guidelines, I identified several categories by which the songs could be grouped in recital. As I put the songs in groups, I removed some after studying my comments in the criteria. A sample of my working organizational chart is found in Appendix C.

Some songs were easy to eliminate through listening to the text. For example, many traditional ballads are about gruesome murders of young women. This subject was quite titillating in the past, as these ballads served as interesting stories and admonitions for young women to be cautious about their choice of companions. I only chose one from this literary genre for recital consideration. Several of Jean's collected and composed songs deal with the subject of suicide or hanging. While one of the songs on my original list implies this possibility, I felt that for general audiences these subjects would be best avoided. Very possibly my concern is due to the overwhelming amount of training that we as public school teachers are currently receiving on these sensitive subjects. As always, the consideration of the current cultural climate becomes a concern when programming for any audience. Additionally, I made every attempt to vary the themes of the songs in order to maintain textual interest and flow from subject to subject.

Through using the criteria assimilated from the scholarly literature I was able to identify a set of songs that was best suited for a doctoral recital. I then approached the next challenge: finding appropriate arrangements of the songs. 


\section{Process for presenting folk-song as art-song in recital}

While there are a number of arrangements for voice and piano of Appalachian songs such as those by John Jacob Niles, it is difficult to locate art-song arrangements of Ritchie family songs that aren't as well-known. I was challenged with the task of finding a composer/arranger. West Virginia University alumnus and respected West Virginia composer R.J. Nestor became a part of the team. Armed with the list of songs that had met my criteria, he selected the songs that he believed would make the most interesting arrangements for voice with piano accompaniment.

First, he eliminated the prospect of arranging previously copyrighted material, sticking to traditional tunes and lyrics. Jean Ritchie was careful with her publications of the old songs and added notations if she included additional lyrics to traditional songs. However, she frequently built on traditional tunes and lyrics when composing her own songs. For academic purposes, we agreed that it was best to avoid Jean's original compositions for Mr. Nestor's formal arrangements in order that he could retain ownership for future performances.

Mr. Nestor was especially intrigued with setting songs that few have set before. His initial interest in choosing a song for arrangement lay in the story of the lyric because he would then be able to color the music in any way that he desired. He was interested in finding an angle that was different than what others may choose. For example, his previous arrangement of "Shady Grove" was a fatherly interpretation of the young girl seen through his own eyes as father to his daughter Daisy.

After he selected a lyric to set, he made rhythmic connections through the text. He felt that it was imperative that the text must be as the character would speak it, so he worked with the text to fit the dramatization of the music. The keys that he chose to use in setting the songs were related to each other harmonically as they served the text. Through his compositional process, 
Mr. Nestor brought an individual interpretation to each text, creating a setting that told the story of each song, permitting the accompaniment and the voice to interact. Examples of two of these arrangements may be seen in Appendix E.

It was important to me to perform several of the pieces a cappella, as Jean Ritchie frequently performed them. In so doing, the simplicity of melody and poignancy of text would be emphasized.

The remaining selections, primarily those of the American Folk-Revival, were selected to feature a small ensemble of Appalachian instruments: fiddle, Appalachian mountain dulcimer, hammered dulcimer, and guitar. A djembe was also added to the ensemble for rhythmic interest. These pieces would be arranged by the ensemble for a one-time recital performance, intended to educate the audience in the academic setting. By including traditional instrumentation, these folk-songs would be interpreted as they were originally conceived and would be elevated through classical singing techniques.

The visual concept of the recital was intended to be non-traditional: all performers would be on stage throughout the recital. The piano would take center stage, the ensemble would be located stage right, and there would be a location stage left for the soloist to perform a cappella selections. In this setting, the soloist would move from location to location, depending on the required instrumentation for the arrangement. In so doing, the dramatic nature of each folk-song would be isolated and uplifted.

\section{Recital selections from the Jean Ritchie folk-song collection}

The Ritchie family of Viper, Kentucky was regionally famous for the vast wealth of folksongs which had been passed down through many generations since the Ritchie ancestors first 
arrived in America from Scotland. In A Garland of Mountain Song Jean Ritchie recalls: "I've found out that in my family we have somewhere around 300 songs, handed down from the old folks...I'm talking about just the Ritchie songs that have been picked up by ear and handed on

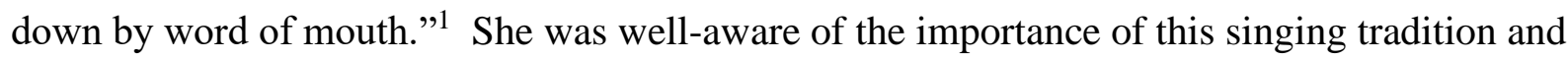
chose to learn everything that she could about these songs, connecting them to her family history. Of particular importance was the memory of "Uncle" Jason Ritchie, who collected songs himself and sang them to Jean, even in his most elderly years. Though his memory for tunes was sometimes inaccurate from verse to verse, and he encouraged Jean to "make up" a tune that would fit the words, she was able to piece together melodies with a certain degree of accuracy.

Of the 300-plus songs of "The Singing Ritchies"2 that Jean was able to catalog, her favorites found their way into her published collections and onto her recordings. The following songs from her published and recorded collections have met the established criteria and are suggested for formal recital.

\section{Songs from the Old World and the New: Appalachian Folk Ballads}

Of the songs that the Ritchie family sang, many were folk ballads that had been passed down from generation to generation. Catalogues online and in print that list the tunes and lyrics of ballads serve as valuable resources for cross-referencing. Of these, I have found the Roud

\footnotetext{
${ }^{1}$ Jean Ritchie, A Garland of Mountain Song: Songs from the Repertoire of the Ritchie Family of Viper, Kentucky. Musical Score, (New York: Broadcast Music, 1953), 14.

${ }^{2} J$ Jean Ritchie, "The song about the Story - the Story behind the Song." In Bloodroot: Reflections on Place by Appalachian Women Writers, edited by Dyer Joyce, 225-32. (University Press of Kentucky, 1998): 226, Accessed January 22, 2019, http://www.jstor.org/stable/j.ctt2jcm47.30.
} 
Folksong Index, an index of English-language lyrics that can be found online in the Vaughn Williams Memorial Library ${ }^{3}$, and Bertrand Bronson's The Singing Tradition of Child's Popular Ballads ${ }^{4}$ to be most helpful. "Child Ballads," named after the song collections of British ethnomusicologist Francis James Child, were known for their dark storytelling, including themes of murder, jealousy, betrayal, cruelty, and chivalry. A significant number of Child ballads were collected by Cecil Sharp and his collaborator Maud Karpeles on a tour through Appalachia between 1916 - 1918. Sharp, a noted ethnomusicologist and song collector, was working to trace the British folk-songs that had found their way into the traditional Appalachian repertory through immigration. Sharp and Karpeles recorded and transcribed these songs and became advocates for the simple lifestyles of the Appalachian people. Songs with these themes served as "soap opera" form of entertainment for the simple folk of the Appalachian mountains in the $18^{\text {th }}$ and $19^{\text {th }}$ centuries.

Any of these ballads could be chosen for formal recital. Most were traditionally performed a cappella and could easily be performed as such. The interesting stories weave tales of woe, destruction, and death, and sometimes of enduring love and faithfulness. Many are based on pentatonic or limited scales. Additionally, some have quite interesting intervallic leaps in the melody, making them particularly appealing.

I chose "Come All Ye Fair and Tender Ladies (The Little Sparrow)," number 451 in the Roud catalog, to open this recital. Jean Ritchie frequently performed this ballad a cappella.

\footnotetext{
${ }^{3}$ Vaughn Williams Memorial Library, Roud Folk Song Index, English Folk Dance and Song Society, Accessed June 11, 2019, https://www.vwml.org/search?q=come\%20all\%20you\%20fair\%20and\%20tender\%20ladies\&collectionfilter=RoudF S;RoudBS\&is=1.

${ }^{4}$ Bertrand Bronson, ed., The Singing Tradition of Child's Popular Ballads, Musical score, (Princeton, NJ: Princeton University Press. 1976).
} 
Though I was able to find an old piano/vocal arrangement of this ballad, I felt that its haunting Dorian melody and interesting leaps would be better served as Jean sang it. True to the topics of the old ballads, this one, an interesting introduction to the textual themes that follow, admonishes young women to mind their morals. From a pedagogical standpoint, the range of an octave makes this an excellent study piece for young singers. The minor $7^{\text {th }}$ leaps upward create an intonation challenge and the necessity for adequate breath energy.

Two Child Ballads, arranged by Mr. Nestor, serve as excellent examples from Jean Ritchie's collection for this recital set: "Lord Bateman (The Turkish Lady)" and "Barbry Ellen (Barbara Allen)." "Lord Bateman (The Turkish Lady)" is a very old song, cataloged as number 53 of the Child Ballads. Jean Ritchie performed it often and nearly always a cappella, as it is suggested here.

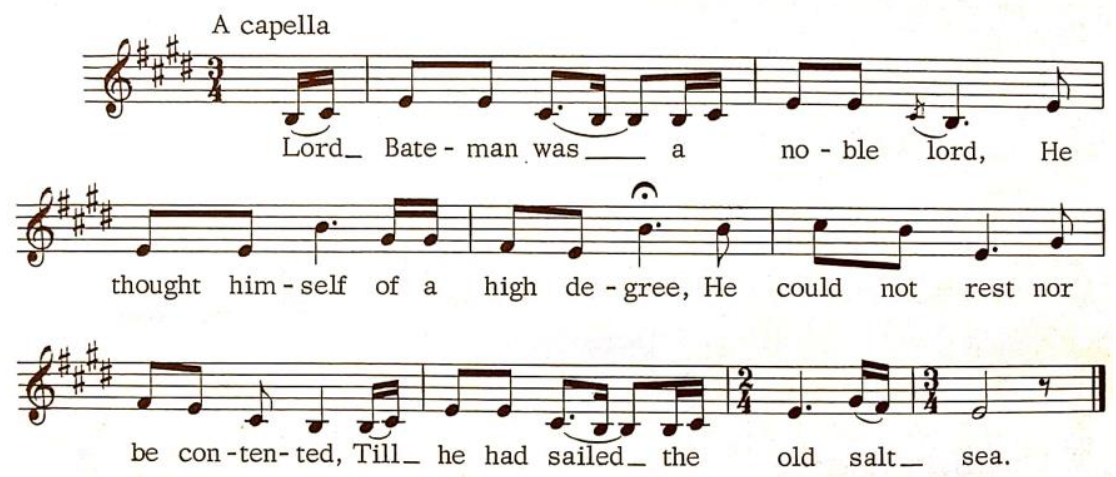

Figure 1. Ritchie, "Lord Bateman"5

The lyrics tell a tale about a gentleman who was imprisoned in Turkey - an exotic locale - and aided by a princess, who in turn sought him in his homeland many years later. The pentatonic melody contains interesting leaps. These upward leaps emphasize the station of the gentleman in

\footnotetext{
${ }^{5}$ Jean Ritchie, Folk Songs of the Southern Appalachians as sung by Jean Ritchie, $2^{\text {nd }}$ Edition. Musical Score, (Lexington, KY: University Press of Kentucky, 1997), 28.
} 
the first verse as they establish his "high degree." To add additional verses, the lyrics must be matched up to the melody, but it is considered appropriate to adjust the rhythm to do so. The change of meter in the last two measures adds rhythmic interest to the turnaround into the next verse. The limited range of just over an octave allows this arrangement to be accessible to the young singer. However, the straightforward storytelling, contrasted with exotic flourishes in the accompaniment, offers an interpretive challenge to a developing singer. R. J. Nestor chose this ballad to set for piano and voice because it is so seldom heard in this setting.

The well-known ballad of hard-hearted Barbara Allen is a natural fit for this recital. Jean Ritchie told of her methodology when collecting songs in the British Isles which were related to those from her Kentucky upbringing in an interview with Fiona Ritchie. ${ }^{6}$ She would always start by playing her own arrangement of Barbara Allen for her new musical friends. They would in turn recognize the song and then want to sing their renditions for her. In this way Jean created a bridge by which she could compare and contrast other songs from the "old world." R.J. Nestor's twist on his arrangement of this ballad drops the final verses of the traditional, eliminating the verse describing the twisted briar and rose bushes that grew over the star-crossed lovers' graves. Mr. Nestor chose to acknowledge Barbry for her long-suffering in the face of William's obvious philandering. By eliminating the depiction of Barbry's "thorny" hard-heartedness, he elevates her humanity as a woman who was wronged. This arrangement offers a stunning climax when William realizes that Barbry is not going to give him her heart, even to save his life. The drama of this moment requires a maturity in presentation by an advanced singer.

6 The Thistle and Shamrock, "Swannanoa Memories - Part 2," NPR. March 14, 2018, Accessed February 3, 2019, https://www.npr.org/2018/03/14/593145943/the-thistle-shamrock-swannanoa-memories-part-2. 


\section{Songs from the Ritchie Family Porch}

These songs are traditional songs that were a part of the daily singing routine of the Ritchie family as appear in Jean's book Singing Family of the Cumberlands. "Skin and Bones" has been a favorite of mine since I first learned it at age 7 from my third-grade music book. When I had the privilege of meeting Jean in 2009, she shared with me that the song "Skin and Bones" was "right off our front porch," hence the title of this set of songs. R.J. Nestor has taken the creepy "ooh" refrain and has given it a coloratura flair. The humorous interactions between the pianist and the singer make it a charming addition to a recital, but the increasing tension of the story and the building complexity of the coloratura passages require the technical skill of an advanced singer.

"The Cuckoo" appears on several of Jean's recordings. As with all folk songs, the text can vary from arrangement to arrangement. Jean states, "My family has always known this song, it seems. It is fairly similar to the variants found in and around Hindman in Knott County, where my father's folks lived. It is one of the saddest and loveliest songs I know." ${ }^{7}$ The pentatonic melody would be easily accessible to a young or developing singer; however, the interaction between voice and piano in this arrangement demands a more advanced skill level.

Jean describes "Shady Grove" in the video biopic Mountain Born as a favorite song of her father, Balis Ritchie, who originally taught her to play the mountain dulcimer. ${ }^{8}$ R.J. Nestor's lovely arrangement is challenging for the pianist. The straightforward melody and divided eightmeasure phrases can easily be interpreted by a young singer.

\footnotetext{
7Jean Ritchie, Folk Songs of the Southern Appalachians as sung by Jean Ritchie, 20.

${ }^{8}$ Jean Ritchie in Mountain Born: The Jean Ritchie Story.
} 


\section{Songs from an Appalachian Christmas}

"Brightest and Best" plays an important role in the holiday celebrations described by Jean in Singing Family of the Cumberlands. There are a number of different melodies for this

Southern Appalachian holiday hymn, but this one carries a certain appeal as it moves in and out of the Mixolydian mode.

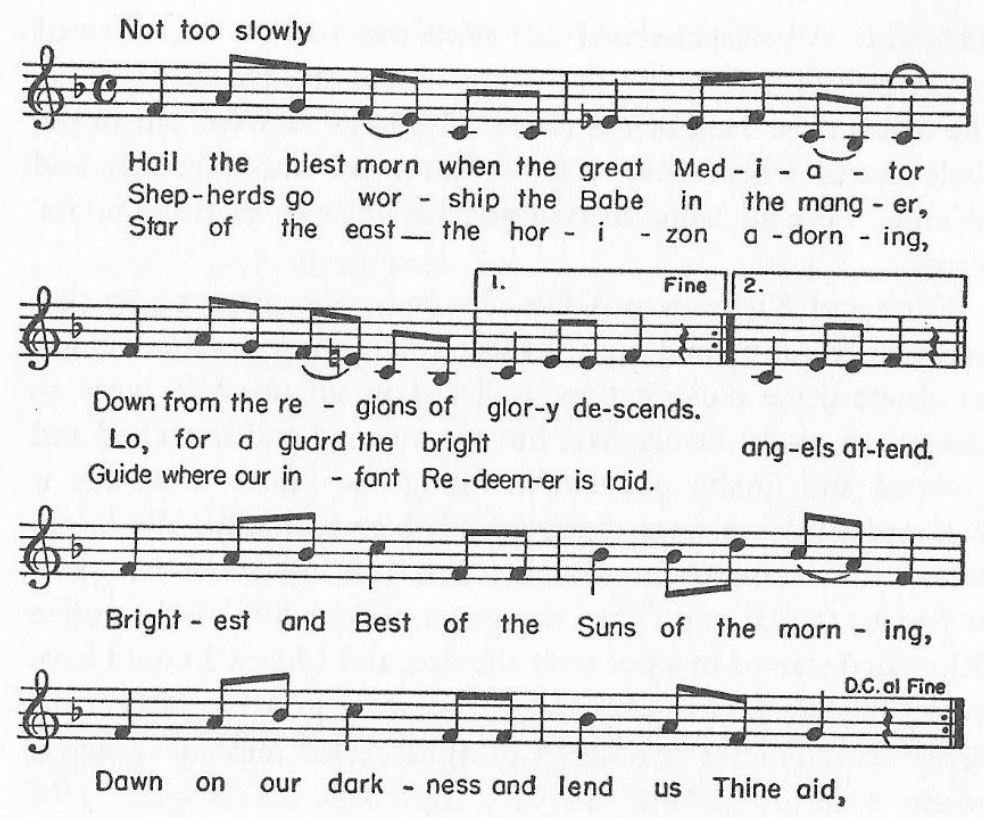

Figure 2. Ritchie, "Brightest and Best"

R.J. Nestor's arrangement combines a festive sleigh bell and "clip-clop" accompaniment, representing the festive season with a majestic second verse to illustrate the kingly nature of the Savior newly-born. The simplicity of breath required for these three strophic verses could make this setting a lovely addition to a holiday program for a young or developing singer.

\footnotetext{
${ }^{9}$ Jean Ritchie, Singing Family of the Cumberlands, 150.
} 


\section{Songs about Love}

Love was a popular topic in the old traditional songs. "Oh Love is Teasin"” initially appears in A Garland of Mountain Song. Jean recalls that she first heard this song sung by an Irish girl named Peggy Staunton with whom she worked at the Henry Street Settlement. According to Jean, "These two or three verses make it one of the prettiest love songs I know. If it's sung in Ireland, it's kin to a whole family of Scots lyric songs, the best known of which is "Waly Waly."10 Incidentally, we in America know "Waly Waly" as "The Water is Wide." This minor pentatonic melody contains octave leaps that create a technical challenge for a developing singer. R.J. Nestor's arrangement also includes time and rhythmic changes within the strophes which require the singer to have an advanced understanding of meter.

\section{Songs of the Carolina Coast}

The Ritchie/Pickow tour of eastern North Carolina in 1951 yielded a number of additions to Jean's folk-song repertory. Two of these songs are included in the suggested recital program: "When the Booze Yacht Run Ashore" and "Nell Cropsey." The 1951 tour and the rationale for the choice of these selections for recital will be discussed at length in Chapter 5 .

\section{Recital selections composed by Jean Ritchie during the American Folk-Revival}

Jean Ritchie's involvement in the American Folk-Revival is a classic example of what happens when a person is in the right place at the right time. To understand her role as a traditional folk-singer in a new era for folk music, one must look at the history of the American folk-song tradition.

\footnotetext{
${ }^{10}$ Ritchie, A Garland of Mountain Song, 14.
} 
Folk-song collector and performer Ralph Rinzler wrote: "The folk movements, which we take for granted today, have their roots in the romance of the pastoral. This idealization of the bucolic can only exist when there is an urban elite or privileged class that is separated from the idealized peasantry by education, social position, and economic resources."11 The Ritchie family, making music in an idyllic setting for two centuries in America, offered the "bucolic" scene against which two important waves of American folk music sprang up in the twentieth century. These revivals politicized folk music, "forging left-wing political ideologies onto populist roots." 12 The first wave developed as a result of the Great Depression, the Works Progress Administration (WPA), and collection efforts of the Library of Congress. To reboot the American economy, President Franklin Roosevelt sent out photographers, musicians, and writers to seek a national identity. ${ }^{13}$ The result of these efforts was "the creation of an archive, if not a canon, of folk music that future generations and movements would draw upon," "marrying politically radical song lyrics to modern compositional techniques." ${ }^{15}$ With the rise of the Communist Party in America, urban intellectuals such as composers Aaron Copland, Henry Cowell, and Charles Seeger, many of whom were not members of the Communist Party, became a part of the newly formed Composers Collective, a "left-wing musician's workshop having the functions of producing and performing new and old revolutionary compositions and formulating

\footnotetext{
${ }^{11}$ Ron Eyerman and Scott Barretta, "From the 30s to the 60s: The folk music revival in the United States," Theory and Society 25, no. 4 (1996): 501, Accessed January 22, 2019, http://www.jstor.org/stable/657909.

${ }^{12}$ Eyerman and Barretta, 501.

${ }^{13}$ Ibid., 508.

${ }^{14}$ Ibid.

${ }^{15}$ Hurst, 223.
} 
specific guidelines for the creation of proletarian music." ${ }^{16}$ A pivotal figure during this time was the young Alan Lomax who had assisted his father, ethnomusicologist John Lomax, in collecting and publishing American Ballads and Folksongs in 1934. Alan Lomax became the director of the archive of American Folk Song at the Library of Congress in 1937 and later became what would be called today an influencer, shaping the way the American people would view folk-song and nurturing the next generation of "urban folksingers." ${ }^{\text {"17 }}$ Lomax worked side by side with composer and academic Charles Seeger whose "thinking, the variety of his work, and his concerns for balance between individual and society made a significant impact on American attitudes toward music and its place in society." 18 Seeger "became the most powerful influence in the development of protest music and the folk music revival that would follow."19 Out of this post-Depression-era cultural stewpot came singers and songwriters such as Woody Guthrie, Pete Seeger, and Burl Ives. Folksingers in this era used traditional music carefully selected to offer specific messages using "songs as weapons." 20 This "first wave" of $20^{\text {th }}$ century folk-song revival fizzled out as the Communist Party USA fell out of favor with the public during the highly publicized anti-Communist activities of Senator Joseph McCarthy and the House Un-American Activities Committee.

The second wave of folk-song revival began in the late 1950s as the now well-known songs of labor struggle evolved into songs about civil rights. ${ }^{21}$ The popularity of television and

\footnotetext{
${ }^{16}$ Eyerman and Barretta, 510.

${ }^{17}$ Ibid., 513.

${ }^{18}$ Hurst, 225.

${ }^{19}$ Ibid.

${ }^{20}$ Eyerman and Barretta, 518.

${ }^{21}$ Hurst, 229.
} 
radio put Pete Seeger, Woody Guthrie, and newcomer Bob Dylan in front of a listening and viewing public. Eyerman states that the rise of this wave was "a complex mix of commercialism and political activism, similar to that in the 1930s and 1940s, combined with a new, and sometimes broader public appreciation of folk music for folk music's sake."22 These new folksingers discovered that they could find their own voices by writing songs that spoke to the times in which they lived. Additionally, an interest in the "purism" of folk music became an important trend. Jean Ritchie found herself in the epicenter of this complex mix of the traditional and the new.

Following her graduation from the University of Kentucky with a degree in social work, Jean moved to New York City to work at the Henry Street Settlement. There she worked with a multi-cultural mix of young girls, teaching them the old songs of her home. ${ }^{23}$ Connections at the Henry Street Settlement opened doors for her to be invited to play mountain dulcimer and sing for "parties, schools, and social clubs." 24

Jean Ritchie became quite involved in the folk culture of New York City in these years and was considered to be "one of the leaders in the folk music revival." 25 She also "singlehandedly popularized the mountain dulcimer." ${ }^{26}$ She was wrongly identified as a "card-carrying

\footnotetext{
${ }^{22}$ Eyerman and Barretta, $520-521$.

${ }^{23} J e a n$ Ritchie, "The Song about the Story - the Story behind the Song," 230.

${ }^{24}$ Ritchie, 231.

${ }^{25}$ House, Silas, and Jason Howard. Something's Rising : Appalachians Fighting Mountaintop Removal. (Lexington, Ky.: University Press of Kentucky, 2009), 30. Accessed July 4, 2019, https://muse-ihuedu.www.libproxy.wvu.edu/chapter/74084.

${ }^{26}$ Ibid.
} 
Communist" in several publications and was horrified by this misinformation. ${ }^{27}$ Jean Ritchie recorded and wrote extensively during the 1960s and had recorded twenty albums by the end of the decade.

An important development in this second wave of revival, now termed the "American Folk-Song Revival," was the conception of the Newport Folk Festival. The earliest two Newport festivals featured musical "stars" but failed to generate popular interest. Eyerman quotes Bruce Jackson: “...the two promoters had missed the point: stars weren't enough to attract big audiences in this phase of the revival. Audiences were beginning to demand significant participation by traditional performers." ${ }^{28}$ In 1961, the Newport Folk Festival reorganized with a new board of directors and a vision for combining "stars" with "tradition and politics." 29 This new board of directors included the college-educated, sophisticated, and folk-music savvy Jean Ritchie.

The re-invented Newport Folk Festivals put Jean in the public eye in a new way. Performing back to back with Pete Seeger, Arlo Guthrie, Joan Baez, and Bob Dylan, her gentle approach to singing, along with the novelty of accompanying herself on the mountain dulcimer, thrust her into a wide arena of influence. She had learned through the music of Woody Guthrie that she could speak into the culture by composing her own material. Now she began recording her own compositions, speaking out against the "mountaintop removal" form of coal mining that was destroying her beloved Appalachian mountains, and pleading for an end to nuclear destruction with "Now is the Cool of the Day." These songs solidified her role as an

\footnotetext{
${ }^{27}$ Ibid., 29.

${ }^{28}$ Eyerman and Barretta, 531.

${ }^{29}$ Ibid., 532.
} 
“environmentalist and an activist." 30 House and Howard quote singer/songwriter Carla Gover who stated in 2009: "Jean is one of the most powerful, subtle, graceful, potent political songwriters ever to come out of this music-laden state, and she does it so effectively that there are many who probably don’t even think of her as a political singer."31

As an epilogue to House and Howard's chapter on Jean Ritchie in their 2009 book

Something's Rising, Jean writes an essay about her sadness at the mining destruction of the Appalachians that were her home. She closes with these thoughts:

"Sometimes, I think of when I was a little girl there, in that place. The mountains circling around us like we were down in a little bowl. My happiest memories are of the times I was walking out in those mountains, on those trails. I had a special rock that jutted out, just big enough for a seat. I'd take me an apple and set there, and I'd talk out loud to the trees and the flowers.

The memories, they just push right down on me sometimes. Everybody who was there isn't there anymore. Nowadays I think mainly about how it looks now and how it used to look. The rest of it is all going to be destroyed now - unless we can stop it."32

\section{Songs from an Appalachian Christmas}

“Wintergrace” appears on Jean's 1987 album Kentucky Christmas: Old and New. This beautiful arrangement of Jean's song for the Winter Solstice features legendary folk ensemble HESPERUS. With its mixed meter, tempo changes, ambiguous modalities, drones, lovely harmonies, and charming text, this piece is a wonderful addition to formal recital with Appalachian ensemble accompaniment. For the singer, the challenge of this song is to

\footnotetext{
${ }^{30}$ House and Howard, 30.

${ }^{31}$ Ibid., 31.

${ }^{32}$ House and Howard, 44.
} 
communicate the feeling of mixed or undefined meter, in the manner that Jean Ritchie performed it, without allowing the beat to become heavy.

\section{Songs about Love}

"Morning Come, Maria Gone" appears in print in Jean Ritchie’s Celebration of Life. This minor pentatonic tune takes its roots from a similar melody and text which Jean documents in Singing Family of the Cumberlands. ${ }^{33}$ The original version was a "kissing game" and the tempo is indicated to be sung "very fast." Jean often took snippets of tunes and lyrics from her traditional upbringing and reworked them to offer a new message. In a much slower tempo, this piece is quite haunting and leaves the listener to wonder what has happened to "Maria." This composition incorporates interesting leaps in the melody in the newly composed B section. This section offers an excellent opportunity to energize the breath and for this purpose would serve a young or developing singer well. In Celebration of Life, Ritchie notes that this piece is best performed with a "drone sound." ${ }^{34}$ A simple arrangement featuring drones in the fiddle and lap dulcimer can be easily worked out by the Appalachian ensemble.

"May Day Day" appears in a YouTube video featuring Jon Pickow. ${ }^{35}$ In the video, Jon explains that his mother composed the song while returning from her Fulbright year in the British Isles. It is intended to reflect a Celtic lilt and features the name "Geordie," Scottish for “George" prominently used as the "darlin's" name. Since Jean wrote it for her husband George,

\footnotetext{
${ }^{33}$ Jean Ritchie, Singing Family of the Cumberlands, 67.

${ }^{34}$ Jean Ritchie, Celebration of Life, Her songs, Her poems, Musical Score, (Port Washington, NY: Geordie

35Jon Pickow, “Jon Pickow - May Day Day (Jean Ritchie)," Filmed [May 2012], YouTube video, 02:54, Posted [May 2012], https://www.youtube.com/watch?v=V-8gekw3kzw.
} Music, 1971), 33. 
Jon sings it using his dad's pet name. This simple, heartfelt song works beautifully with guitar and voice. The limited range of a major $9^{\text {th }}$ and predominantly stepwise melody make this song accessible for performance by a young singer.

\section{Songs about Coal}

"The West Virginia Mine Disaster" is a mining protest song that is best performed $a$ cappella. Unlike many of her mining protest songs, Jean used her own name as the composer of this minor pentatonic tune. In the lyric, a young wife laments the unknown as she has just learned of a flood in the mine where her husband and father of her children has gone to work. There are a number of Jean Ritchie protest songs about mining issues in the Appalachians. This piece, performed as she intended, poignantly demonstrates the sacrifice of human life that has been made to the coal industry. Octave leaps and the gravity of the topic require technical skill, impeccable intonation, and maturity in order for a singer to communicate the story effectively.

The most famous of Jean Ritchie's protest songs, “The L \& N Don't Stop Here Anymore," has been recorded by artists as diverse as Johnny Cash, Michelle Shocked, and Kathy Mattea. Composed in 1965, this song is credited to 'Than Hall, Jean's pseudonym adapted from her grandfather's name. Because of its prominence in her song catalog, this piece is an important addition to formal recital. The simple minor chord structure, octave singing range, and the descriptive text make it easily adaptable by the Appalachian ensemble for performance. This stepwise melody can be comfortably communicated by a young singer who is an excellent storyteller. 


\section{Songs for Humanity}

Jean Ritchie's commitment to the betterment of humanity is seen clearly through her life choices, her family connections, her gentle spirit, and her musical compositions. Her songs speak out against mountaintop removal mining practices, nuclear war, water and air pollution, and racial, gender, and age prejudice. These final recital pieces were selected from a number of her compositions that would equally contribute to a formal voice recital, both in theme and in musical interest.

An outstanding recording of "Let the Sun Shine Down on Me" appears in the commemorative album, Dear Jean, performed by Kim and Reggie Harris. This recording became an inspiration to me as I sought to develop this song for advanced solo voice and djembe. Graduate percussionist Ryan Jobe and I were able to create an exciting arrangement that tells the story simply but adds a soaring gospel-type descant to the final chorus. Credited to 'Than Hall in Celebration of Life, ${ }^{36}$ Ritchie based her composition on an Old Regular Baptist hymn tune, "Father Get Ready."37 The lyrics of the song speak out against nuclear war, referencing the "big cloud a'rising."

In the video biopic Mountain Born, Jean Ritchie speaks of her experiences as a social worker in New York City. While working with youngsters from many cultures, some of whom "wanted to throw chairs at each other," she helped them discover their common humanity through play party games. "None but One," which won the Rolling Stone Critics Award in 1977,

\footnotetext{
${ }^{36}$ Jean Ritchie, Celebration of Life, 43.

${ }^{37}$ Ritchie, Folk Songs of the Southern Appalachians as sung by Jean Ritchie, 50.
} 
was conceived during this time of Jean's life. The song features the $17^{\text {th }}$ century tune "Nonesuch" prominently in the A and B sections.

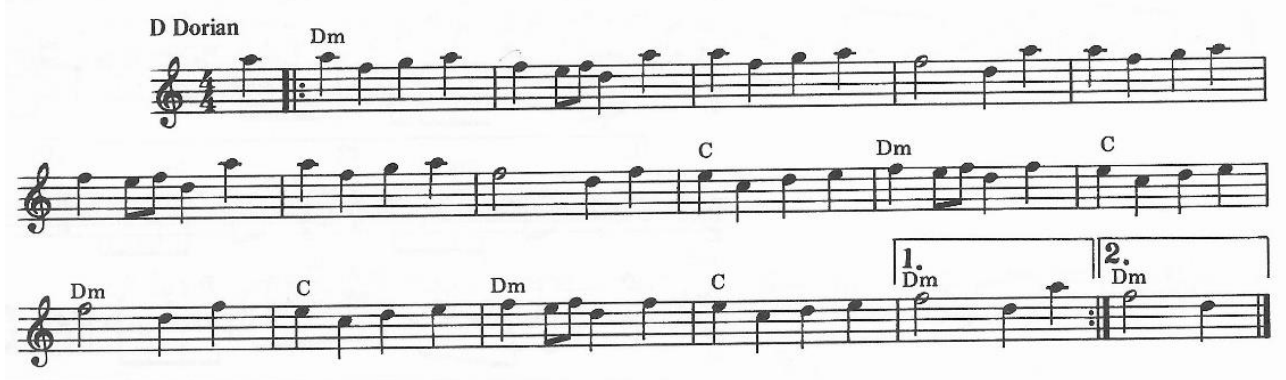

Figure 3. Brody, “Nonesuch”" 38

The sheet music for "None but One" remains unpublished, but the Appalachian ensemble of hammered dulcimer, guitar, and fiddle can recreate an arrangement featuring the Dorian melody with its simple two-chord accompaniment. By layering instruments underneath the voice, the piece builds incrementally to the climactic point, declaring the message that all humans are equally valuable, regardless of race, gender, age, creed, or nationality. This stepwise melody is easy to master by a young singer and would be an excellent piece to use for developing breath energy, since Jean's newly composed C section is set in a tessitura about a $4^{\text {th }}$ higher than the basic "Nonesuch" melody.

I have spent nearly thirty years teaching vocal and instrumental music in the public schools of Western Pennsylvania, working with students of all ages, grade levels, and abilities. I have chosen to conclude this recital with a selection for corporate song, as I would in my

\footnotetext{
${ }^{38}$ David Brody, “Nonesuch,” The Fiddler's Fakebook. Musical Score, (New York: Oak Publications, 1983), 203.
} 
classroom. Jean Ritchie's "Peace Round" reaches out to a divided world to join together, sharing a message of hope. I have taken the liberty of changing the word "dwell" to the more accessible "live" and the phrase "children of all men" to "children of the world," which I believe would be Jean's choice in the current cultural climate.

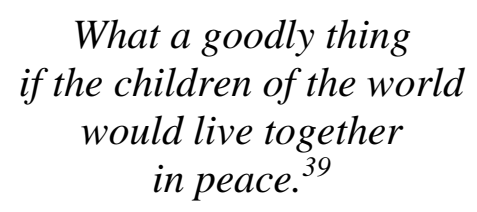

The song is to be presented a cappella and rehearsed first with the entire audience. The audience will then be divided into three sections to sing the round two times through. While there are other songs of Jean's that speak to our common humanity, this song can easily be successfully shared by all, creating a one-time experience that is unique to formal recital.

${ }^{39}$ Ritchie, Celebration of Life, 99. 


\section{CHAPTER 5}

\section{The Ritchie-Pickow 1951 tour of Eastern North Carolina}

In 1951, young newlyweds Jean Ritchie and George Pickow were just beginning to discover the collective power of their interests and experiences. Documents in the American Folklife Center of the Library of Congress show that during this early season of their married life they were already planning to find funding for a collecting tour to Europe. Seeking to find a direction for their collaborative artistic efforts - Jean as a folk-song collector and George as a

photographer - they set out on a short tour of Tennessee, Kentucky, and North Carolina to record local folk musicians and photograph them at work. Their project was a joint one and would serve to demonstrate their commitment to collecting and documenting folklife in the hopes that the result would be funding for a larger tour. Eventually their work paid off and led to their 1952 Fulbright scholarship. This grant enabled them to record and photograph folk musicians throughout the British Isles. The study demonstrated a significant connection from the folk songs of the British Isles to the Kentucky mountain songs of Jean's family.

My interest in this early tour was originally piqued when I realized that Jean and George had collected music on the Outer Banks of North Carolina where I maintain a home. Further investigation led me to discover that the music that they collected was of a local legendary musician, Ivey Scott (1898 - 1958), who resided on Harkers Island, NC, near Cape Fear. In the hopes of discovering folk-songs of the Outer Banks that had never been published, I planned a visit to the American Folklife Center of the Library of Congress to access the Jean Ritchie/George Pickow collection. With the assistance of a Doctoral Research Grant from the College of Creative Arts and the School of Music at West Virginia University, I was able to dig into these early field recordings, now digitized by the AFC staff. 
The complete recordings of Jean's interviews with Ivey Scott, together with recordings of his fiddle-playing and singing, are collected in the archives. The recording quality is quite clear. Jean asks Ivey Scott questions about his music, musing about the similarities and differences between coastal folk-songs and mountain folk-songs, and prompting Scott to share his stories and songs. Jean's interviewing style is comfortable, respectful, and kind, and is refreshing compared to interviews that one might hear today. Her thoughtful questions prompted Mr. Scott to answer carefully and honestly, speaking in his Outer Banks "brogue," commonly heard through the mid-century in the southern Banks. On occasion he would sing a song that sounded similar to one that Jean already knew, and she mentioned that as such on the recordings.

Ivey Scott's style of performance is quite unique. He accompanies himself as he sings by playing the melody in unison with the voice on the fiddle. The collection includes several religious songs, some of which demonstrate his prowess at playing the melody and singing the bass line. In the collection are also fiddle tunes from the square dances that Mr. Scott mentions having accompanied in Ocracoke and Manteo and up and down the Outer Banks. The songs on the recordings include a number of traditional and traditional-sounding ballads. Scott's arrangement of "Barbary Allen" features an altered melody, not an uncommon occurrence in the oral tradition of folk-songs. "The Golden Glove," also known as "The Squire of Tamsworth" and dated to Elizabethan times by Robert Bell, ${ }^{1}$ appears in this collection. The tune is slightly altered from the traditional, but the interesting story about a lady who impersonates a man to ensure that she marries her true love is quite enchanting. Mr. Scott introduces his recording of "The Jolly Cowboy Song" and explains that he first heard it on a recording when he was playing

\footnotetext{
${ }^{1}$ Robert Bell, ed., Ballads and Songs of the Peasantry of England, Taken Down From Oral Recitation and Transcribed From Private Manuscripts, Rare Broadsides and Scarce by James Henry Dixon. (London: The Percy Society, 1846), 70.
} 
for a dance in Manteo. He could not recall the performers on the recording. A little research reveals that the song is also known as "When Work is Done this Fall." The lyrics were originally collected and published by John Lomax, ${ }^{2}$ but the song was a smash hit for Carl T. Sprague in $1925^{3}$ and it is this recording that Ivey Scott may have heard in Manteo.

The Ivey Scott collection of songs contained two that were of regional significance. I have selected these to present in formal recital. One is attributed to Mr. Scott and Ralph Sanders, and Scott indeed states on these recordings that he "made up" the song. The words may be original to them, but the tune is the same as Charles B. Lawlor's popular vaudeville song, "The Sidewalks of New York."4 This ballad, "When the Booze Yacht Run Ashore," is well-known in the southern Outer Banks. It tells the story of an incident during Prohibition in September of 1920 when a ship running liquor between the Caribbean and New York City ran aground on the shoals of the Graveyard of the Atlantic. The bottles of whiskey washed ashore and all of the locals came out to gather up the spoils, resulting in a rollicking, memorable occasion!

\section{When the Booze Yacht Run Ashore}

Down around the bee hive

Harkers Island retreat

Every night and morning,

That's where the fishermen would meet

One day there came a rounder,

A rushing by the door,

He said, boys, let's go to Cape Lookout

There's a booze yacht run ashore!

${ }^{2}$ John Lomax, Cowboy Songs and Other Frontier Ballads, Cowboy Songs and Other Frontier Ballads. (New York: Sturgis and Walton Company, 1911), 53.

${ }^{3}$ Richard L. Matteson, Jr., “Carl T. Sprague," Bluegrass Messengers, Accessed May 18, 2019, http://www.bluegrassmessengers.com/carl-t-sprague-.aspx.

${ }^{4}$ Wikipedia, "The Sidewalks of New York," Wikipedia Foundation, Updated November 16, 2018, Accessed April 23, 2019, https://en.wikipedia.org/wiki/The Sidewalks of New York. 
(chorus)

This way, that way, to the Cape they run

Now the coming of the Adventure

put the fishing on the bum.

Some folks lost their religion

They back-slid by the score,

The king lock stopper still stood ace high

When the booze yacht run ashore.

That's when lots of rounders, for miles

And miles around, kept their gas boats busy

cruising thru Core Sound.

And some of them were happy,

and some of them were sore,

But King Lock Stopper stood ace high,

when the Booze Yacht run ashore.

Things have changed since those times.

Some are up in $G^{\prime}$,

while others they are down and out,

but they all feel just like me,

Some would part with all they got

And some a little bit more

To see another time like that

When the booze yacht run ashore. ${ }^{5}$

The second song of regional significance on this recording tells the gruesome story of the murder of Ella Maude (Nell) Cropsey in Elizabeth City, North Carolina, in 1901. After an evening of entertaining friends in her family home, nineteen-year-old Nell stepped out on the porch to at the request of her gentleman friend, Jim Wilcox. She was reported to have never been seen again, disappearing without a trace. Jim Wilcox told all that he had left her crying on the porch, since they had had a falling out. After Nell's body was found floating in the Pasquotank River over a month after her disappearance, Jim Wilcox was convicted of her murder and sent to the North Carolina State Penitentiary. He maintained his innocence and was

\footnotetext{
${ }^{5}$ David Cecelski, State Library of North Carolina, "David Yeomans: When the Booze Yacht Ran Ashore," NCPedia, Updated March, 2006, Accessed April 23, 2019, https://www.ncpedia.org/listening-to-history/yeomandavid.
} 
pardoned by the governor in 1920. He took his own life in 1934, and the true events of that fateful night were never revealed. The story of Nell's disappearance, murder, and Jim Wilcox's eventual conviction captured the imagination of the American media and consequently the American people in the fall of 1901. During his interview with Jean Ritchie, Ivey informed her that he believed that "Will Cox" wrote this song about himself whenever he was serving time in the state penitentiary. If this was the general belief of the folks who heard and repeated this song, they were quite misinformed! Not only is the name of the accused incorrect in the title of Ivey Scott's version but many of the "facts" in the song don't line up with historical accounts of the event, as reported in the local newspapers at the time. ${ }^{6}$ West Virginia University historian Louis W. Chappell included four different sets of lyrics that chronicled the Nell Cropsey mystery in his 1939 tome, Folk-Songs of Roanoke and the Albemarle, published in Morgantown by Ballad Press. Chappell points out that one of these four different songs is an adaptation of the Irish ballad "The Cruel Miller" ("The Wexford Girl”), Roud 263, ${ }^{7}$ which can in turn be traced to Elizabethan times. ${ }^{8}$ It is this song that Ivey Scott shares on the Harkers Island recording. There are a number of other titles for this tune and lyric, including "The Knoxville Girl," "Hanged I Shall Be," "The Oxford Girl," and "The Prentice Boy." All, in typical "murder ballad" style, tell a story of young lovers walking, an attack with a piece of wood or a knife, and dumping the young girl's body in the river. The author of this set of Nell Cropsey lyrics is unknown, as is the author of traditional "The Wexford Girl."

\footnotetext{
${ }^{6}$ William E. Dunstan, Nell Cropsey and Jim Wilcox: The Chill of Destiny. (Charleston, SC: CreateSpace, 2017).

${ }^{7}$ Louis W. Chappell, Folk-Songs of Roanoke and the Albemarle, (Morgantown, WV: Ballad Press, 1939), 108.

${ }^{8}$ Wikipedia Foundation, “The Knoxville Girl," Wikipedia, Accessed June 11, 2019, https://en.wikipedia.org/wiki/The Knoxville Girl.
} 


\section{Nell Cropsey}

Last Friday night, three years ago,

and cursed be the day,

The devil put it in my heart

To take Nell's life away.

So I started up to her father's house

'Twas eight o'clock that night,

And little did this poor girl think

Against her I had spite.

For I asked her to take a walk

A little way with me,

So we could have a little talk

About our wedding day.

So off we went both side by side,

Till we came to a silent place,

I drew a slab off of the fence

And struck her in the face.

Down on her bended knees she fell

And, oh, for mercy cried:

For heaven's sakes, don't murder me here,

I'm not prepared to die.

But little did I hear her cry

I only struck her more

Until I saw her innocent blood

I never could restore

I wrapped my hands in her coal black hair

And tried to hide my sin;

I drug her down to the riverbank

And there I plunged her in.

I started back up to my mill

and met my servant John;

He said, "What makes your face so pale

And why are you so warm?"

"And what's the cause of so much blood

All on your hands and clothes?"

I told him it was a terrible case

Of bleeding at the nose 
I started back up to my room

And tried to take a rest,

It seemed as if the flames of hell

Was burning in my breast.

Come all who stand around me

Take warning here by me.

Don't ever let the Devil get

The upper hand of you.

If you do, you'll surely be ruined You'll find yourself like me.

A-serving out your 30 long years

In the state penitentiary. ${ }^{9}$

\section{The Wexford Girl}

It was in the town of Waterford

Where I was bred and born

It was in the city of Baltimore

That I owned a flowered farm

I courted many a Wexford girl

With dark and roving eyes

I asked her for to marry me

And yes, was her reply;

I went up to her father's house

About 8 o'clock one night

I asked her for to take a walk

Our wedding day to appoint

We walked along quite easily

Til I came to a level ground

I broke a stake out of the fence

And beat this fair maid down;

Down on her bended knees she fell

And, "mercy she did cry"

Oh, Willie dear, don't murder me here

I'm not prepared to die

He heeded not the words she said

${ }^{9}$ Ivey Scott and Jean Ritchie, Harkers Island Music Legend Ivey Scott, Recorded in 1951, North Carolina Arts Council and the Core Sound Waterfowl Museum and Heritage Center, 2018, CD. 
But he beat her all the more

Til all the ground for yards around

Was in a bloody gore.

I went up to my mother's house

About 12 o'clock that night

My mother, she'd been sittin' up a-waitin'

She took an awful fright

Oh son, dear son, what have you done

What bled your hands and clothes

The answer that I made to my mother

"I was bleeding at the nose;"

I asked her for a candle

To light my way to bed

Likewise, for a handkerchief, to wrap

Around my aching head

I tied it and I twisted it

But no comfort could I find

The flames of hell shown around me

My true love not far behind;

It was in about three weeks before

This fair maid was found

Floatin' down the river

That leads to Wexford town

And all that saw her said

She was fair, a handsome bride

That she was fit for any king

Or any Squire's bride;

I was taken on suspicion

And locked in the Wexford jail

For there was none to pity me

Or none to go my bail

Come ye, all you loyal true lovers

A warning take by me

And never treat your own true love

To any cruelty;

For if you do, you'll rue like me

Until the day you die

You'll hang like me, a murderer

All on the gallows high. ${ }^{10}$

\footnotetext{
${ }^{10}$ Benny Barnes, "The Wexford Girl," Folk \& Traditional Song Lyrics, Accessed June 13, 2019, http://www.traditionalmusic.co.uk/folk-song-lyrics/Wexford Girl.htm.
} 
R.J. Nestor's arrangement of "Nell Cropsey" offers a unique new song-setting for the artsong repertoire. Mr. Nestor has taken an unremarkable melody and set it in such a way that the storytelling becomes both horrifying and fascinating. A simple, loping ostinato in the accompaniment begins the piece as the murderer tells the story, supposedly from prison. He has nothing but time on his hands, and he tells his tale without remorse, embellishing the gory parts with jarring, screeching fioratura passages which suddenly return to the laid-back resolution of his fate. The text is bookended with a lack of responsibility for the murder: the Devil put it in his heart to "take Nell's life away." This arrangement requires skill for the dissonant coloratura passages and maturity for the rather unhinged storytelling, and is best performed by an advanced singer.

The Ritchie/Pickow collection at the American Folklife Center is a fascinating collection of documents and other artifacts. Most interesting to me were the set lists and lyrics that Jean Ritchie would apparently write on whatever paper was handy. These papers included scraps of paper as tiny as an inch square, business envelopes that were split open, the empty backs of newsletters from various organizations, napkins, and bits of brown paper grocery bags. I was thrilled to find in this collection of scrap paper a set list that included "Nell Cropsy [sic]" (Figure 4). A little while later I located Jean's transcription of Ivey Scott's version of the lyrics to "Nell Cropsey." Titled Nell Cropsy [sic] and Will Cox [sic] (Figure 5), these artifacts nearly prove that Jean performed this song after learning it from Ivey Scott. 


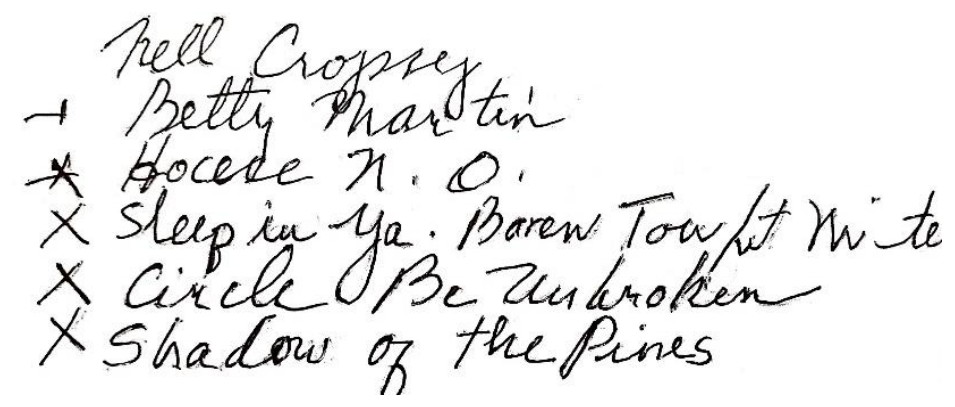

Figure 4. Set list with "Nell Cropsy" at the top from the Ritchie/Pickow collection in the American Folklife Center at the Library of Congress

NSLL. CROPBY AIID WILL, COX

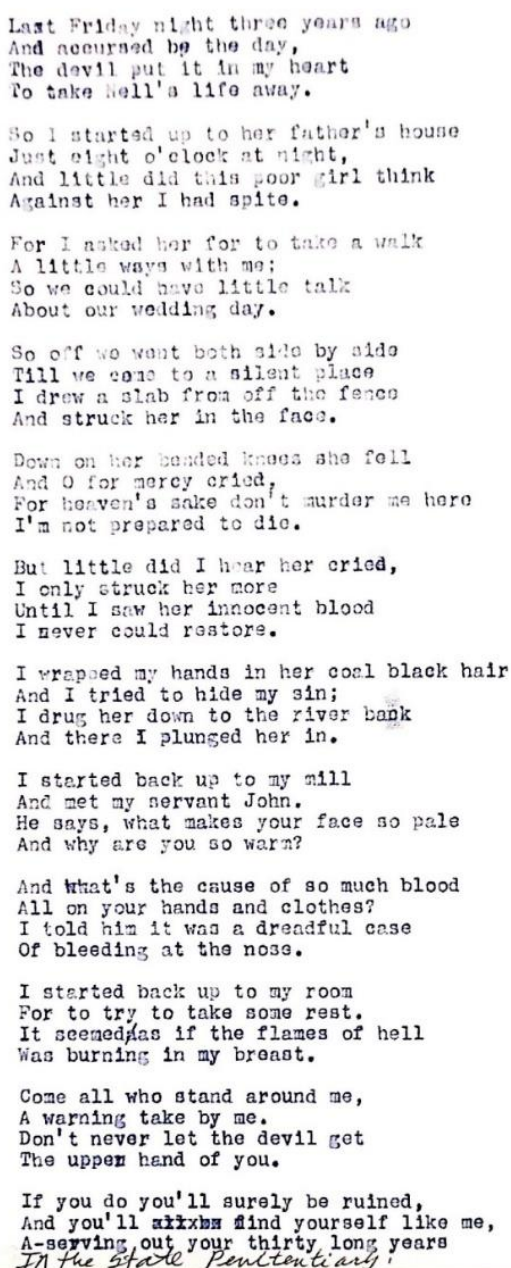

Figure 5: Lyrics to "Nell Cropsy and Will Cox" in the Ritchie/Pickow Collection at the American Folklife Center of the Library of Congress. 
It is important to note that Wayne Martin, director of the North Carolina Arts Council, together with the Core Sound Waterfowl Museum and Heritage Center released a recording of Jean's interviews and Ivey Scott's music in 2016, which I was able to acquire. These recordings, released with the approval of the Ritchie family and the Library of Congress made it possible for me to transcribe the lyrics and the music of this interesting collection for use in recital. The liner notes for the CD make the importance of Jean Ritchie's visit to the Harkers Island community quite clear. Karen Willis Amspacher comments on these recordings of Ivey Scott's music: "Harkers Island will be forever indebted to Jean Ritchie Pickow. Without her, his music would have been lost with the last generation of islanders who knew him." 11

By adding these humble, yet interesting, songs of the tales of coastal Carolina to a formal voice recital, the singer's repertoire is further enriched, offering true stories of historical occurrences to be set and shared by composers and singers alike. These songs now have the potential to reach a new audience, sharing history and traditional music in an innovative setting, educating, diversifying, and expanding the listeners' understanding.

${ }^{11}$ Karen Willis Amspacher, liner notes, Harkers Island Music Legend Ivey Scott. 


\section{CHAPTER 6}

\section{Conclusions}

American folk-song has been a staple in the art-song repertory since the early $20^{\text {th }}$ century. However, a vast wealth of American folk-song - and folk-song that has been borrowed from British Isles roots - is overlooked by singers, teachers, and composers. An investigation into the massive catalog and the life and work of folk-song collector and American Folk-Revival icon Jean Ritchie can open doors to new song literature that enriches and expands the vocal repertory for performance and study. The same musical and textual interest that led collectors and arrangers such as John Jacob Niles and Cecil Sharp to collect and arrange well-known songs such as "Barbara Allen," "I Wonder as I Wander," and "Black is the Color of My True Love's Hair" can be applied to less-known selections. "Lord Bateman," "Come All Ye Fair and Tender Ladies," and even the childrens" "hant" song "Skin and Bones" may be performed in recital, showcasing interesting stories and setting imaginative melodies in new harmonic, formal, and expressive settings. Songs collected and composed by Jean Ritchie offer a wide variety of material that may be arranged for voice recital, utilizing the Schubertian model of dialogue between piano and voice as well as accompaniment by traditional instruments that are more closely associated with the Appalachian region. Regardless of accompaniment or arrangement, the "classically-trained" voice is uniquely gifted and prepared to artistically communicate these songs as effectively in recital as they were presented in their original, humble settings. In using these "new" songs in recital, the repertoire is augmented and diversified, the audience experience is enhanced, and the atmosphere of mutual education and understanding is enriched. 
It is important to remember that selecting folk-songs for recital is a careful and deliberate process. Evaluating folk-songs using the rudimentary elements of music is necessary to determine songs that are most well-suited to the concert setting. As Eugene Armour points out, melodic and rhythmic characteristics of Appalachian folk-songs make them especially interesting to arrange and perform. The mode or scale of the song, its range, the frequency of repeated intervals, the melodic contour, the degree of syncopation as the words are communicated, and the rhythmic figures utilized all play an important role. ${ }^{1}$ In the music preface to Our Singing Country, Ruth Crawford Seeger discusses her initial reticence to evaluate the songs included in the collection for their musical value. She was concerned that she would judge them based on fine art and not folk art. She found herself evaluating them on their "differentness." Did a given song "contain irregularities of meter, rhythm, counterpoint, harmony, intonation, scale, or mode which set it apart as unusual, unique?"2 Such guidelines, established and endorsed by important collectors and respected arrangers of folk-song, serve as principles that can be followed by singers and arrangers alike as folk-songs are chosen to be arranged for the concert stage.

Arrangers of folk-song as art-song are tasked with maintaining the integrity of the original composition and the intention of the song-writer, while communicating new ideas through the accompaniment and setting of the text. Roger D. Abrahams states:

There is a distinction between the creative and presentational techniques of folksong and art song. It is true that a contrast is observable between the two, but the difference is one of degree rather than kind. Both are creations blending individual experience and traditional form. Sophisticated art makes the process of composition into something quite conscious and stresses the innovations brought to form and subject by the individual artist. Folk composition, on the other hand, is oriented more strongly toward the

\footnotetext{
${ }^{1}$ Armour, 31.

${ }^{2}$ Ruth Crawford Seeger, "Music Preface," Our Singing Country, A Second Volume of American Ballads and Folk Songs. John Lomax and Alan Lomax. (New York: The Macmillan Company. 1941), xxix.
} 
continuity of a tradition and is created by those who are much less conscious of the esthetic principles under which the folk performer or creator is working. ${ }^{3}$

The arranger of folk-song as art-song must bridge the gap through an understanding of the tradition and a commitment to authenticity of purpose while creating refinement and style through originality and creative inspiration.

The interpreter of folk-song as art-song must perform with an ear to the integrity of the song as it communicates its original idea. Ruth Crawford Seeger simply states, "The character of a song depends to a great extent on the manner of its singing." ${ }^{4}$ Her admonitions for the proper singing of folk songs include:

- Do not sing “with expression," or make an effort to dramatize.

- Do not hesitate to sing without accompaniment

- When singing without accompaniment, do not make noticeable pauses between stanzas

- When accompaniment is desired, a guitar or banjo is to be preferred. The harmonica, fiddle, dulcimer, auto-harp, and accordion are also appropriate.

- When singing with accompaniment, the voice should rest occasionally between stanzas to allow for instrumental interludes.

and in my opinion, most important:

- Do not "sing down" to the songs. Theirs are old traditions, dignified by hundreds of thousands of singers over long periods of time. ${ }^{5}$

There is no question that my interest in including folk-songs collected by Jean Ritchie and George Pickow in coastal Carolina is personal as well as professional. The folklore of the Albemarle and Outer Banks regions have fascinated me since I was a child. It was a thrilling opportunity to travel to the American Folklife Center of the Library of Congress to seek out the

\footnotetext{
${ }^{3}$ Abrahams, Roger D, and George Foss, Anglo-American Folksong Style, (Englewood Cliffs, N.J: PrenticeHall, 1968), 4.

${ }^{4}$ Seeger, in Our Singing Country, A Second Volume of American Ballads and Folk Songs, xxx.

${ }^{5}$ bbid, xxxi - xxxiii.
} 
songs that Ritchie collected from Ivey Scott when visiting Harkers Island in 1951. However, it is with a certain sense of wonderment that I see the larger picture as the cycle of research winds its way back to West Virginia University through English professor and historian Louis W.

Chappell. Chappell, a native of the Albemarle, North Carolina region, ${ }^{6}$ became an English professor and folklorist at West Virginia University in 1921. His collection of regional folk song recordings is housed in the WVU Libraries and is considered to be a significant primary resource for regional folk-song. ${ }^{7}$ His 1939 publication, Folk Songs of the Roanoke and the Albemarle, is a lifetime collection of songs from his home region. Chappell's insight into Ivey Scott's version of "Nell Cropsey" ties Jean Ritchie's 1951 collecting tour right back to Elizabethan-era British Isles, as he points out that the lyrics and the melody are obviously the same as "The Wexford Girl/The Cruel Miller." Cropsey" songs in his 1939 research proves just how very important this story was to the people of the Albemarle and Outer Banks region during this pre-WWII period. How amazing it is to know that now, eighty years later, a noted West Virginia composer has arranged this very same melody and text, based on a coastal Carolina theme, for a West Virginia doctoral candidate and part-time resident of the Outer Banks to perform for new audiences - at West Virginia University and beyond!

The selections that I have made for the culminating formal voice recital were made using the criteria that was gleaned from scholarly literature on the topic. Appendix B offers an

${ }^{6}$ Louis W. Chappell, Folk-Songs of Roanoke and the Albemarle. (Morgantown, W. Va: Ballad Press, 1939). 7.

7 John A. Cuthbert, "Louis Watson Chappell," e-WV: The West Virginia Encyclopedia, 04 October 2012. Accessed June 13, 2019, https://www.wvencyclopedia.org/articles/1058.

${ }^{8}$ Chappell, 108. 
example of the tool that I developed to compare and contrast melodies, harmonic structure, form, and textual and musical interest as I determined which would be best for the purpose of this recital. The tool is intended to be a guideline and could be easily adapted for other composers, collections, or genres. Appendix $\mathrm{C}$ is a working chart that demonstrates the organization of categories, utilized to determine song groupings for the recital program. The recital program, Appendix D, was developed through studying the format used in Jean Ritchie's final publication, Jean Ritchie's Kentucky Mother Goose. In this book, children's songs were divided into sections that demonstrated their purposes. Groupings included those for home, play-party, counting and rhyming, and "straight" singing. ${ }^{9}$ I have arranged the sections in this recital to reflect the most important topics championed by Jean Ritchie through her music. Finally, the structure of the recital - setting the stage for a cappella performance, piano accompaniment, and Appalachian ensemble accompaniment - was conceived through an interest in offering a new format for formal recital - one that would embrace the folk-song genre in an atmosphere of authenticity without sacrificing the artistic value of the classical voice recital.

The cultural and educational value of our folk-song heritage must be shared with new generations of singers and audiences. As teachers, we have a responsibility to keep the memory and history of the past alive for our students. This study seeks to bridge folk-song and art-song, enriching the repertoire for the future. We can communicate to our students that beauty in singing can be spun by a fine thread from the simplicity of a folk-singer's craft to the breath, line, and space of the classically-trained singer. Through comprehending and recreating the

\footnotetext{
9Jean Ritchie with Susan Brumfield. Jean Ritchie's Kentucky Mother Goose, Musical Score, (Milwaukee,
} WI: Hal Leonard Books, 2015), vii-viii. 
sensations that initiate beauty in phonation and articulation, the classical singer can express the simplicity of the folk-singer's intentions as easily as one might interpret a lied or mélodie.

As we seek new resources for song literature, folk-songs with rich histories such as those from the life-work of Jean Ritchie can be sought for new and innovative arrangements. Libraries and new technologies make unpublished and original sources more readily available than ever before. Criteria developed and inspired by revered scholars and built on the fundamental elements of music serve as benchmarks leading to quality in choosing specific folk-songs and arrangements for performance. Formal recitals of folk-song, shared in innovative yet familiar contexts, reach out to new audiences and inspire them to a new understanding and interest in classical singing.

Jean Ritchie has demonstrated the value of preserving the musical past and sharing it with new listeners, opening doors of appreciation between disciplines, cultures, and generations. Through her inspiration we are able to share with fresh insight the beloved stories and songs of our ancestors, enriching our repertoire and offering new joy, depth, and artistic excellence to our singing tradition. 


\section{Bibliography}

Abrahams, Roger D. "Folklore on Records: Jean Ritchie, Folksinger in a Commercial Medium." Midwest Folklore 10, no. 2 (1960): 96-100. Accessed January 22, 2019. http://www.jstor.org/stable/4317854.

Abrahams, Roger D, George Foss, and George Foss, Foss, George. Anglo-American Folksong Style. Englewood Cliffs, N.J: Prentice-Hall, 1968.

The American Folklife Center. The Library of Congress. Accessed February 3, 2016. https://www.loc.gov/folklife/.

Armour, Eugene. "The Melodic and Rhythmic Characteristics of the Music of the Traditional Ballad Variants Found in the Southern Appalachians." PhD diss., New York University, 1961.

"Art song." Grove Music Online. http://www.oxfordmusiconline.com/grovemusic/view/10.1093/gmo/9781561592630.001. 0001/omo-9781561592630-e-0000001381. Accessed April 17, 2018.

Ballard, Sandra L., and Patricia L. Hudson, eds. "Jean Ritchie: (December 8, 1922 -).” In Listen Here: Women Writing in Appalachia. Lexington: University Press of Kentucky, 2003. Accessed April 17, 2016. http://www.jstor.org.proxy-iup.klnpa.org/stable/j.ctt2jcf21.

Bell, Robert, ed. Ballads and Songs of the Peasantry of England, Taken Down From Oral Recitation and Transcribed From Private Manuscripts, Rare Broadsides and Scarce by James Henry Dixon. London: The Percy Society, 1846.

Benny Barnes, “The Wexford Girl,” Folk \& Traditional Song Lyrics, http://www.traditionalmusic.co.uk/folk-song-lyrics/Wexford_Girl.htm, Accessed June $13,2019$.

Birinbeo. "Jean Ritchie - A Tribute to the Pickows at the Abbey Hotel 1991." Filmed [March 2018]. YouTube video, 59:23. Posted [March 2018]. https://www.youtube.com/watch?v=9AwXpojOoro.

Bronson, Bertrand Harris, ed. The Singing Tradition of Child's Popular Ballads. Musical score. Princeton, NJ: Princeton University Press. 1976.

Brauner, Cheryl A. and Lucy M. Long. "Ritchie, Jean." In The New Grove Dictionary of American Music, Vol. 4. Edited by H. Wiley Hitchcock and Stanley Sadie. New York: Grove's Dictionaries of Music, 1986.

Brody, David. The Fiddler's Fakebook. New York: Oak Publications. 1983. Musical Score. 
Carter-Schwendler, Karen L. Mountain Born: The Jean Ritchie Story. KET Education. Accessed January 20, 2019. https://www.ket.org/education/resources/mountain-bornjean-ritchie-storyl.

Carter-Schwendler, Karen Lea. "Traditional Background, Contemporary Context: The Music and Activities of Jean Ritchie to 1977." PhD diss., University of Kentucky, 1995.

Cazden, Norman. "Regional and Occupational Orientations of American Traditional Song." The Journal of American Folklore 72, no. 286 (1959): 310-44. Accessed February 16, 2019. doi:10.2307/538582.

Chappell, Louis W. Folk-Songs of Roanoke and the Albemarle. Morgantown, W. Va: Ballad Press, 1939.

Claghorn, Charles E., ed. Biographical Dictionary of American Music. West Nyack, NY: Parker Publishing Company. 1973. S. v. "Ritchie, Jean.” 376.

Clark, Rogie. "How should we sing a folk song." NATS Bulletin. 23, no. 1 (1966). 30-31, 50.

Clark, Edgar Rogie. Moment Musical; Ten Selected Newspaper Articles. Fort Valley, Ga: Dept. of Music, Fort Valley State College, 1940.

Clarke, Kenneth, and Mary Clarke. "Kentucky Singers." In The Harvest and the Reapers: Oral Traditions of Kentucky, 60-79. University Press of Kentucky, 1974. Accessed January 22, 2019. http://www.jstor.org/stable/j.ctt130hnzs.9.

Cohen, Norm. 2013 "Folk music in the United States." Grove Music Online. 16 Feb. 2019. http://www.oxfordmusiconline.com.www.libproxy.wvu.edu/grovemusic/view/10.1093/g mo/9781561592630.001.0001/omo-9781561592630-e-1002241135.

Crawford, Richard. "Some Reflections on American Song." American Music Teacher 21, no. 2 (1971): 20-23. Accessed April 16, 2018. http://www.jstor.org/stable/43534095.

Crumb, R. "Beautiful Music.” Pinterest. Accessed November 28, 2018. https://www.pinterest.ca/pin/279926933059656929/.

Cuthbert, John A. "Louis Watson Chappell." e-WV: The West Virginia Encyclopedia. 04 October 2012. Web. Accessed June 13, 2019.

DeRienzo, Paul. "Jean Ritchie, 92, the Village's 'Mother of Folk."” The Villager. June 18, 2015. Accessed July 2, 2019. https://www.thevillager.com/2015/06/jean-ritchie-92-the-villagesmother-of-folk/.

DesRosiers, Mary. "Jean Ritchie: An Unbroken Circle." Sing Out! The Folk Song Magazine. 41 (3) Nov. 1996. 56 - 64. Accessed April 17, 2016. http://navigatoriup.passhe.edu/login?url=http://search.proquest.com.proxyiup.klnpa.org/docview/1203475?accountid=11652. 
Dicaire, David. The Early Years of Folk Music: Fifty Founders of the Tradition. Jefferson, NC: McFarland \& Co, 2010.

Dickinson, Peter, H. Wiley Hitchcock, and Keith E. Clifton. "Art song." Grove Music Online. Accessed April 17, 2018. http://www.oxfordmusiconline.com/grovemusic/view/10.1093/gmo/9781561592630.001. 0001/omo-9781561592630-e-1002240068.

Doster, Meredith, Mark Freed, Tom Hansell, Fred J. Hay, Phil Jamison, Rebecca Branson Jones, Steve Kruger, Jordan Laney, Trevor McKenzie, John Cloyd Miller, Natalya Weinstein Miller, Ron Pen, Emily Schaad, Leila Weinstein, and Dave Wood. "Appalachian Music Films: From Appalshop to Zwigoff." Appalachian Journal 42, no. 3/4 (2015): 358-89. Accessed January 22, 2019. http://www.jstor.org/stable/26341093.

Dunstan, William E. Nell Cropsey and Jim Wilcox: The Chill of Destiny. Charleston, SC: CreateSpace, 2017.

Edwards, Gavin. "10 Folk Albums Rolling Stone Loved in the 1970sYou Never Heard." Rolling Stone. July 2, 2015. Accessed March 26, 2016. http://www.rollingstone.com/music/lists/10-folk-albums-rolling-stone-loved-in-the1970s-you-never-heard-20150702/jean-ritchie-none-but-one-20150702.

Ellis, Bill. "Ritchie, Jean (1922 -).” In American Folklore: An Encyclopedia. Ed. by Jan Harold Brunvand. New York: Garland Publishing, 1996.

Eyerman, Ron, and Scott Barretta. "From the 30s to the 60s: The Folk Music Revival in the United States." Theory and Society 25, no. 4 (1996): 501-43. Accessed January 22, 2019. http://www.jstor.org/stable/657909.

Facing South. "Remembering Appalachian Folksinging Legend Jean Ritchie." The Institute for Southern Studies. Accessed February 10, 2016. http://www.southernstudies.org/2015/06/remembering-appalachian-folksinging-legendjean-ri.html.

Farmer, H. Russell, and Guy Mendes. Mountain Born: The Jean Ritchie Story. DVD. Lexington, KY: KET, 2008.

Feintuch, Burt. Kentucky Folkmusic: An Annotated Bibliography. Lexington: The University Press of Kentucky. 1985.

Feintuch, Burt. "Singers, Musicians, and Other Performers." In Kentucky Folkmusic: An Annotated Bibliography, 33-50. University Press of Kentucky, 1985. http://www.jstor.org/stable/j.ctt130jqr3.7. Accessed January 22, 2019.

Filene, Benjamin. "Romancing the Folk: Public Memory and American Vernacular Music in the Twentieth Century." PhD diss., Yale University, 1995.

Friedberg, Ruth C, and Robin Fisher. American Art Song and American Poetry. Second ed. Lanham: Scarecrow Press, 2012. 
Folk Alliance. "Jean Ritchie 1998 Folk Alliance International Lifetime Achievement Award Recipient." Filmed [November 2010]. YouTube video, 11:40. Posted [November 2010]. https://www.youtube.com/watch?v=J1pwPxujreU.

Foreman, Lewis, ed. The Percy Grainger Companion. London: Thames Publishing, 1981.

Foss, George. "A Methodology for the Description and Classification of Anglo-American Traditional Tunes." Journal of the Folklore Institute 4, no. 1 (1967): 102-26. doi:10.2307/3813914. Accessed February 16, 2019.

georgepickow. "jean and edna ritchie sing four marys." Filmed [1966]. YouTube video, 02:33. Posted [September 2007]. https://www.youtube.com/watch?v=mrPTrkpO6EQ.

georgepickow. "Jean Ritchie music in irish kitchen galway." Filmed [March 2007]. YouTube video, 07:22. Posted [March 2007].

georgepickow. "ritchie family reunion 1955." Filmed [Dec. 1955]. YouTube video, 06:24. Posted [November 2007]. https://www.youtube.com/watch?v=x5auCjcZPYo.

Gilbert, Nina. "How to Evaluate a Folk-Song Arrangement." The Choral Journal 38, no. 4 (1997): 33-36. Accessed January 22, 2019. http://www.jstor.org/stable/23551612.

Gold, John R., and George Revill. "Gathering the Voices of the People? Cecil Sharp, Cultural Hybridity, and the Folk Music of Appalachia." GeoJournal 65, no. 1/2 (2006): 55-66. Accessed January 22, 2019. http://www.jstor.org/stable/41148022.

Goldsmith, Peter, and General D. Watson. "Review Essay: Smithsonian/Folkways Reissues." Ethnomusicology 40, no. 1 (1996): 121-31. Accessed January 30, 2019. doi: $10.2307 / 852448$.

Gould, S. Baring, and Cecil J. Sharp, ed. English Folk-songs for Schools. London: J. Curwen and Sons, 1900.

Gregory, E. David. "Lomax in London: Alan Lomax, the BBC and the Folk-Song Revival in England, 1950-1958." Folk Music Journal 8, no. 2 (2002): 136-69. Accessed January 22, 2019. http://www.jstor.org/stable/4522667.

Gregory, E. David, Peter Kennedy, and Shirley Collins. "Alan Lomax. (1915-2002)." Folk Music Journal 8, no. 4 (2004): 548-57. Accessed January 22, 2019. http://www.jstor.org/stable/4522738.

Haughton, Matthew. "POETRY: Dulcimer after Listening to Jean Ritchie." Appalachian Journal 38, no. 2/3 (2011): 295. Accessed January 22, 2019. http://www.jstor.org/stable/41320303.

Hisama, Ellie M. "The Ruth Crawford Seeger Sessions." Daedalus142, no. 4 (2013): 51-63. Accessed January 23, 2019. http://www.jstor.org/stable/43297998. 
House, Silas, and Jason Howard. Something's Rising: Appalachians Fighting Mountaintop Removal. Lexington, Ky.: University Press of Kentucky, 2009. Accessed July 4, 2019. https://muse-jhu-edu.www.libproxy.wvu.edu/chapter/74084.

Hurst, Craig W. "Twentieth-Century American Folk Music and the Popularization of Protest: Three Chords and the Truth." In Homer Simpson Goes to Washington: American Politics through Popular Culture, edited by Foy Joseph J., by Schultz Stanley K., 217-32. University Press of Kentucky, 2008. Accessed January 22, 2019. http://www.jstor.org/stable/j.ctt2jcm66.17.

“Jean Ritchie Discography.” Discogs. Accessed February 3, 2016. http://www.discogs.com/artist/476000-Jean-Ritchie.

Jean Ritchie CD Project Trust. Dear Jean. Nashville: Compass Records. 2014. CD.

Johnson, Graham and Richard Stokes. A French Song Companion. New York: Oxford University Press. 2000.

Jones, Brian. "Finding the Avant-Garde in the Old-Time: John Cohen in the American Folk Revival." American Music 28, no. 4 (2010): 402-35. doi:10.5406/americanmusic.28.4.0402.

Jones, Loyal. "Jean Ritchie, Twenty-Five Years After." Appalachian Journal 8, no. 3 (1981): 224-29. Accessed January 22, 2019. http://www.jstor.org/stable/40932401.

Jon Pickow. "Jon Pickow - May Day Day (Jean Ritchie)." Filmed [May 2012]. YouTube video, 02:54. Posted [May 2012]. https://www.youtube.com/watch?v=V-8gekw3kzw.

Karpeles, Maud. Cecil Sharp: His Life and Work. Chicago: The University of Chicago Press. 1967.

Kimball, Carol. Song: A Guide to Art Song Style and Literature. Milwaukee, WI: Hal Leonard Publications. 2005.

Krassen, Miles. Appalachian Fiddle. New York: Oak Publications, 1973. Musical Score.

Lawless, Ray McKinley. Folksingers and Folksongs in America; a Handbook of Biography, Bibliography, and Discography. New York: Duell, Sloan and Pearce, 1965.

Lewis-Hale, Phyllis. "From Old Creole Days: Sampling the Afro-Creole Folk-Song of Louisiana in the Late Nineteenth through the mid-Twentieth Century." Journal of Singing. 73, no. 5 (2017). 481-495. Accessed January 31, 2019. https://www.nats.org/cgi/page.cgi/_article.html/Journal_of_Singing/From_Old_Creole_D ays_Sampling the Afro-

Creole_Folk_Song_of_Louisiana_in_the_Late_Nineteenth_through the MidTwentieth_Centuries. 
Library of Congress. Jean Ritchie and George Pickow collection, 1923 - 2015. Finding Aid. Washington, D.C.: Library of Congress, 2015. Accessed May 21, 2019. http://hdl.loc.gov/loc.afc/eadafc.af016008.

Lomax, Alan. Ballads, Blues, and Bluegrass. Directed by Alan Lomax. Produced by Friends of Old-Time Music, 1961. New York: Association for Cultural Equity, 2012. DVD.

Lomax, John. Cowboy Songs and Other Frontier Ballads. New York: Sturgis and Walton Company, 1911.

Lomax, John and Alan Lomax. Our Singing Country: A Second Volume of American Ballads and Folk Songs. New York: The Macmillan Company. 1941.

Long, Jessica Foy. "Forgotten Voices: An Examination of Black Louisiana Creole Folk Song Through the Works of Maud Cuney-Hare and Camille Nickerson." Paper presented at the National Association of Teachers of Singing national conference, Las Vegas, June 2018. Accessed March 3, 2019. https://www.nats.org/_Library/Las_Vegas_2018_presentations_handouts/NATSForgotten_Voices_Handout_JLong.pdf.

Matteson, Richard L., Jr. "Carl T. Sprague.” Bluegrass Messengers. Accessed May 18, 2019. http://www.bluegrassmessengers.com/carl-t-sprague-.aspx.

McBride, Jerry L. 2011. Douglas Moore: A Bio-Bibliography. Mla Index and Bibliography Series, 36. Middleton, Wisconsin: A-R Editions. E-book. Accessed January 22, 2019. https://ebookcentral.proquest.com/lib/wvu/detail.action?docID=3115104\#goto_toc.

Mitchell, Gillian. The North American Folk Music Revival: Nation and Identity in the United States and Canada, 1945-1980. Ashgate Popular and Folk Music Series. Aldershot, England: Ashgate. 2007.

Mitchell, Gillian A. M. "Visions of Diversity: Cultural Pluralism and the Nation in the Folk Music Revival Movement of the United States and Canada, 1958-65." Journal of American Studies 40, no. 3 (2006): 593-614. Accessed January 22, 2019. http://www.jstor.org/stable/27557862.

Moon, Brian. "Harry Burleigh as Ethnomusicologist? Transcription, Arranging, and "The Old Songs Hymnal"." Black Music Research Journal 24, no. 2 (2004): 287-307. Accessed January 23, 2019. doi:10.2307/4145495.

Mountain Talk. "Stories and Songs of Jean Ritchie." WMMT-FM 88.7, Whitesburg, KY. Radio broadcast. Originally aired June 2015. Accessed January 20, 2019. https://www.wmmt.org/mtn-talk-stories-songs-jean-ritchie/.

Murphy, Michael. The Appalachian Dulcimer Book. St. Clairsville, OH: Folksay Press, 1976. Musical Score. 
Music Tree Artist Management. "Jean Ritchie Bibliography.” Accessed February 3, 2016. http://www.music-tree.com/ritchiebiblio.html.

Music Tree Artist Management. “Jean Ritchie Discography.” Accessed February 3, 2016. http://www.music-tree.com/ritchiedisco.html.

Miller, Terry E. Folk Music in America: A Reference Guide. New York: Garland, 1986.

Niles, John Jacob. The Ballad Book of John Jacob Niles. New York: Bramhall House, 1960. . Seven Kentucky Mountain Songs. New York: Schirmer, 1928. Score.

Olson, Ted. "Ritchie, Jean: (b. 1922) Folk Singer." In The New Encyclopedia of Southern Culture: Volume 12: Music, edited by Malone, Bill C., by Wilson Charles Reagan, $342-$ 44. University of North Carolina Press, 2008. Accessed January 22, 2019. http://www.jstor.org/stable/10.5149/9781469616667_malone.166.

Parsons, James. The Cambridge Companion to the Lied. Cambridge Companions to Music. Cambridge: Cambridge University Press. 2004.

Pen, Ron. "Musical Instruments from the Collection of John Jacob Niles." In Kentucky by Design: The Decorative Arts and American Culture, edited by Kelly, Andrew, by Doss, Erika, Hirsch, Jerrold, and Burks, Jean M., 203-12. University Press of Kentucky, 2015. January 22, 2019. http://www.jstor.org/stable/j.ctt15hvzmd.54.

Pen, Ron. "Ritchie, Jean." Grove Music Online, Oxford Music Online. Oxford University Press. Accessed April 17, 2016. http://www.oxfordmusiconline.com/subscriber/article/grove/music/A2263055.

Rahkonen, Carl. The Real Song Catchers: American Women Pioneers of Ethnomusicology. A paper presented at the Music Library Association. Women's Music Round Table. Austin, Texas. February 14, 2003.

Rankin, Steve. Singing the Moon Up: The voice of Jean Ritchie. 2005. Accessed January 31, 2019. www.singingthemoonup.com.

Richmond, W. Edson. Midwest Folklore 2, no. 3 (1952): 198-99. Accessed January 22, 2019. http://www.jstor.org/stable/4317346.

Ritchie, Jean. A Garland of Mountain Song: Songs from the Repertoire of the Ritchie Family of Viper, Kentucky. New York: Broadcast Music, 1953. Musical Score.

Ritchie, Jean. Celebration of Life: Her songs, Her poems. Port Washington, NY: Geordie Music, 1971. Musical Score.

Ritchie, Jean. The Dulcimer Book. New York: Oak Publications, 1963. Musical Score.

Ritchie, Jean. Field Trip. Port Washington, NY: Greenhays. 2001. CD. 
Ritchie, Jean. Folk Songs of the Southern Appalachians as sung by Jean Ritchie. $2^{\text {nd }}$ Edition. Lexington, KY: University Press of Kentucky, 1997. Musical Score.

Ritchie, Jean. From Fair to Fair: Folk Songs of the British Isles. N.Y.: Walck, 1966. Musical Score.

Ritchie, Jean. High Hills and Mountains. Chicago: Greenhays. 1979. CD.

Ritchie, Jean. Jean Ritchie's Dulcimer People. New York: Oak Publications, 1975. Musical Score.

Ritchie, Jean. "The L\&N Don't Stop Here Anymore" In Sing Out! the Folk Song Magazine, 44, 108-109. Accessed March 16, 2016. http://navigatoriup.passhe.edu/login?url=http://search.proquest.com.proxyiup.klnpa.org/docview/1203651?accountid=11652.

Ritchie, Jean. "Living Is Collecting: Growing Up in a Southern Appalachian "Folk" Family." In An Appalachian Symposium: Essays Written in Honor of Cratis D. Williams, edited by Williamson J. W., by Brown Louie, 188-98. Boone, NC: Appalachian State University, 1977. Accessed January 22, 2019. http://www.jstor.org/stable/j.ctt1xp3mkm.19.

Ritchie, Jean, ed. The Newport Folk Festival Songbook. New York: Alfred Music, 1965. Song anthology.

Ritchie, Jean. None but One. Chicago: Greenhays. 1981. 33 1/3 rpm.

Ritchie, Jean. "The Preservationist." In Something's Rising: Appalachians Fighting Mountaintop Removal, by House Silas, Howard Jason, and Smith Lee, 23-44. University Press of Kentucky, 2009. Accessed July 4, 2019. http://www.jstor.org/stable/j.ctt2jcqcz.6.

Ritchie, Jean. "The Song about the Story-The Story behind the Song." In Bloodroot: Reflections on Place by Appalachian Women Writers, edited by Dyer Joyce, 225-32. University Press of Kentucky, 1998. Accessed January 22, 2019. http://www.jstor.org/stable/j.ctt2jcm47.30.

Ritchie, Jean. Singing Family of the Cumberlands. Lexington: University of Kentucky Press, 1988.

Ritchie, Jean. "Jean Ritchie: (December 8, 1922-)." In Listen Here: Women Writing in Appalachia, edited by Ballard Sandra L. and Hudson Patricia L., 508-12. University Press of Kentucky, 2003. Accessed January 30, 2019. http://www.jstor.org/stable/j.ctt2jcf21.90.

Ritchie, Jean and Doc Watson. Jean Ritchie and Doc Watson at Folk City. New York: Folkways Records, 1963. 33 1/3 rpm.

Ritchie, Jean and George Pickow, The Swapping Song Book. New York: Oxford University Press, 1952. Musical Score. 
Ritchie, Jean, Jonathan Pickow, Peter Pickow, Larry Packer, David Düsing, and Pamela Warrick-Smith. Mountain Born: Jean Ritchie \& Sons Sing Cabin Country. Port Washington, N.Y.: Greenhays Recordings, 1999. CD.

Ritchie, Jean with Susan Brumfield. Jean Ritchie's Kentucky Mother Goose. Milwaukee, WI: Hal Leonard Books, 2015. Musical Score.

Rogers, Sally with Jean Ritchie. "Sowing Seeds of Love for Traditional Music: An interview with Jean Ritchie." Pass it On: The Journal of the Childrens Music Network. Accessed January 30, 2019. https://childrensmusic.org/pio-article.aspx?ID=42.

Scott, Ivey and Jean Ritchie. Harkers Island Music Legend Ivey Scott. Recorded in 1951. North Carolina Arts Council and the Core Sound Waterfowl Museum and Heritage Center, 2018. CD.

Seeger, Ruth Crawford. American Folk Songs for Children. Garden City, NY: Doubleday and Company, Inc. 1948. Musical Score.

Seeger, Ruth Crawford. American Folk Songs for Christmas. Garden City, NY: Double Day and Company, Inc. 1953. Musical Score.

Seeger, Ruth Crawford, Larry Polansky, and Judith Tick. "The Music of American Folk Song" and Selected Other Writings on American Folk Music. Eastman Studies in Music, [17]. Rochester, NY: University of Rochester Press, 2001.

Segal, Marcia. "Gems from the Jean Ritchie and George Pickow collection." Folklife Today: American Folklife Collection and Veterans History Project. Library of Congress. July 3, 2017. Accessed May 21, 2019. https://blogs.loc.gov/folklife/2017/07/gems-from-thejean-ritchie-george-pickow-collection/.

Sepko, Delaina. "The Archive of American Folk Song, The Library of Congress recording laboratory and notions of American identity." Fontes Artis Musicae 62, no. 2 (2015): 92 100. Accessed January 22, 2019. http://www.jstor.org/stable/24579447.

Sharp, Cecil J. American-English Folksongs from the Southern Appalachian Mountains. New York: G. Schirmer, 1918.

Sharp, Cecil J. English Folksongs from the Southern Appalachians. London: Oxford University Press, 1960.

Simpson, Bland. The Mystery of Beautiful Nell Cropsey. Chapel Hill, NC: The University of North Carolina Press, 1993.

Snyder, David W. "Arranging Fundamentals: Reinventing Melodies." School Band and Orchestra. August, 2009. 48 - 51.

Snyder, Jean E. Harry T. Burleigh: From the Spiritual to the Harlem Renaissance. Music in American Life. Urbana: University of Illinois Press. 2016. 
Southern Gothic the Podcast. "Episode 008: Beautiful Nell's Tragic Tale.” Published June 5, 2018. Accessed May 18, 2019. https://www.youtube.com/watch?v=-VvrtdCO1jY.

Stone, Ruth M. Let the Inside Be Sweet: The Interpretation of Music Event among the Kpelle of Liberia. Bloomington, IN: Trickster Press, 2010.

“"Than Hall Discography." Discogs. Accessed February 10, 2016. http://www.discogs.com/artist/978779-Than-Hall.

The Thistle and Shamrock. "Swannanoa Memories - Part 2." NPR. March 14, 2018. Accessed February 3, 2019. https://www.npr.org/2018/03/14/593145943/the-thistle-shamrockswannanoa-memories-part-2.

Ulloa, Juanita M. "The Songs of Mexican Nationalist, Antonio Gomezanda." Order No. 10113640 University of Northern Colorado, 2016. Ann Arbor: ProQuest. Web. 16 Feb. 2019.

Upton, William Treat. Art-Song in America: A Study in the Development of American Music. Boston: Oliver Ditson Company, 1930.

Van Den Honert, Peter. "American Folk Songs As An Alternative In Programming." The Choral Journal 27, no. 8 (1987): 31-33. Accessed January 22, 2019. http://www.jstor.org/stable/23547238.

Vaughn Williams Memorial Library. Roud Folk Song Index. English Folk Dance and Song Society. Accessed June 11, 2019. https://www.vwml.org/search?q=come\%20all\%20you\%20fair\%20and\%20tender\%20ladies\&coll ectionfilter $=$ RoudFS; RoudBS\&is $=1$.

Weissman, Dick. Which Side Are You On?: An Inside History of the Folk Music Revival in America. New York: Continuum, 2005.

Wells, Brent. "Percy Grainger, champion of the folk song: the collecting and composition of Grainger's choral folk-song settings." The Choral Journal 51, no. 9 (2011): 46-55. http://www.jstor.org/stable/23561746.

Wenner, Hilda E., and Elizabeth Freilicher. Here's to the Women: 100 Songs for and about American Women. New York: The Feminist Press, 1987. Song anthology.

Wikipedia. "American Folk Music.” The Wikipedia Foundation. Updated January 20, 2019. Accessed February 16, 2019. https://en.wikipedia.org/wiki/American_folk_music.

Wikipedia. "The Cherry-Tree Carol.” The Wikipedia Foundation. Updated January 30, 2019. Accessed March 17, 2019. https://en.wikipedia.org/wiki/The_Cherry-Tree_Carol.

Wikipedia. "Contra dance." The Wikipedia Foundation. Updated October 7, 2019. Accessed October 23, 2019. https://en.wikipedia.org/wiki/Contra_dance. 
Wikipedia. "The Sidewalks of New York." The Wikipedia Foundation. Updated November 16, 2018. Accessed April 23, 2019. https://en.wikipedia.org/wiki/The_Sidewalks_of_New_York.

Wikipedia. "Jean Ritchie.” Wikipedia Foundation. Updated January 23, 2019. Accessed January 30, 2019. https://en.wikipedia.org/wiki/Jean_Ritchie.

Wilentz, Sean, and Greil Marcus, ed. The Rose and the Briar: Death, Love and Liberty in the American Ballad. New York: W.W. Norton, 2005.

Winick, Stephen. “Jean Ritchie (1922 -2015).” Folk Music Journal, January 2016. 117-119, Music Index, EBSCOhost. Accessed April 16, 2016. http://eds.b.ebscohost.com.proxyiup.klnpa.org/ehost/pdfviewer/pdfviewer?vid=4\&sid=90a8eb82-0e04-45e3-a549dcb5092e1533\%40sessionmgr107\&hid=117.

Work, John W. "Changing Patterns in Negro Folk Songs." The Journal of American Folklore 62, no. 244 (1949): 136-44. Accessed January 22, 2019. doi:10.2307/536308.

Wyatt, Lucius R. "The Present State and Future Needs of Research in Black Concert and Recital Music." Black Music Research Journal 1 (1980): 80-94. Accessed January 22, 2019. doi:10.2307/779296.

WYMT Television. “Jean Ritchie: Interview on 'Mountain Life' (1994).” Filmed [1994]. YouTube video, 01:47. Posted [June 2014]. https://www.youtube.com/watch?v=mUPiW80sL1s.

Young, Chester Raymond. "The Observance of Old Christmas in Southern Appalachia." In An Appalachian Symposium: Essays Written in Honor of Cratis D. Williams, edited by Williamson J. W., by Brown Louie, 147-58. Boone, NC: Appalachian State University, 1977. Accessed January 22, 2019. http://www.jstor.org/stable/j.ctt1xp3mkm.16. 


\section{APPENDIX A}

\section{Jean Ritchie: Collected and Composed Songs and Arrangements Suitable for Formal Voice Recital, An Annotated Bibliography}

Julianne Laird, 2016

The American Folklife Center. The Library of Congress. Accessed February 3, 2016. https://www.loc.gov/folklife/.

An excellent beginning for research on the topic of Jean Ritchie, the American Folklife Center website provides links to many resources, including archived collections, field recordings, lectures and the informative blog, Folklife Today.

Ballard, Sandra L., and Patricia L. Hudson, eds. "Jean Ritchie: (December 8, 1922 -).” In Listen Here: Women Writing in Appalachia. Lexington: University Press of Kentucky, 2003. Accessed April 17, 2016. http://www.jstor.org.proxy-iup.klnpa.org/stable/j.ctt2jcf21.

The four pages of this article serve as another description of the incredible impact Jean Ritchie had on the preservation of folk traditions in Appalachia. Following the introduction, the authors have compiled primary and secondary sources of more information on Jean's work. The remaining pages of this article on Jean Ritchie are from the early pages of Singing Family of the Cumberlands.

Brauner, Cheryl A. and Lucy M. Long. "Ritchie, Jean." In The New Grove Dictionary of American Music, Vol. 4. Edited by H. Wiley Hitchcock and Stanley Sadie. New York: Grove's Dictionaries of Music, 1986.

This article was written in part by Lucy Long, ethnomusicologist of Bowling Green State University. The article is primarily a biographical sketch; however especially helpful to this particular topic is a mention of collected folk songs ("The Cuckoo, she's a pretty bird) and original songs of Ritchie, including, "Let the sun shine down on me."

Claghorn, Charles E., ed. Biographical Dictionary of American Music. West Nyack, NY: Parker Publishing Company. 1973. S. v. "Ritchie, Jean.” 376.

This brief description of Ritchie's life and work contains a listing of several of her folk song arrangements, including "A Tree in the Valley-O," "What'll I do with the Baby-O," and several of her albums of songs and dulcimer tunes. 
DesRosiers, Mary. "Jean Ritchie: An Unbroken Circle.” Sing Out! The Folk Song Magazine. 41

(3) Nov. 1996. 56-64. Accessed April 17, 2016. http://navigator-

iup.passhe.edu/login?url=http://search.proquest.com.proxy-

iup.klnpa.org/docview/1203475?accountid=11652.

This journal article contains photographs of Ritchie performing and playing singing games with children and transcriptions of several of her collected folk song arrangements. Biographical quotes, anecdotes, and Jean's recollections are included as well as an excellent discography and bibliography of her work.

Dicaire, David. The Early Years of Folk Music: Fifty Founders of the Tradition. Jefferson, NC: McFarland \& Co, 2010.

This book serves as an excellent overview of folk music and musicians throughout American history. Jean Ritchie's role in the folk tradition is described as a "bridge artist" between American folk music of the 1920s and 1930s and the popularity of the styles of the 1960s.

Edwards, Gavin. "10 Folk Albums Rolling Stone Loved in the 1970sYou Never Heard." Rolling Stone. July 2, 2015. Accessed March 26, 2016. http://www.rollingstone.com/music/lists/10-folk-albums-rolling-stone-loved-in-the1970s-you-never-heard-20150702/jean-ritchie-none-but-one-20150702.

Gavin Edwards gives a synopsis of Ritchie's life and work and then cites the original Rolling Stone review from 1977. The original review is rather vague, but it is important to note that Ritchie's work was indeed reviewed for Rolling Stone, a benchmark of critical acclaim.

Ellis, Bill. "Ritchie, Jean (1922 -).” In American Folklore: An Encyclopedia. Ed. by Jan Harold Brunvand. New York: Garland Publishing, 1996.

An excellent review of Ritchie's life and work (although published before her death in 2009), this source contains a reference to the first time she was recorded by Artus Moser at the Renfro Valley Folk Festival in Kentucky in 1946.

Facing South. "Remembering Appalachian Folksinging Legend Jean Ritchie." The Institute for Southern Studies. Accessed February 10, 2016. http://www.southernstudies.org/2015/06/remembering-appalachian-folksinging-legendjean-ri.html.

This online article contains several anecdotes about Ritchie's life, including references to a song that was nearly stolen by Bob Dylan, as well as her original compositions, including "Blue 
Diamond Mines." A video link to a performance by Ritchie and her sons is also embedded in the article.

Feintuch, Burt. Kentucky Folkmusic: An Annotated Bibliography. Lexington: The University Press of Kentucky. 1985.

With numbered annotations, this book is organized by collections, performers, and other pertinent classifications. Discographies and indexes of authors and subjects follow. The listings for Ritchie include songs in periodicals, her speeches, and her books, as well as works about her family.

“Jean Ritchie Discography.” Discogs. Accessed February 3, 2016. http://www.discogs.com/artist/476000-Jean-Ritchie.

This website provides a lengthy listing of the recordings of Jean Ritchie. It is in the format of a "wiki," however, and must be used with caution as it may not be definitive.

Krassen, Miles. Appalachian Fiddle. New York: Oak Publications, 1973.

This volume of traditional Southern Appalachian fiddle tunes, collected from a number of fiddlers, is a great tune resource. It serves as a primer for the beginning fiddler. There are multiple arrangements of varying difficulty of familiar tunes like "Soldier's Joy." In a formal recital featuring traditional mountain music like that of Jean Ritchie, a collection of these tunes would be most welcome as bookends to the recital or as a transitional interlude to another genre.

Lawless, Ray McKinley. Folksingers and Folksongs in America; a Handbook of Biography, Bibliography, and Discography. New York: Duell, Sloan and Pearce, 1965.

The title gives an accurate description of the contents of this outstanding reference book which is full of articles about the greatest folksingers in American history (up to 1965). Lawless has gone to great lengths to include tidbits of history that I haven't found elsewhere. For example, I now know that Jean Ritchie and new husband George Pickow went on a trip in 1951 to the North Carolina coast. While on the trip, they recorded several folksingers whose recordings are now in the Library of Congress. Lawless also includes indexes of LPs and periodicals on the subject of folk songs and singers. 
Music Tree Artist Management. "Jean Ritchie Discography.” Accessed February 3, 2016. http://www.music-tree.com/ritchiedisco.html.

This website is the Jean Ritchie promotional site that was used by her management company for bookings up until the time of her debilitating stroke in December of 2009. The page contains a bibliography of all of her books, as well as articles that she wrote and articles by others that would pertain to the subject of her work. It does not contain a listing of sound recordings. The discography contains annotations and anecdotes, both by the editor and by Ritchie, herself. It is not a complete discography.

Miller, Terry E. Folk Music in America: A Reference Guide. New York: Garland, 1986.

With references to three of Ritchie's publications, this annotated bibliography is a great "jumping off place" to find more resources on American folk music. Organized by genre, including Native American, psalmody and hymnody, and the shape-note tradition, it contains a wealth of material for further research and study.

Niles, John Jacob. The Ballad Book of John Jacob Niles. New York: Bramhall House, 1960.

This important collection by Niles belongs in a bibliography which is devoting itself to the folk music of the Southern Appalachians. With extensive notes about each ballad, Niles gives a careful documentation of each tune, using his own cataloging system. A simple piano accompaniment with guitar chords notated is listed for each song. A bibliography with indexes of first lines, titles, and additional material is included.

Seven Kentucky Mountain Songs. New York: Schirmer, 1928. Score.

Niles has collected and arranged these seven songs for singer with piano accompaniment. Niles has made these folk songs accessible for formal recital and includes anecdotes about the people from whom he learned them. Cross-referencing Niles' work with Ritchie's work could be very valuable when compiling research for a lecture-recital.

Pen, Ron. "Ritchie, Jean." Grove Music Online, Oxford Music Online. Oxford University Press. Accessed April 17, 2016. http://www.oxfordmusiconline.com/subscriber/article/grove/music/A2263055.

Oxford Online's article on Ritchie's life and works contains a brief reference list for further study as well as another reference to 'Than Hall, the pseudonym under which Ritchie published many of her most iconic original songs. 
Ritchie, Jean. Celebration of Life: Her songs, Her poems. Port Washington, NY: Geordie Music, 1971.

Probably the most important entry in this bibliography, Celebration of Life is a valuable collection of Ritchie's creative work. It includes anecdotes, poems, photographs, and lead sheets to her original songs and arrangements. Some of the songs are composed by Jean Ritchie and some by 'Than Hall. All of the lead sheets include guitar chords and some expressive text. The volume is a wealth of material to use in a formal or informal recital of the music of Jean Ritchie.

Ritchie, Jean. The Dulcimer Book. New York: Oak Publications, 1963.

This book is the definitive textbook for playing Appalachian "mountain" dulcimer. Containing an alphabetical index which lists the church modes used to harmonize each tune, Ritchie has created a songbook that is immediately accessible to a mountain dulcimer player. Each song contains a lead sheet with fingerings, tunings, photographs, explanations, and alternative tunings. A selected discography and bibliography of dulcimer music is listed in the final pages, as well as a listing of books and recordings of Jean Ritchie up to the publication date.

Ritchie, Jean. Folk Songs of the Southern Appalachians. $2^{\text {nd }}$ Edition. Lexington, KY: University Press of Kentucky, 1997.

Containing forwards by folk scholars Allen Lomax and Ron Pen, this songbook is a definitive collection of the folk songs of the Southeastern U.S. Ritchie pens an annotation or an anecdote to each song, attributing it to various relatives, not the least of which was her uncle Jason Ritchie, a lawyer and "song hunter" who had a major influence on her interest in family history and song collection. A selected audiography and videography appears in the final pages of the book, and she includes an index to the songs, including references to their original sources.

Ritchie, Jean. Jean Ritchie's Dulcimer People. New York: Oak Publications, 1975.

A follow-up to The Dulcimer Book, Ritchie uses photographs and text to describe how the mountain dulcimer is used throughout the world in a variety of settings. She includes biographies of dulcimer makers, including husband, George Pickow's uncle Morris Pickow. Lead sheets with fingerings and various tuning instructions are also included. 
Ritchie, Jean. "The L\&N Don't Stop Here Anymore" In Sing Out! the Folk Song Magazine, 44, 108-109. Accessed March 16, 2016. http://navigatoriup.passhe.edu/login?url=http://search.proquest.com.proxyiup.klnpa.org/docview/1203651?accountid=11652.

A brief description of the aforementioned song, this is one of the few places that references "Than Hall" as Jean Ritchie's pseudonym before her compositions became popular. The article prints the entire text of the song.

Ritchie, Jean, ed. The Newport Folk Festival Songbook. New York: Alfred Music, 1965. Song anthology.

As editor of this song anthology, Ritchie has written introductions for each of the included songs which feature performers from the 1963 and 1964 Newport Folk Festivals. Songs from performers such as Bessie Jones, Alan Lomax, and Johnny Cash are included. Of particular interest are original traditional folk song arrangements by Ritchie and her sister Edna.

Ritchie, Jean. None But One. Chicago: Greenhays. 1981. 33 1/3 rpm.

With titles such as "Fair Nottamun Town," "Wondrous Love," and also "None but One," "Black Waters," and "See that Rainbow Shine," Ritchie combines her own compositions with the collected folk songs of her Appalachian and British Isles heritage to create a montage of the connectedness of all peoples. Her insightful anecdotes on the sleeve express this "one-ness" of the human experience. Of the songs on the LP, "None but One" is my favorite. It is a simple tune that could have come from one of many different cultural backgrounds. The song fades into an instrumental "jam" at the end that is reminiscent of the songs made popular by bands such as The Grateful Dead in the 1970s.

Ritchie, Jean. Singing Family of the Cumberlands. Lexington: University of Kentucky Press, 1988.

First published in 1955, this autobiography is a charming account of Jean Ritchie's family life through age 16. It chronicles stories of her grandparents and great-grandparents, her brothers and sisters, and the simple life of Viper, Kentucky, in the early $20^{\text {th }}$ century. The book is liberally sprinkled with the simple melodies and verses of the folk songs the Ritchie family grew up singing and sharing. 
Ritchie, Jean and Doc Watson. Jean Ritchie and Doc Watson at Folk City. New York:

Folkways Records, 1963. 33 1/3 rpm.

Engineered by none other than Peter Bartok, this classic live recording of Ritchie and Doc Watson is a treasure of early Appalachian folk songs and traditional instrumentation. Ritchie pens the liner notes to her own performances while brief quotes from Doc Watson introduce his tunes. Once again, Ritchie recalls anecdotes from her childhood and the family members who shared these songs with her.

Sharp, Cecil J. American-English Folksongs from the Southern Appalachian Mountains. New York: G. Schirmer, 1918.

Cecil Sharp arranged these lovely ballads for piano and voice, chosen from the thousands that he collected from the folksingers who made their homes and livelihoods in the Southern Appalachians. A humble introduction including suggestions for performance practices precedes this collection, which could easily be used in recital today.

Sharp, Cecil J. English Folksongs from the Southern Appalachians. London: Oxford University Press, 1960.

One of the most definitive collections of folksongs from the Southern Appalachians, Sharp divides this volume into ballads, songs, hymns, nursery songs, jigs, and play-party games. Notes and a bibliography are included, as well as an index of titles. Sharp was the first to "discover" Ritchie's family and their knowledge of English ballads. He collected songs from Ritchie's family members as he traveled through the Appalachians in the early $20^{\text {th }}$ century.

Stone, Ruth M. Let the Inside Be Sweet: The Interpretation of Music Event among the Kpelle of Liberia. Bloomington, IN: Trickster Press, 2010.

Indiana University professor Ruth M. Stone discusses the creation of a "music event" to bind together a society. Discussing the social interactions within the Kpelle peoples, she bridges a gap between "formal" performance and the music of the people. This has strong implications when re-interpreting American folk music and its performance in the formal arena.

“'Than Hall Discography.” Discogs. Accessed February 10, 2016. http://www.discogs.com/artist/978779-Than-Hall.

This is brief listing of arrangements and compositions attributed to 'Than Hall, a.k.a. Jean Ritchie, including "The L and N Don't Stop Here Anymore" and "Let the Sun Shine Down on Me." 
Wikipedia. "Jean Ritchie.” Wikipedia Foundation. Updated January 14, 2016. Accessed

February 10, 2016. https://en.wikipedia.org/wiki/Jean_Ritchie.

The Jean Ritchie Wikipedia website documents a comprehensive biography of Ritchie's life, including a discography and bibliography. A number of external links and reference sources lead to more information on her life and works. Of interest in the article is a comment that Ritchie used the masculine pseudonym, 'Than Hall, in order to write controversial songs about the mining industry. Mention is made of her original song entitled, "My Dear Companion."

Wilentz, Sean, and Greil Marcus, ed. The Rose and the Briar: Death, Love and Liberty in the American Ballad. New York: W.W. Norton, 2005.

While not specifically a tome that deals with this topic, a picture of Ritchie's cultural background can be seen in the descriptions of the meanings of the many old "American" ballads outlined in this book. Ritchie is mentioned in the notes on three traditional ballads: "Barbry Ellen," "The Water is Wide," and "Oh, Love is Teasing." In these, it is noted that her interpretation is perhaps the best and communicates the intense emotion in loss of innocence.

Wenner, Hilda E., and Elizabeth Freilicher. Here's to the Women: 100 Songs for and about American Women. New York: The Feminist Press, 1987. Song anthology.

Not only does this book contain a biography of Jean Ritchie and the lead sheet of "Black Waters," it also contains an excellent bibliography of resources for further songs, both recordings and scores, by women composers.

Winick, Stephen. “Jean Ritchie (1922 -2015).” Folk Music Journal, January 2016. 117-119, Music Index, EBSCOhost. Accessed April 16, 2016. http://eds.b.ebscohost.com.proxyiup.klnpa.org/ehost/pdfviewer/pdfviewer?vid=4\&sid=90a8eb82-0e04-45e3-a549dcb5092e1533\%40sessionmgr107\&hid=117.

I have chosen this beautiful obituary in part because the author is an acquaintance through my friends at the Maryland Renaissance Festival. Besides citing several of Ritchie's books and recordings, Mr. Winick has captured the spirit of her song collecting and sharing. He outlines her teaching, Fulbright work, and performances, and includes a brief anecdote of Cecil Sharp's discovery of her family while tracing the roots of British Isles songs in the Appalachian region. Mr. Winick clearly describes the unsurpassable impact of her life on American and British Isles folk music preservation. 


\section{APPENDIX B}

\section{Criteria for Assessing Folk-song to perform as Art-song \\ Example 1}

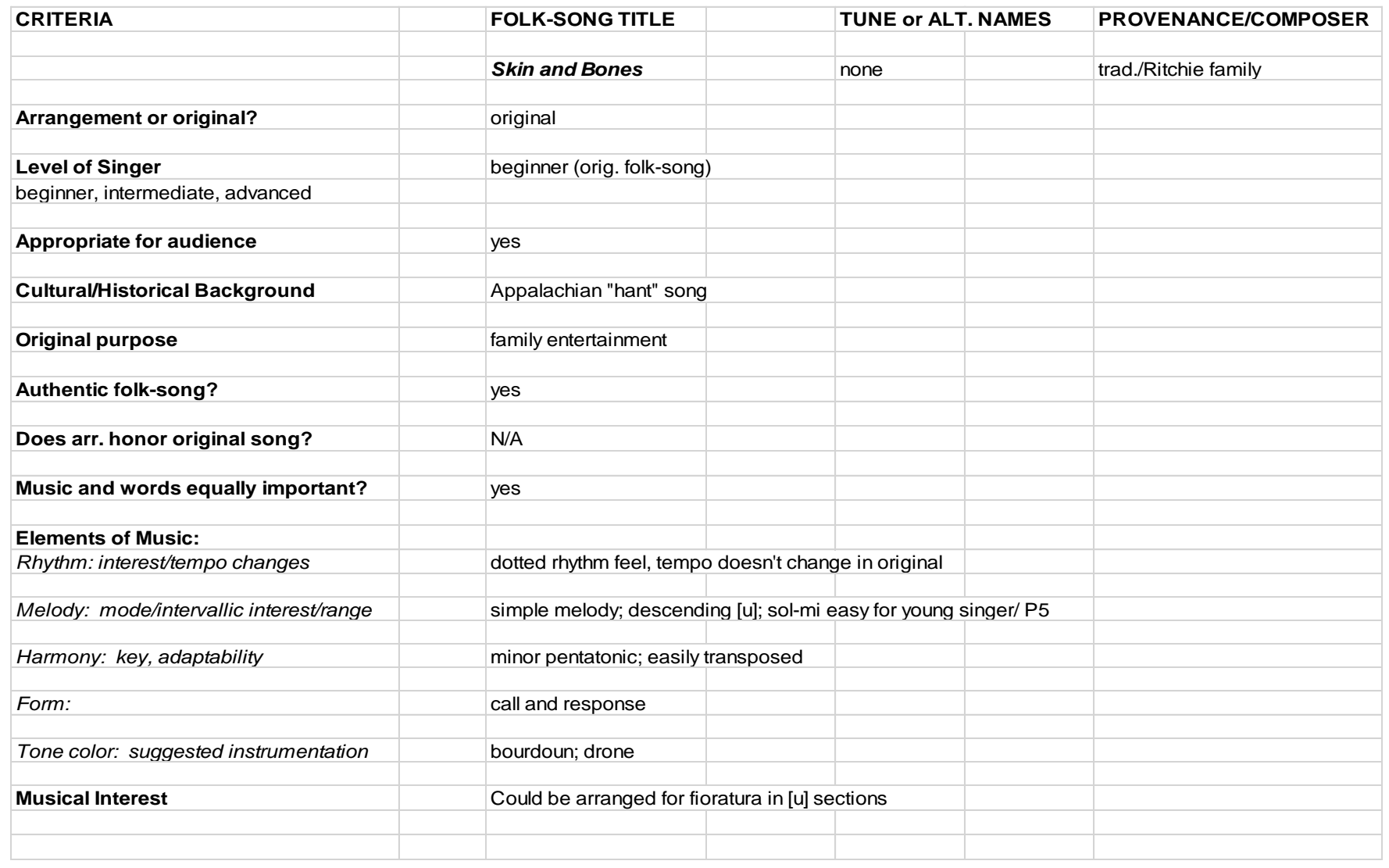




\section{Criteria for Assessing Folk-song to perform as Art-song}

\section{Example 2}

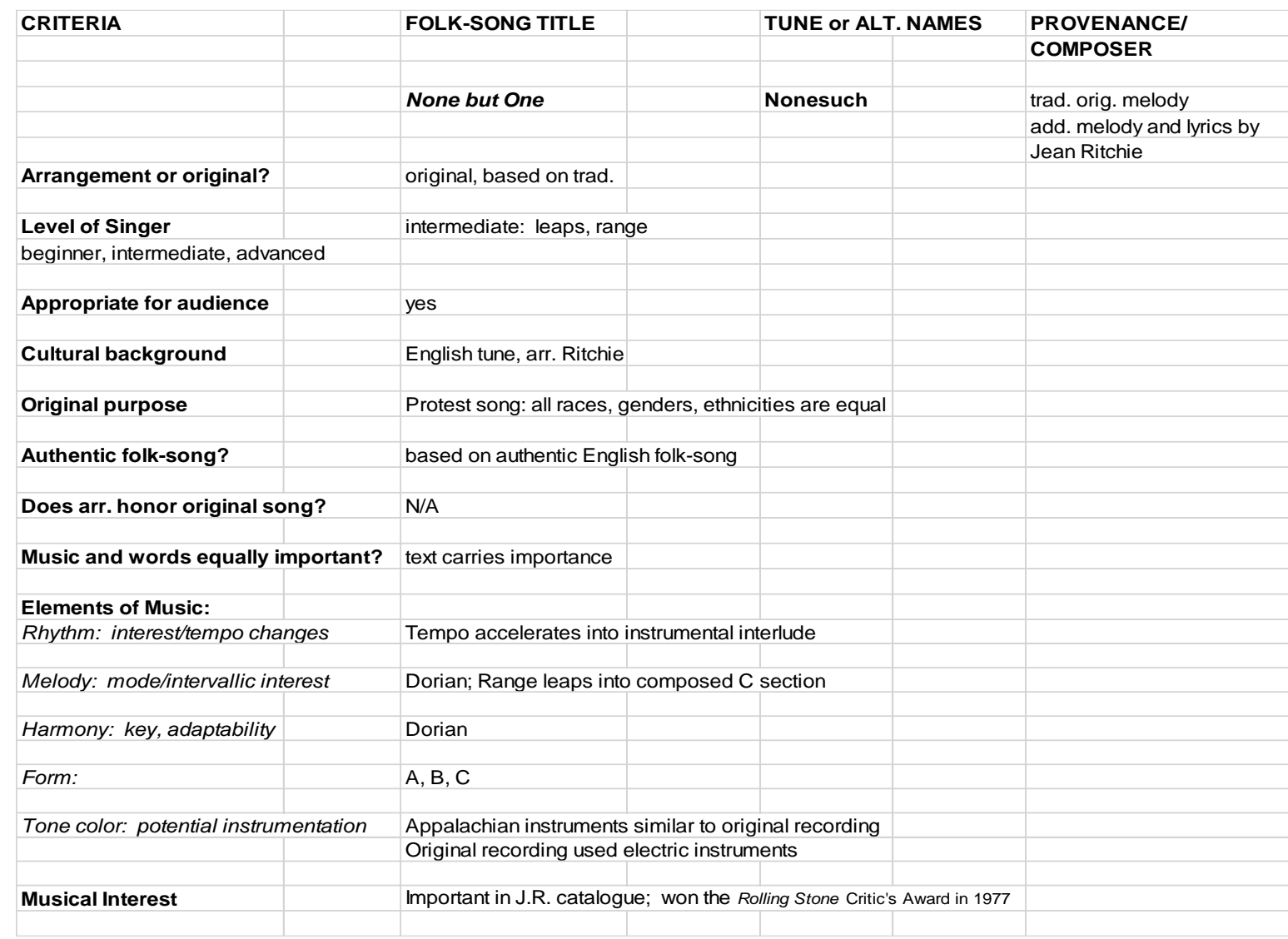




\section{APPENDIX C}

\section{Working organizational chart of songs that met criteria for recital}

\begin{tabular}{|c|c|c|c|c|c|}
\hline Section/Song Title & Provenance/Comp. & Tune or Alt. title & Recording & Lead Sheet & Musical interest \\
\hline \multicolumn{6}{|l|}{ Appalachian Folk Ballads } \\
\hline Come all you Fair and Tender Ladies & trad/Ritchie family & & https://www.youtube.com/watch?v=h1JhPX2M6nY & Folk Songs, 24 & leaps/range/modt \\
\hline Lord Bateman (The Turkish Lady) & trad/Ritchie family & The Turkish Lady & https://www.youtube.com/watch?v=WXWpSbK6rGA\&t=7 & Folk Songs, 28 & story - leaps \\
\hline Barb'ry Ellen & trad/Ritchie family & & https://www. youtube.com/watch?v=913VePGR-QA & Folk Songs, 79 & many arr. \\
\hline \multicolumn{6}{|l|}{ Off the Ritchie Family Porch } \\
\hline Skin and Bones & trad/Ritchie family & & https://www.youtube.com/watch?v=33psNbE Lx8 & Singing Fam. 11 & {$[u]$ response } \\
\hline The Cuckoo & trad/Ritchie family & & https://www.youtube.com/watch?v=5 y- eqmN-A & Folk Songs, 20 & Interesting range \\
\hline Shady Grove & trad/Ritchie family & & https://www.youtube.com/watch?v=pDUNdRm5Toc & Folk Songs, 43 & equated with JR \\
\hline \multicolumn{6}{|l|}{ Appalachian Christmas Songs } \\
\hline The Cherry Tree Carol & trad/Ritchie family & & https://www.youtube.com/watch?v=y7FeXU7PIWc\&t=76s & Folk Songs, 42 & traditional \\
\hline Wintergrace & Jean Ritchie & & https://www.youtube.com/watch?v=zGdQFbv9bfw & unpublished & Mixolydian \\
\hline Brightest and Best & trad/Ritchie family & & https://www.youtube.com/watch?v=5eRcxq9oZSQ & Singing Fam. 150 & hymn tune \\
\hline \multicolumn{6}{|l|}{ Songs about Love } \\
\hline One I Love & Jean Ritchie & & https://www.youtube.com/watch?v=-hSXKhrmSHw & Celeb., 29 & \\
\hline Thousand-Mile Blues & Jean Ritchie & & https://www.youtube.com/watch?v=4hrAUNoXIXE & Celeb., 35 & \\
\hline May Day Day & Jean Ritchie & & https://www.youtube.com/watch?v=V-8gekw3kzw & unpublished & \\
\hline My Dear Companion & trad/Ritchie family & & https://www.youtube.com/watch?v=CBPLbwqvXLU & Folk Songs, 16 & which version? \\
\hline Oh Love is Teasin' Dulcimer & trad/Irish & & https://www.youtube.com/watch?v=QrM5iXZQb5A & Folk Songs, 30 & Interesting Int. \\
\hline Morning come, Maria Gone & Trad./ Jean Ritchie & & https://www.youtube.com/watch?v=V1 KXZ--atk & Celeb., 33 & Mixolydian \\
\hline \multicolumn{6}{|c|}{ Songs of the Carolina coast collected by Jean Ritchie and George Pickow, 1951} \\
\hline \multicolumn{6}{|c|}{ From the Folklife Center at the Library of Congress. } \\
\hline Nell Cropsey and Will Cox & lyric writer unknown & The Wexford Girl & & & \\
\hline When the Booze Yacht Run Ashore & Iyric, Ivey Scott & \multicolumn{2}{|c|}{ East Side, West Side (Lawlor) } & & \\
\hline The Golden Glove & trad. English & \multicolumn{2}{|c|}{ The Squire of Tamsworth } & & \\
\hline The Jolly Cowboy Song & unknown & \multicolumn{2}{|c|}{ When the Work is Done this Fall } & & \\
\hline \multicolumn{6}{|l|}{ Songs about Coal } \\
\hline The L \& N don't stop here anymore & Than Hall & & https://www.youtube.com/watch?v=j6nARSpM-0s & Celeb., 104 & most famous \\
\hline West Virginia Mine Disaster & Jean Ritchie & & https://www.youtube.com/watch?v=wvZwLGmtFY & Celeb., 102 & Mixolydian \\
\hline Black Waters & Jean Ritchie & & https://www.youtube.com/watch?v=Qh3vrD5OCQs \& $\mathrm{t}=13 \mathrm{~s}$ & Celeb., 110 & \\
\hline Blue Diamond Mines & Than Hall & & https://www.youtube.com/watch?v=5oLGXmwMppE & Celeb., 105 & \\
\hline Pay Day at Coal Creek & Jean Ritchie & & https://www.youtube.com/watch?v=zpwT1lcs4C0 & not yet! & Interesting leaps \\
\hline \multicolumn{6}{|l|}{ Songs for Humanity Jean Ritchie } \\
\hline Let the Sun Shine Down & Than Hall & & https://www.youtube.com/watch?v=GdVH9eUL3HY & Celeb., 43 & djembe? \\
\hline None but one & Jean Ritchie & & https://www.youtube.com/watch?v=PrE9hlujcxM & unpublished & layers of sound \\
\hline Peace Round & Jean Ritchie & & https://www.youtube.com/watch?v=FuoTwxE9Ybl & Celeb., 99 & strong message \\
\hline Now is the Cool of the Day & Jean Ritchie & & https://www.youtube.com/watch?v=w46mxx00S0 & & anti nukes \\
\hline \multicolumn{6}{|l|}{ Other songs to consider } \\
\hline The Bluebird Song & Jean Ritchie & & https://www.youtube.com/watch?v=HXilkS0V69Y & & meter change \\
\hline See the Waters A-Gliding (The Nighti & trad/J. Ritchie & & https://www. youtube.com/watch?v=Nyb9JtFiKOY & Celeb., 31 & \\
\hline The Unquiet Grave & trad/Ritchie family & & https://www.youtube.com/watch?v=rQPw $71 \mathrm{Qmfl}$ & Folk Songs, 64 & \\
\hline The Cruel Sea & trad/J. Ritchie & & https://www.youtube.com/watch?v=ds $99 \| I \mathrm{Cl} 3 \mathrm{k}$ & Celeb., 44 & \\
\hline Home to my Dearie & Jean Ritchie & & & Celeb., 59 & sus. line/range \\
\hline The Flowers of Joy & Jean Ritchie & & & Celeb., 67 & major to minor \\
\hline \multirow{2}{*}{\multicolumn{6}{|c|}{$\begin{array}{l}\text { Ritchie, Jean. A Celebration of Life, abbreviated "Celeb" } \\
\text { Ritchie, Jean. Folk Songs of the Southern Appalachians, abbrevated "Folk Songs." }\end{array}$}} \\
\hline \multirow{2}{*}{\multicolumn{3}{|c|}{$\begin{array}{l}\text { Ritchie, Jean. Folk Songs of the Southern Appalachians, abbrevated "Folk Songs." } \\
\text { Ritche, Jean. Singing Famly of the Cumberlands, abbreviated "Singing Fam." }\end{array}$}} & & & \\
\hline & & & & & \\
\hline
\end{tabular}




\section{APPENDIX D}

Recital Program

From Folk-song to Art-song: The Songs of Jean Ritchie (1922 - 2015)

Songs from the Old World and the New: Appalachian Ballads

Collected by Jean Ritchie Come all ye Fair and Tender Ladies

Lord Bateman (The Turkish Lady)

Barbry Ellen

Songs from the Ritchie Family Porch

Skin and Bones

The Cuckoo

Shady Grove

Songs from an Appalachian Christmas

Brightest and Best

Wintergrace

Collected and composed by Jean Ritchie

traditional, arr. R.J. Nestor

Jean Ritchie, arranged by the ensemble

Songs about Love

Oh Love is Teasin'

Morning come, Maria gone

May Day Day

Collected and composed by Jean Ritchie

traditional, arr. R.J. Nestor

traditional with additional text by Jean Ritchie, arranged by the ensemble

Jean Ritchie

Songs of the Carolina Coast

When the Booze Yacht Run Ashore

Nell Cropsey

Collected from Ivey Scott by Jean Ritchie in 1951

text by Ivey Scott and Ralph Sanders, music by Lawlor and Blake text circa 1904, composer unknown, arr. R.J. Nestor

Songs about Coal

Composed by Jean Ritchie

West Virginia Mine Disaster

The L \& N Don't Stop Here Anymore

Jean Ritchie

Songs for Humanity

Let the Sun Shine Down on Me

None but One

Peace Round

Composed by Jean Ritchie Jean Ritchie as 'Than Hall, arranged by J. Laird and R. Jobe Jean Ritchie, arranged by the ensemble

Jean Ritchie
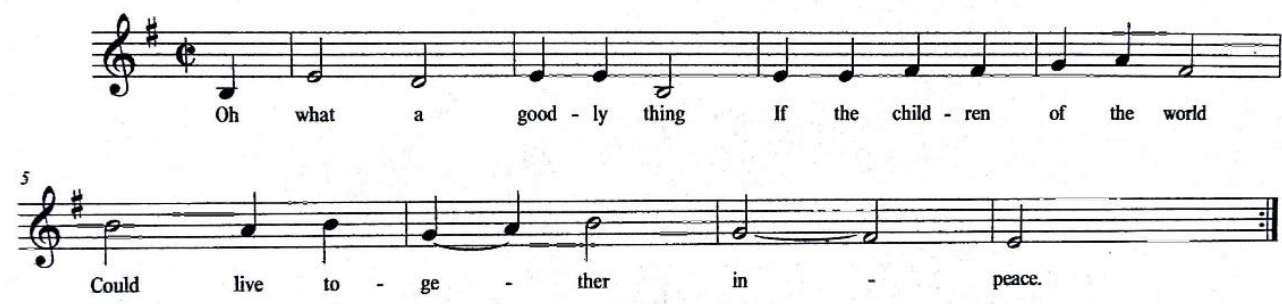


\section{APPENDIX E}

\section{Sample first pages of commissioned arrangements by R.J. Nestor}

\section{Example 1}

\section{Barbry Ellen}
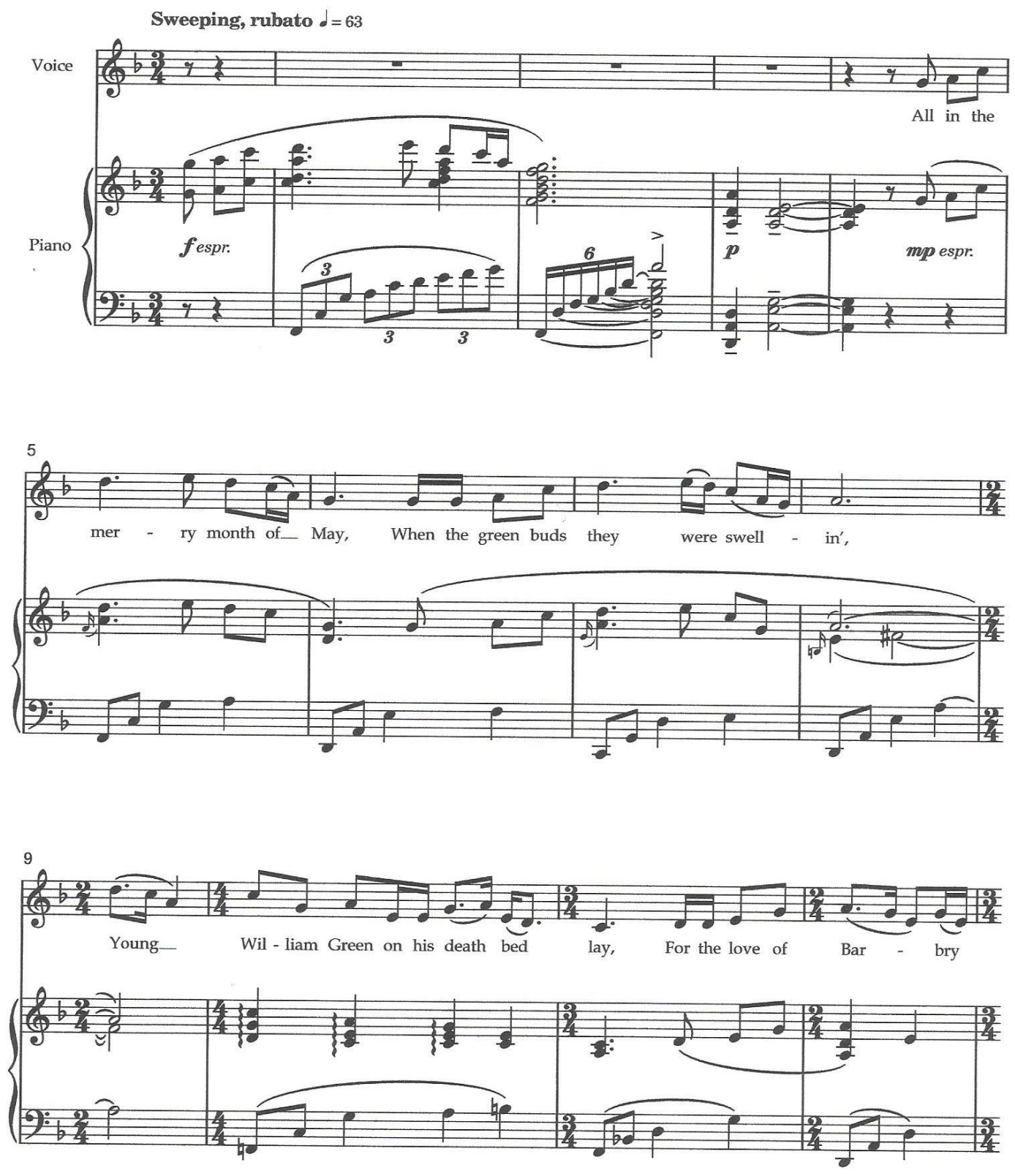


\section{Sample first pages of commissioned arrangements by R.J. Nestor}

\section{Example 2}

Brightest and Best
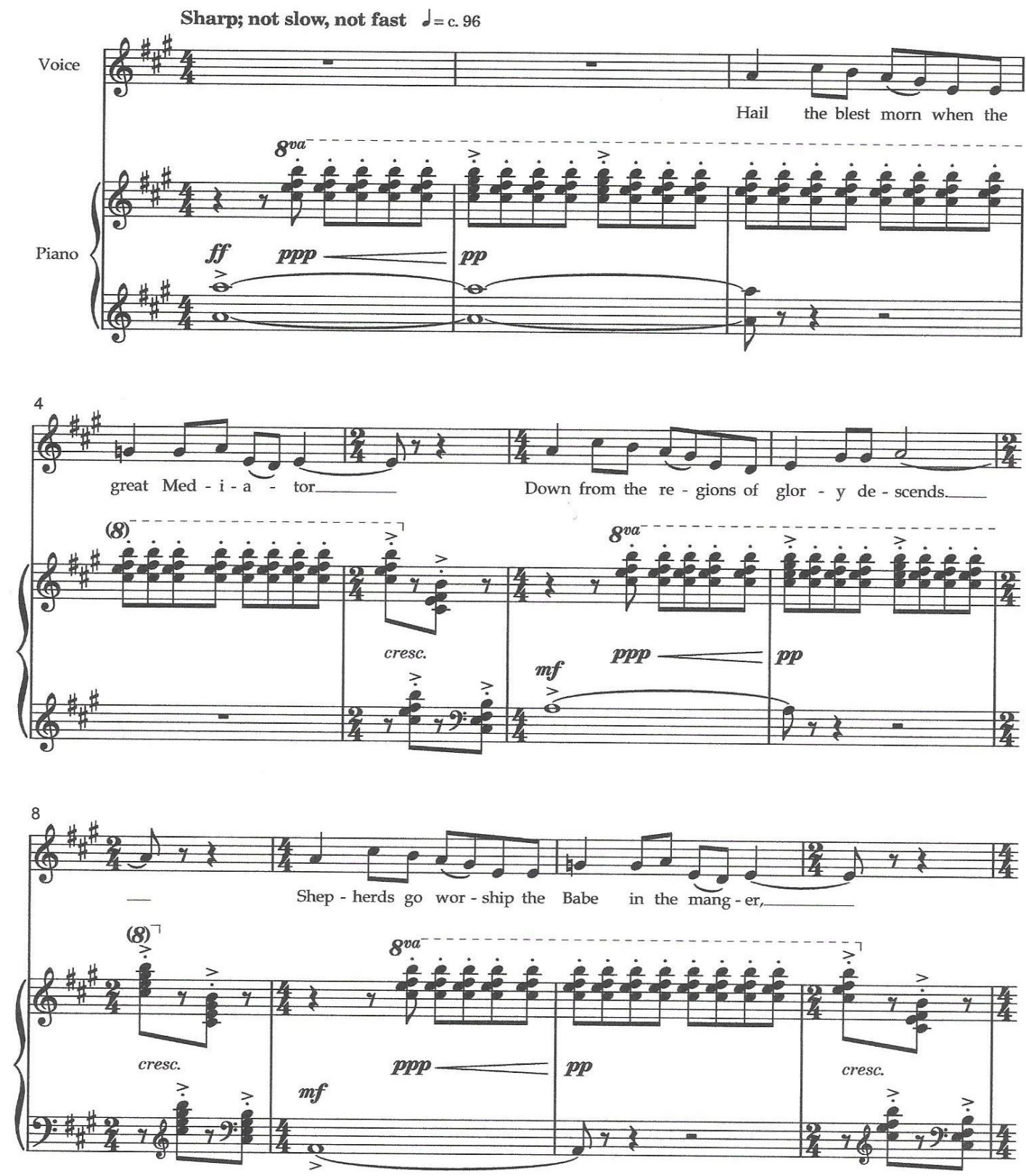